\title{
Nutrients in Ground Water and Surface Water of the United States-An Analysis of Data Through 1992
}

by David K. Mueller, Pixie A. Hamilton, Dennis R. Helsel, Kerie J. Hitt, and Barbara C. Ruddy

\section{U.S. GEOLOGICAL SURVEY}

Water-Resources Investigations Report 95-4031

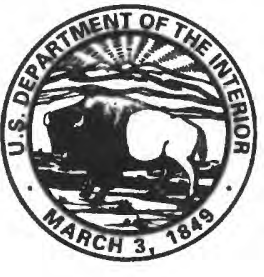




\section{U.S. DEPARTMENT OF THE INTERIOR \\ BRUCE BABBITT, Secretary}

U.S. GEOLOGICAL SURVEY

Gordon P. Eaton, Director

The use of trade, product, industry, or firm names is for descriptive purposes only and does not imply endorsement by the U.S. Government.

For additional information write to:

Copies of this report can be purchased from:

Chief, NAWQA Program

U.S. Geological Survey

12201 Sunrise Valley Drive, MS 413

Reston, VA 22092
U.S. Geological Survey

Earth Science Information Center

Open-File Reports Section

Box 25286, MS 517

Denver Federal Center

Denver, CO 80225

Information regarding the National Water-Quality Assessment (NAWQA) Program is available on the Internet via the World Wide Web. You may connect to the NAWQA Home Page using the Universal Resources Locator (URL) at http://wwwrvares.er.usgs.gov/nawqa/nawqa home.html>. 


\section{FOREWORD}

The mission of the U.S. Geological Survey (USGS) is to assess the quantity and quality of the earth resources of the Nation and to provide information that will assist resource managers and policymakers at Federal, State, and local levels in making sound decisions. Assessment of water-quality conditions and trends is an important part of this overall mission.

One of the greatest challenges faced by waterresources scientists is acquiring reliable information that will guide the use and protection of the Nation's water resources. That challenge is being addressed by Federal, State, interstate, and local water-resource agencies and by many academic institutions. These organizations are collecting water-quality data for a host of purposes that include: compliance with permits and water-supply standards; development of remediation plans for a specific contamination problem; operational decisions on industrial, wastewater, or water-supply facilities; and research on factors that affect water quality. An additional need for water-quality information is to provide a basis on which regional and national-level policy decisions can be based. Wise decisions must be based on sound information. As a society, we need to know whether certain types of water-quality problems are isolated or ubiquitous, whether there are significant differences in conditions among regions, whether the conditions are changing over time, and why these conditions change from place to place and over time. The information can be used to help determine the efficacy of existing. water-quality policies and to help analysts determine the need for and likely consequences of new policies.

To address these needs, the Congress appropriated funds in 1986 for the USGS to begin a pilot program in seven project areas to develop and refine the National Water-Quality Assessment (NAWQA) Program. In 1991, the USGS began full implementation of the program. The NAWQA Program builds upon an existing base of water-quality studies of the USGS, as well as those of other Federal, State, and local agencies. The objectives of the NAWQA Program are to:

- Describe current water-quality conditions for a large part of the Nation's freshwater streams, rivers, and aquifers.
- Describe how water quality is changing over time.

- Improve understanding of the primary natural and human factors that affect water-quality conditions.

This information will help support the development and evaluation of management, regulatory, and monitoring decisions by other Federal, State, and local agencies to protect, use, and enhance water resources.

The goals of the NAWQA Program are being achieved through ongoing and proposed investigations of 60 of the Nation's most important river basins and aquifer systems, which are referred to as study units. These study units are distributed throughout the Nation and cover a diversity of hydrogeologic settings. More than two-thirds of the Nation's freshwater use occurs within the 60 study units and more than two-thirds of the people served by public water-supply systems live within their boundaries.

National synthesis of data analysis, based on aggregation of comparable information obtained from the study units, is a major component of the program. This effort focuses on selected water-quality topics using nationally consistent information. Comparative studies will explain differences and similarities in observed water-quality conditions among study areas and will identify changes and trends and their causes. The first topics addressed by the national synthesis are pesticides, nutrients, volatile organic compounds, and aquatic biology. Discussions on these and other water-quality topics will be published in periodic summaries of the quality of the Nation's ground and surface water as the information becomes available.

This report is an element of the comprehensive body of information developed as part of the NAWQA Program. The program depends heavily on the advice, cooperation, and information from many Federal, State, interstate, Tribal, and local agencies and the public. The assistance and suggestions of all are greatly appreciated. 


\section{CONTENTS}

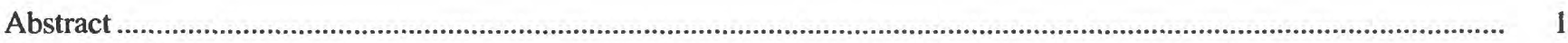

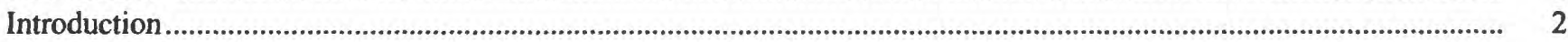

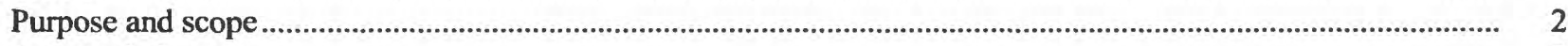

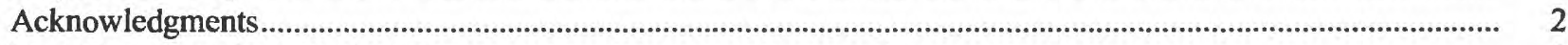

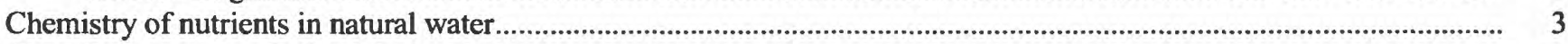

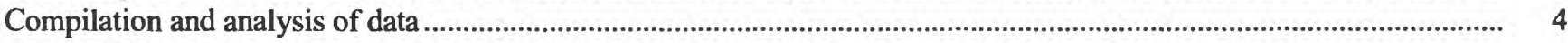

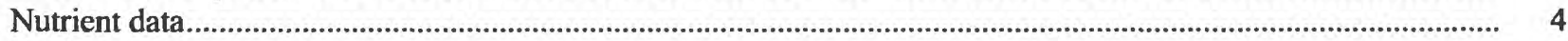

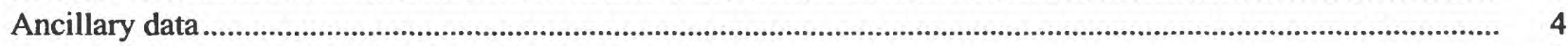

Selection of ground-water data for national analyses ...................................................................................... 11

Selection of surface-water data for national analyses ................................................................................................

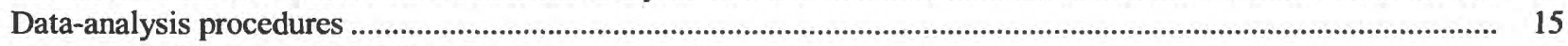

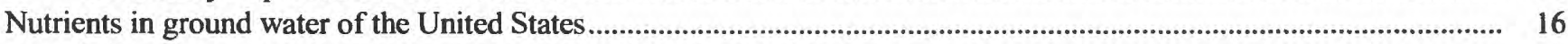

Nitrate concentrations in ground water used for drinking and irrigation........................................................... 16

Factors affecting nitrate concentrations in ground water ...................................................................................... 18

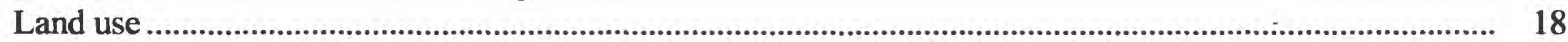

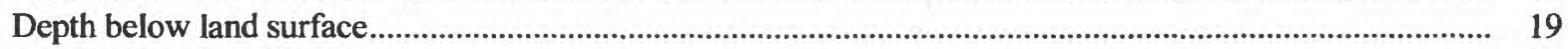

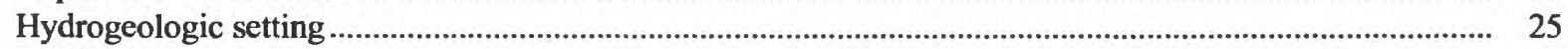

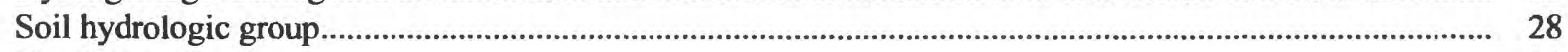

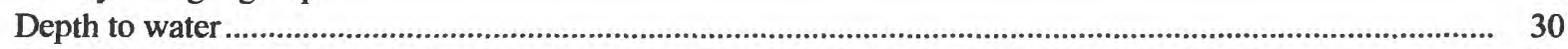

Type of agricultural land use .............................................................................................................. 31

Spatial distribution of nitrate concentrations in ground water beneath agricultural land ......................................... 33

Northeastern States ................................................................................................................................ 33

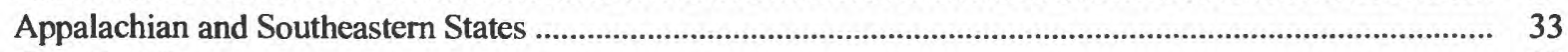

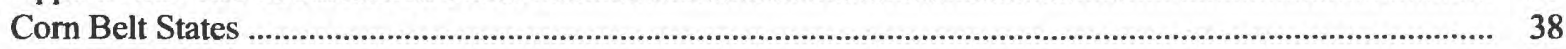

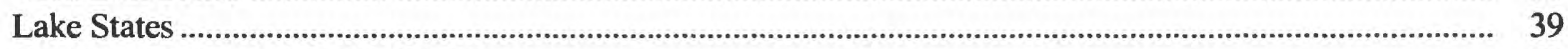

Northern Plains and Pacific States ....................................................................................................... 39

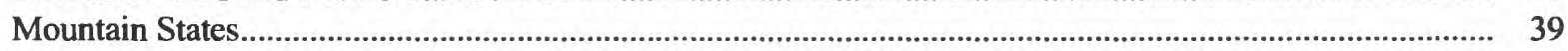

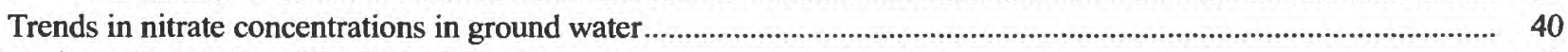

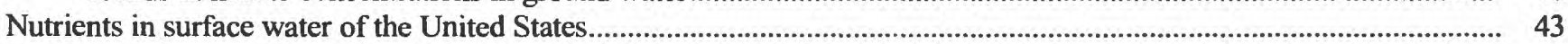

Factors affecting nutrient concentrations in surface water ............................................................................. 44

Drainage from different land uses ........................................................................................................ 44

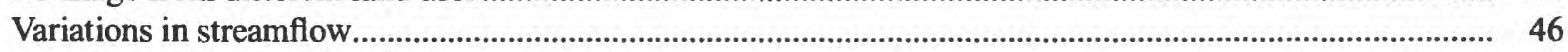

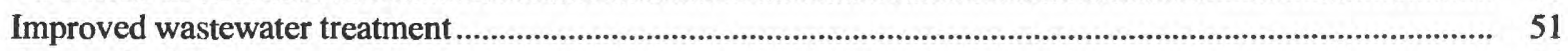

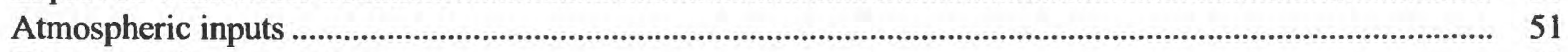

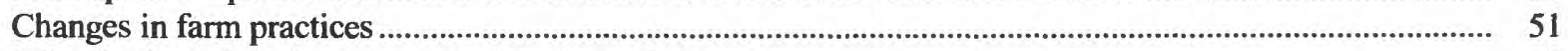

Spatial distribution of nutrient concentrations in surface water ...................................................................... 56

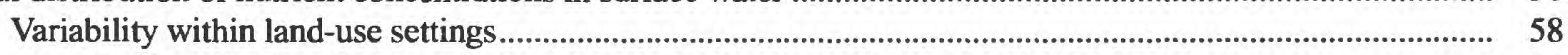

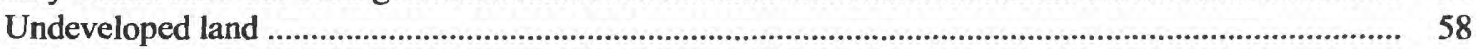

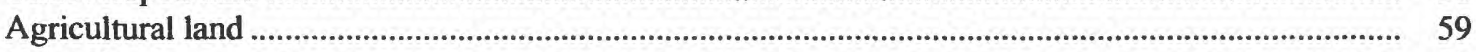

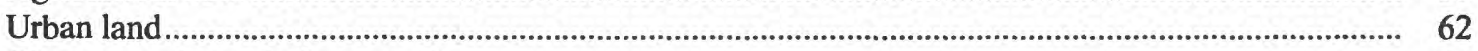

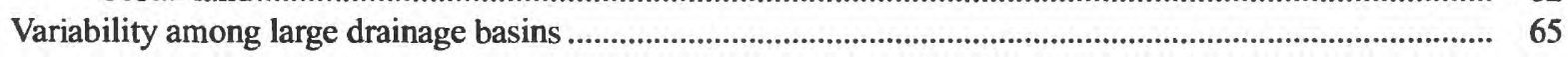

Relation between nitrate concentrations in ground water and surface water in agricultural areas .....................................67

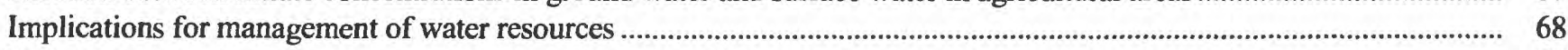

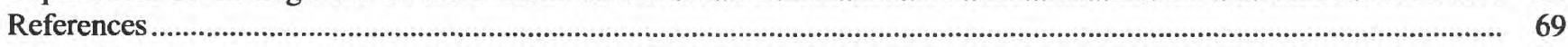

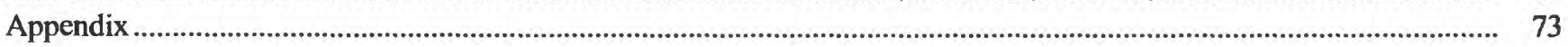




\section{FIGURES}

1. Map showing the location of the first 20 NAWQA study units and 5 other areas from which data were obtained for this report

2. Example diagram and explanation of a boxplot

3. Boxplots showing nitrate concentrations in ground water by type of well use for samples in the national retrospective data set

4. Boxplots showing nitrate concentrations in ground water by type of well use in the Apalachicola-

Chattahoochee-Flint River Basin study unit.

5. Boxplots showing nitrate concentrations in ground water beneath different land-use settings for samples in the national retrospective data set.

6. Map showing NAWQA study units where nitrate concentrations in ground water were significantly higher beneath agricultural areas than beneath undeveloped areas.

7. Boxplots showing nitrate concentrations in ground water beneath different land-use settings in the Connecticut, Housatonic, and Thames River Basins study unit.

8. Graphs showing the relation between nitrate concentrations in ground water and well depth for samples in the national retrospective data set.

9. Map showing NAWQA study units where nitrate concentrations in ground water were related to well depth

10. Boxplots showing nitrate concentrations in ground water from shallow and deep wells in various environmental settings in the Central Nebraska Basins study unit .

1. Graphs showing the relation between nitrite concentrations in ground water and well depth in the Potomac River Basin study unit

12. Boxplots showing nitrate concentrations in ground water beneath agricultural land in different hydrogeologic settings for samples in the national retrospective data set.

13. Map showing NAWQA study units where nitrate concentrations in ground water were related to hydrogeologic setting

14. Boxplots showing nitrate concentrations in ground water for various hydrogeologic settings in the White River Basin study unit

15. Boxplots showing nitrate concentrations in ground water beneath agricultural land in different soil hydrologic groups for samples in the national retrospective data set.

6. Boxplots showing nitrate concentrations in ground water from different areas in the Central

Columbia Plateau study unit

17. Boxplots showing nitrate concentrations in ground water beneath various soil types in the Western Lake Michigan Drainages study unit

18. Graph showing the relation between nitrate concentrations in ground water and depth to water for samples in the national retrospective data set.

9. Boxplots showing nitrate concentrations in ground water from two coastal zones in the AlbemarlePamlico Drainage study unit

20. Boxplots showing nitrate concentrations in ground water beneath agricultural land by incremental ratios of (A) pasture, and (B) woodland on farms to cropland for samples in the national retrospective data set.

21. Map showing geographical regions of the United States

22. Boxplots showing nitrate concentrations in ground water beneath agricultural land by geographical regions of the United States for samples in the national retrospective data set

23. Boxplots showing distributions of (A) soil hydrologic groups, (B) ratios of pasture to cropland, and

(C) ratios of woodland on farms to cropland in different geographical regions of the United States..

24-27. Graphs showing:

24. Trends of nitrate concentrations in ground water from the unconfined Upper Floridan aquifer in agricultural areas in the Georgia-Florida Coastal Plain study unit.

25. Nitrate concentrations in ground water in the central Platte River Valley, Nebraska, during 1974 and 1984

26. Trends of nitrate concentration in ground water from selected wells in the Upper Snake River Basin study unit

27. Trends in annual sales of nitrogen and phosphorus fertilizer sales in the United States... 
28. Map showing NAWQA study units where nitrate concentrations in surface water were significantly

higher downstream from agricultural areas than from undeveloped areas.

29. Boxplots showing concentrations of selected nutrients at surface-water sites in the South Platte

River Basin study unit categorized by upstream land use.

30-33. Graphs showing:

30. Relations between nitrate concentrations and streamflow downstream from forested areas

in the Ozark Plateaus study unit

31. Relation between orthophosphate concentration and streamflow downstream from a wastewater-treatment plant in the Rio Grande Valley study unit

32. Relation between nitrate concentration and streamflow downstream from agricultural return flows in the San Joaquin-Tulare Basins study unit.

33. Relations between nutrient concentrations and streamflow downstream from agricultural areas in (A) the Willamette Basin study unit, and (B) the Lower Susquehanna River Basin study unit.............

34. Map showing NAWQA study units where ammonia concentrations decreased and nitrate concentrations increased in surface water downstream from wastewater-treatment plants

35. Boxplots showing the change in nitrogen speciation for successive time intervals at sites downstream from wastewater-treatment plants in the Trinity River Basin study unit.

36. Graphs showing phosphorus loads in (A) wastewater-treatment plant effluent, and (B) the Chattahoochee River before and after restrictions on the use of phosphate detergents were mandated.

37. Graphs showing trends in nitrate concentration at sites downstream from forested areas in the Hudson

River Basin study unit

38-43. Boxplots showing the:

38. Distributions of ammonia, nitrate, and total phosphorus concentrations in surface water related to upstream land use for samples in the national retrospective data set.

39. Distributions of ammonia, nitrate, and total phosphorus concentrations in surface water draining undeveloped areas in selected NAWQA study units for samples in the national retrospective data set .

40. Distributions of ammonia, nitrate, and total phosphorus concentrations in surface water draining agricultural areas in selected NAWQA study units for samples in the national retrospective data set.

41. Distributions of ammonia, nitrate, and total phosphorus concentrations in surface water draining urban areas in selected NAWQA study units for samples in the national retrospective data set

42. Distributions of ammonia, nitrate, and total phosphorus concentrations in surface water draining large basins in selected NAWQA study units for samples in the national retrospective data set.

43. Distribution of streamflow at the time of sampling at sites downstream from large basins in selected NAWQA study units for samples in the national retrospective data set.

44. Bar chart showing median nitrate concentrations in ground water and surface water from selected NAWQA study units.

\section{TABLES}

1. National Water-Quality Assessment (NAWQA) Program study units and supplemental study areas included in this report

2. Summary of procedures used to aggregate nutrient data into constituent groups .

3. Overview of selected characteristics of National Water-Quality Assessment (NAWQA) Program study units .....

4. Overview of individual ground-water data sets from study units and supplemental study areas included in the national analysis.

5. Overview of selected nutrients in the national retrospective data set for ground water

6. Distribution of surface-water samples by National Water-Quality Assessment (NAWQA) Program study unit.

7. Distribution of surface-water samples by dominant upstream land use 
8-15. Summary of nitrate concentrations:

8. In ground water by well type

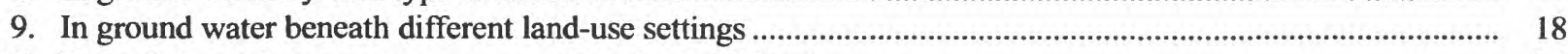

10. By well depth in ground water beneath agricultural land ...................................................................... 21

11. By hydrogeologic setting in ground water beneath agricultural land ...................................................... 25

12. By soil hydrologic group in ground water beneath agricultural land ........................................................ 28

13. By depth to water in ground water beneath agricultural land ................................................................. 30

14. By ratio of pasture or woodland on farms to cropland in ground water beneath agricultural land .................. 32

15. By geographic region in ground water beneath agricultural land ............................................................

16. National Water-Quality Assessment (NAWQA) Program study units used in national comparisons within various land-use categories and among large drainage basins.

17. Spearman correlation coefficients between selected drainage-basin characteristics and nutrient concentrations at sites downstream from agricultural land use

\section{CONVERSION FACTORS}

\begin{tabular}{rll}
\hline Multiply & By & To obtain \\
\hline & & \\
cubic foot per second $\left(\mathrm{ft}^{3} / \mathrm{s}\right)$ & 0.028317 & cubic meter per second \\
foot $(\mathrm{ft})$ & 0.3048 & meter \\
gallon $(\mathrm{gal})$ & 3.785 & liter $(\mathrm{L})$ \\
inch & 25.4 & millimeter \\
square mile $_{\left(\mathrm{mi}^{2}\right)}$ & 2.590 & square kilometer \\
ton & 0.907185 & metric ton \\
\hline
\end{tabular}

Degree Celsius $\left({ }^{\circ} \mathrm{C}\right)$ may be converted to degree Fahrenheit $\left({ }^{\circ} \mathrm{F}\right)$ by using the following equation:

$$
{ }^{\circ} \mathrm{F}=9 / 5\left({ }^{\circ} \mathrm{C}\right)+32 \text {. }
$$

Degree Fahrenheit $\left({ }^{\circ} \mathrm{F}\right)$ may be converted to degree Celsius $\left({ }^{\circ} \mathrm{C}\right)$ by using the following equation:

$$
{ }^{\circ} \mathrm{C}=5 / 9\left({ }^{\circ} \mathrm{F} \ldots 32\right) \text {. }
$$

Milligram per liter $(\mathrm{mg} / \mathrm{L})$, used in this report for constituent concentrations in water, is equivalent to gram per cubic meter and, at typical concentrations in natural waters, to parts per million. 


\title{
Nutrients in Ground Water and Surface Water of the United States-An Analysis Of Data Through 1992
}

\author{
By David K. Mueller, Pixie A. Hamilton, Dennis R. Helsel, Kerie J. Hitt, and Barbara C. Ruddy
}

\section{Abstract}

Historical data on nutrient (nitrogen and phosphorus species) concentrations in groundand surface-water samples were compiled from 20 study units of the National Water-Quality Assessment (NAWQA) Program and 5 supplemental study areas. The resultant national retrospective data sets contained analyses of about 12,000 ground-water and more than 22,000 surface-water samples. These data were interpreted on regional and national scales by relating the distributions of nutrient concentrations to ancillary data, such as land use, soil characteristics, and hydrogeology, provided by local studyunit personnel. The information provided in this report on environmental factors that affect nutrient concentrations in ground and surface water can be used to identify areas of the Nation where the vulnerability to nutrient contamination is greatest.

Nitrate was the nutrient of greatest concern in the historical ground-water data. It is the only nutrient that is regulated by a national drinkingwater standard. Nitrate concentrations were significantly different in ground water affected by various land uses. Concentrations in about 16 percent of the samples collected in agricultural areas exceeded the drinking-water standard. However, the standard was exceeded in only about 1 percent of samples collected from public-supply wells.

A variety of ancillary factors had significant relations to nitrate concentrations in ground water beneath agricultural areas. Concentrations generally were highest within 100 feet of the land surface. They were also higher in areas where soil and geologic characteristics promoted rapid movement of water to the aquifer. Elevated concentrations commonly occurred in areas underlain by permeable materials, such as carbonate bedrock or unconsolidated sand and gravel, and where soils are generally well drained. In areas where water movement is impeded, denitrification might lead to low concentrations of nitrate in the ground water. Low concentrations were also related to interspersion of pasture and woodland with cropland in agricultural areas. Elevated nitrate concentrations in areas of more homogeneous cropland probably were a result of intensive nitrogen fertilizer application on large tracts of land.

Certain regions of the United States seemed more vulnerable to nitrate contamination of ground water in agricultural areas. Regions of greater vulnerability included parts of the Northeast, Midwest, and West Coast. The welldrained soils, typical in these regions, have little capacity to hold water and nutrients; therefore, these soils receive some of the largest applications of fertilizer and irrigation in the Nation. The agricultural land is intensively cultivated for row crops, with little interspersion of pasture and woodland.

Nutrient concentrations in surface water also were generally related to land use. Nitrate concentrations were highest in samples from sites downstream from agricultural or urban areas. However, concentrations were not as high as in ground water and rarely exceeded the drinkingwater standard. Elevated concentrations of nitrate in surface water of the Northeastern United States might be related to large amounts of atmospheric deposition (acid rain). High concentrations in parts of the Midwest might be related to tile drainage of agricultural fields.

Ammonia and phosphorus concentrations were highest downstream from urban areas. These concentrations generally were high enough to warrant concerns about toxicity to fish and accelerated eutrophication. Recent improvements in wastewater treatment have decreased ammonia concentrations downstream from some urban areas, but the result has been an increase in nitrate concentrations. 
Information on environmental factors that affect water quality is useful to identify drainage basins throughout the Nation with the greatest vulnerability for nutrient contamination and to delineate areas where ground-water or surfacewater contamination is most likely to occur. The results presented in this report suggest that the best-management strategies will differ among regional areas of the Nation. Understanding the regional patterns and environmental factors that affect nutrient concentrations in ground water and surface water is critical for designing programs to manage and protect water resources.

\section{INTRODUCTION}

In 1991, the U.S. Geological Survey (USGS) began full implementation of the National WaterQuality Assessment (NAWQA) Program. The objectives of the NAWQA Program are to:

- Describe current water-quality conditions for a large part of the Nation's freshwater streams, rivers, and aquifers.

- Describe how water quality is changing over time.

- Improve understanding of the primary natural and human factors that affect water-quality conditions.

These objectives are being achieved through investigations of 60 of the Nation's most important river basins and aquifer systems, which are referred to as study units. Individual study-unit investigations are coordinated in design and approach to allow regional and national comparisons. Implementation of studyunit investigations are phased so that data are collected in 20 areas at a time.

One of the initial tasks of the study-unit investigations is to review the data previously collected by the USGS and other Federal, State, and local agencies. The results of these retrospective analyses for the first 20 study units have been presented in a series of documents. USGS personnel who may be contacted for additional information on individual study-unit investigations are listed in the Appendix.

\section{Purpose and Scope}

The data interpretation presented in this report is based on nutrient (nitrogen and phosphorus) analyses of ground-water and surface-water samples collected through 1992 within the first 20 NAWQA study units. Therefore, the "national" analyses in this report are limited to 20 large areas, not the entire land surface of the Nation. Although the results will undoubtedly improve as the NAWQA Program increases in spatial coverage, the range of conditions in the first 20 study units is sufficiently diverse to warrant consideration of these analyses as national in scope.

This report describes broad regional and national patterns in nutrient concentrations, putting results of local investigations into a larger perspective, as well as showing influences that affect nutrient concentrations consistently at locations throughout the Nation. In addition to discussion of the national data analyses, examples of the same patterns at local scales are presented from the analyses reported for individual study units. Nutrients were selected for this synthesis because they have been a long-standing national water-quality issue and were identified as a local issue by water managers within each of the 20 study units.

\section{Acknowledgments}

The analyses and results presented in this report would not have been achievable without the diligent efforts of many staff members of the 20 NAWQA study units. In addition to compiling the study-unit data that were included in the national data sets and reporting data interpretations at the local study-unit level, these people responded to numerous special requests for more information, for aid in analyzing data at the regional or national level, and for review of our interpretations. Results of the study-unit retrospective analyses are referenced throughout this report. Numerous figures from study-unit documents are reproduced as local examples of patterns identified in the national data. All of the study-unit retrospective reports that were approved for publication at the time this report was prepared have been included in the References section. Several other draft documents were helpful in accomplishing our work. The primary authors of retrospective reports in each study unit are listed in the Appendix. We owe these people a tremendous debt of gratitude.

We also thank David Eckhardt and Patrick Phillips of the USGS, New York District, for their insightful technical reviews of the draft report. Their comments contributed to significant improvements in the final text. 


\section{CHEMISTRY OF NUTRIENTS IN NATURAL WATER}

Nitrogen and phosphorus are important elements in plant and animal nutrition. Both elements occur in a variety of forms (chemical species). Both are affected by chemical and biological processes that can change their form and can transfer them to or from the lithosphere, atmosphere, hydrosphere, or biosphere.

In natural water, nitrogen occurs primarily as ammonium $\left(\mathrm{NH}_{4}{ }^{+}\right)$, nitrite $\left(\mathrm{NO}_{2}{ }^{-}\right)$, and nitrate $\left(\mathrm{NO}_{3}{ }^{-}\right)$, and as a component of some organic solutes and particulates (Hem, 1985, p. 124-126). Un-ionized ammonia $\left(\mathrm{NH}_{3}\right)$ also exists, in equilibrium with ammonium.

This equilibrium is influenced by $\mathrm{pH}$ and temperature; below a $\mathrm{pH}$ of about 9.2, most of the ammonia nitrogen is ionic $\left(\mathrm{NH}_{4}^{+}\right)$.

Ammonium and un-ionized ammonia are soluble in water but are easily oxidized to nitrite. Ammonium adsorbs to mineral surfaces and can be transported by erosion and sediment movement. Nitrite is an intermediate form in the transformation of ammonium to nitrate (nitrification), or in the transformation of nitrate to nitrogen gas (denitrification), and occurs in significant concentrations only in the immediate vicinity of sewage or other organic-waste disposal. Nitrate is highly soluble in water and is stable over a wide range of environmental conditions. It is readily transported in ground and surface waters.

The only significant form of dissolved phosphorus in natural water is phosphate, including ortho-, pyro-, and polyphosphates (Hem, 1985, p. 126-128). Orthophosphate $\left(\mathrm{PO}_{4}{ }^{3-}\right)$, in various combinations with hydrogen $\left(\mathrm{HPO}_{4}{ }^{2-}, \mathrm{H}_{2} \mathrm{PO}_{4}^{-}\right.$, and $\left.\mathrm{H}_{3} \mathrm{PO}_{4}\right)$, is the most stable form and the one commonly identified in laboratory analyses. Phosphorus also may be abundant in sediment and organic particulates. Phosphates are only moderately soluble and, relative to nitrate, are not very mobile in soils and ground water. However, erosion can transport considerable amounts of suspended phosphorus to surface waters. Biological uptake and adsorption by metal oxides generally limit the concentration of dissolved phosphorus to no more than a few tenths of a milligram per liter in most waters.
Nitrogen and phosphorus are present in sewage and animal waste. Organic nitrogen, ammonia nitrogen, and organic phosphorus are primary metabolic byproducts. Orthophosphate also occurs in sewage as a component of detergents and other cleaning products.

Floating algae and cyanobacteria depend on dissolved, inorganic nitrogen and phosphorus for their nutrient supplies. Anthropogenic sources of these nutrients can accelerate algal production in receiving waters. This process, called eutrophication, can result in a variety of water-quality problems, including clogged pipelines, fishkills, and restricted recreation.

Nitrate is the only nutrient for which the U.S. Environmental Protection Agency (USEPA) has established a maximum contaminant level (MCL) in drinking water $(10 \mathrm{mg} / \mathrm{L}$; U.S. Environmental Protection Agency, 1990b). Nitrate can be converted to nitrite in the gastrointestinal tract, and nitrite will tie up some of the blood's supply of hemoglobin as methemoglobin. Infants lack the enzyme necessary to reduce methemoglobin back to oxyhemoglobin until around 4 months of age, and so may be unable to transport sufficient oxygen in their bloodstream. Fatalities from "blue baby syndrome," or methemoglobinemia, occur each year and are most common in rural areas (Johnson and Kross, 1990). Illness and death caused by methemoglobinemia may not be accurately recognized and its occurrence underreported. Although one case in Colorado was attributed to infant formula made from public-supply water that had a nitrate concentration of $13.3 \mathrm{mg} / \mathrm{L}$, most cases involve concentrations that are somewhat higher (Fan and others, 1987). In parts of Eastern Europe where ground water is contaminated with $50-100 \mathrm{mg} / \mathrm{L}$ nitrate, pregnant women and mothers are supplied bottled water until their children reach 1 year of age.

The USEPA also has established criteria for maximum ammonia concentrations in surface water based on chronic and acute exposure of aquatic organisms to un-ionized ammonia (U.S. Environmental Protection Agency, 1986). These criteria vary with $\mathrm{pH}$ and temperature, which affect both the toxicity of un-ionized ammonia and the equilibrium between unionized ammonia and the ammonium ion. Within the ranges of $\mathrm{pH}(6.5-9.0)$ and temperature $\left(0-30^{\circ} \mathrm{C}\right)$ for most natural surface waters, total ammonia $\left(\mathrm{NH}_{3}\right.$ plus $\mathrm{NH}_{4}^{+}$) concentrations greater than about $2.1 \mathrm{mg} / \mathrm{L}$ (as $\mathrm{N}$ ) exceed the chronic criteria. At high $\mathrm{pH}$ (about 9.0) and temperature (about $30^{\circ} \mathrm{C}$ ), the criteria can be exceeded by total ammonia concentrations as low as $0.07 \mathrm{mg} / \mathrm{L}$. 
No national criteria have been established for concentrations of phosphorus compounds in water; however, to control eutrophication, the USEPA (U.S. Environmental Protection Agency, 1986) makes the following recommendations:

- Total phosphates should not exceed $0.05 \mathrm{mg} / \mathrm{L}$ (as P) in a stream at a point where it enters a lake or reservoir.

- Total phosphorus should not exceed $0.1 \mathrm{mg} / \mathrm{L}$ in flowing waters that do not discharge directly into lakes or impoundments.

\section{COMPILATION AND ANALYSIS OF DATA}

This report presents an analysis of existing water-quality data collected before initiation of sampling in 1993 by the first 20 NAWQA study units. It is, therefore, a retrospective analysis, intended to determine the preexisting water-quality conditions in the NAWQA study units. Water-quality data were obtained by study-unit personnel from the USGS National Water Information System (NWIS) and from the USEPA national data base, STORET. Ancillary data describing characteristics of the water-quality sampling sites were obtained from NAWQA study-unit compilations and from national-scale digital maps.

\section{Nutrient Data}

The data for retrospective analysis of waterquality conditions in each NAWQA study unit were obtained by study-unit personnel from historical records. Sites were selected that had adequate samples during the period 1970-92 and that best represented the land uses in the study unit. Data from these sites were assessed for general accuracy and usefulness on the basis of computed ionic charge-balance, outlying values, and information on sampling objectives. Data provided for each study unit were compiled into national retrospective data sets used for the ground-water and surface-water analyses presented in this report. The ground-water data set was supplemented by data from the Delmarva Peninsula NAWQA pilot study area and from four study areas of the USGS Toxic-Substances Hydrology (Toxics) Program. The reader may refer to table 1 and figure 1 for identification and location of the study units and supplemental study areas.

Data objectives and requirements varied for the individual projects that collected the samples included in the national retrospective data sets. In addition, sampling, preservation, and analytical techniques changed during the period of record. Therefore, nutrient concentrations in samples selected for these data sets were analyzed using a variety of methods, and the analytical results were expressed using a variety of reporting conventions. For consistency of national assessment, nutrient constituents were aggregated into the following groups:

- Ammonia as $\mathrm{N}$, including both ammonium ions and un-ionized ammonia (hereinafter referred to as ammonia).

- Nitrate as $\mathrm{N}$ (hereinafter referred to as nitrate).

- Total nitrogen.

- Dissolved orthophosphate as P (hereinafter referred to as orthophosphate).

- Total phosphorus.

The procedures used to combine nutrient data for national analysis of each constituent are presented in table 2. Personnel from some study units provided only data that had been combined using their own procedures, which were not necessarily the same as the national procedures.

\section{Ancillary Data}

Regional and national comparisons of nutrient concentrations in ground and surface waters were based on characteristics of the location of a groundwater sampling well or of the drainage basin upstream from a surface-water sampling site. Characteristics in the ancillary data set included land use, population, aquifer composition, and soil type. Much of the ancillary data was provided by NAWQA study-unit personnel; however, some characteristics were evaluated from national-scale information to maintain consistency among study units. Ancillary data provided for some study units were at a finer resolution but were disregarded in favor of national-scale data. A partial list of ancillary data used in this report is shown in table 3.

Latitude and longitude of the sampling sites were the primary ancillary data used for location of groundwater and surface-water sample collection. In addition, latitude and longitude of surface-water sites were used to define the upstream drainage basin contributing to streamflow at the sites. Depth of the well and depth to water were used to determine the location of groundwater sampling below the land surface. Streamflow at the time of surface-water sampling was used to indicate the hydrologic condition during sample collection. If streamflow was not measured at the time of sampling, the mean daily flow for the date of sampling was used. 
Table 1. National Water-Quality Assessment (NAWQA) Program study units and supplemental study areas included in this report

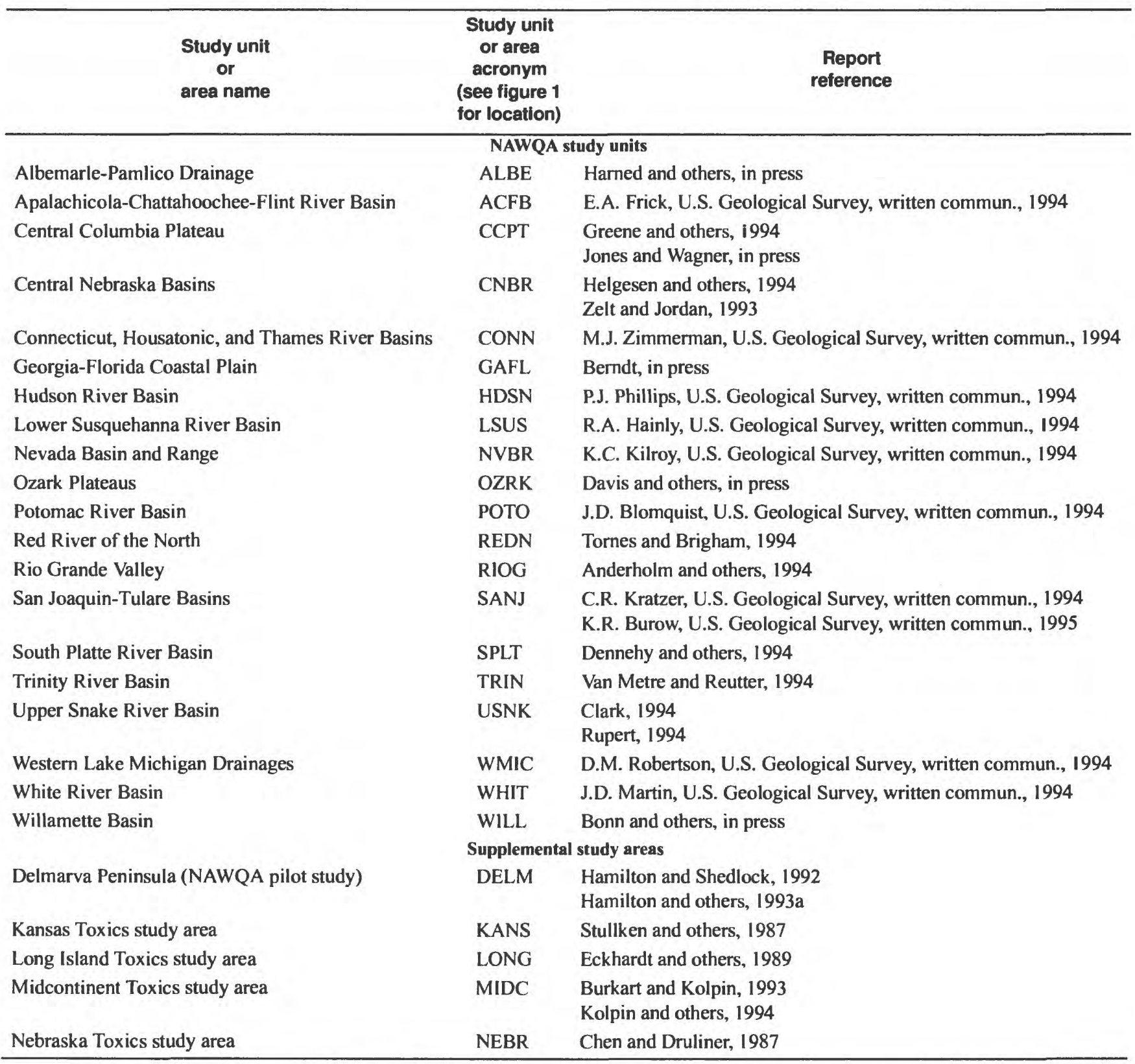




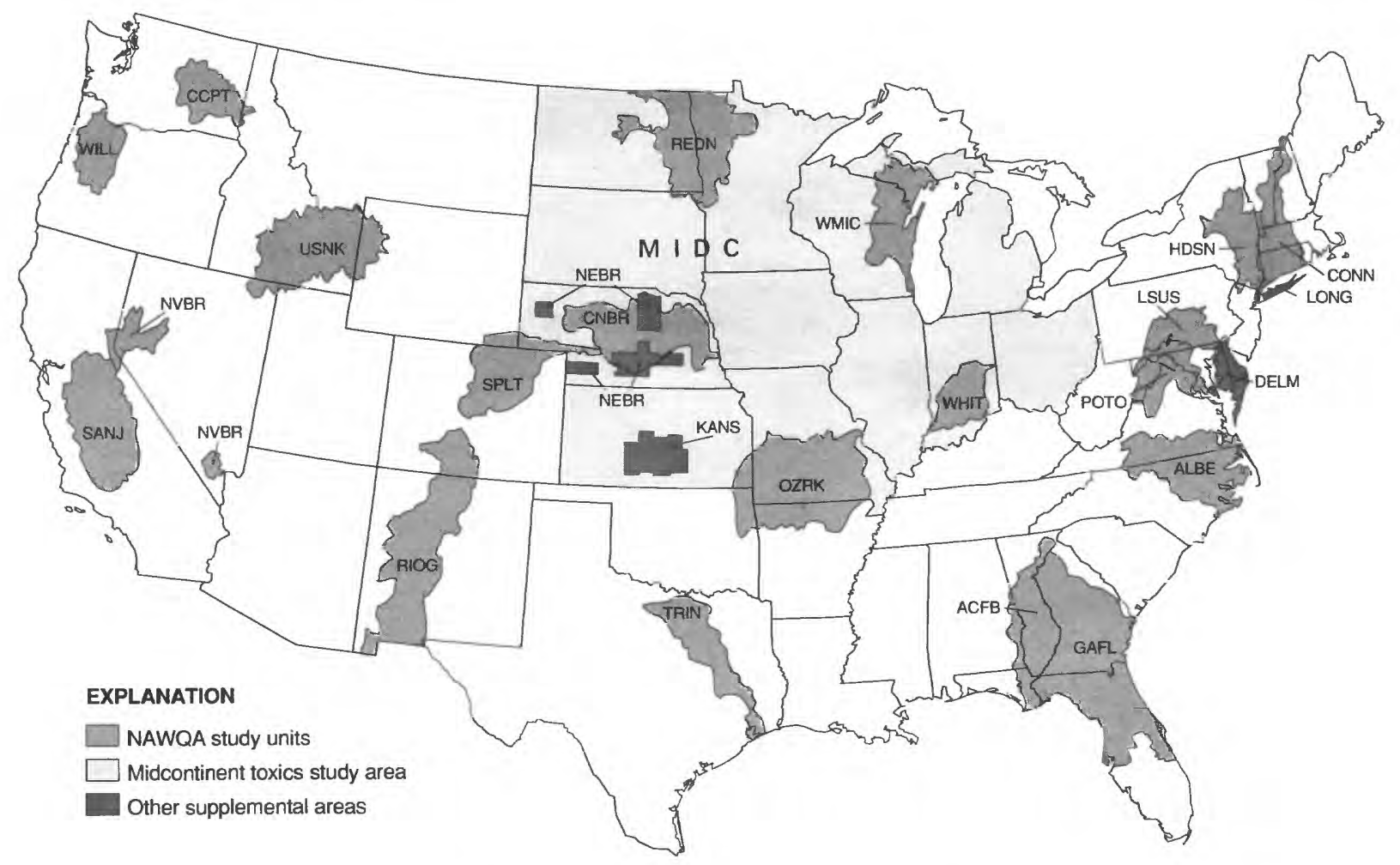

\begin{tabular}{ll}
\hline Map acronym & \multicolumn{1}{c}{ Short name in text } \\
\hline \multicolumn{1}{c}{ NAWQA study units } \\
ALBE & Albemarle-Pamlico \\
ACFB & Apalachicola \\
CCPT & Central Columbia \\
CNBR & Central Nebraska \\
CONN & Connecticut \\
GAFL & Georgia-Florida \\
HDSN & Hudson \\
LSUS & Lower Susquehanna \\
NVBR & Nevada \\
OZRK & Ozark \\
POTO & Potomac \\
REDN & Red \\
RIOG & Rio Grande \\
SANJ & San Joaquin \\
SPLT & South Platte \\
TRIN & Trinity \\
USNK & Upper Snake \\
WMIC & W. Lake Michigan \\
WHIT & White \\
WILL & Willamette \\
Supplemental study areas \\
DELM & Delmarva \\
KANS & Kansas Toxics \\
LONG & Long Island Toxics \\
MIDC & Midcontinent Toxics \\
NEBR & Nebraska Toxics \\
\hline & \\
&
\end{tabular}

Figure 1. Location of the first 20 NAWQA study units and 5 other areas from which data were obtained for this report. 
Table 2. Summary of procedures used to aggregate nutrient data into constituent groups

[mg/L, milligram per liter; $\mathrm{N}$, nitrogen; $\mathrm{NH}_{4}$, ammonium; $\mathrm{NO}_{2}$, nitrite; $\mathrm{NO}_{3}$, nitrate; $\mathrm{P}$, phosphorus; $\mathrm{PO}_{4}$, orthophosphate; *, parameter determined by using the procedure listed for nitrite, as $\mathrm{N}$; **, parameter determined by using the procedure listed for nitrate, as N]

\begin{tabular}{|c|c|c|}
\hline Constituent group & Nutrient data parameter name & Nutrlent data parameter code ${ }^{1}$ \\
\hline \multirow[t]{4}{*}{ Ammonia, as $\mathrm{N}$} & Nitrogen, ammonia, dissolved (mg/L as $\mathrm{N})$ & 00608 \\
\hline & Nitrogen, ammonia, dissolved (mg/L as $\mathrm{NH}_{4}$ ) & 71846 (multiplied by 0.7765 ) \\
\hline & Nitrogen, ammonia, total (mg/L as $\mathrm{N})$ & 00610 \\
\hline & Nitrogen, ammonia, total (mg/L as $\left.\mathrm{NH}_{4}\right)$ & 71845 (multiplied by 0.7765 ) \\
\hline \multirow[t]{4}{*}{ Nitrite, as $\mathrm{N}$} & Nitrogen, nitrite, dissolved ( $\mathrm{mg} / \mathrm{L}$ as $\mathrm{N})$ & 00613 \\
\hline & Nitrogen, nitrite, dissolved $\left(\mathrm{mg} / \mathrm{L}\right.$ as $\left.\mathrm{NO}_{2}\right)$ & 71856 (multiplied by 0.30446 ) \\
\hline & Nitrogen, nitrite, total (mg/L as $\mathrm{N}$ ) & 00615 \\
\hline & Nitrogen, nitrite, total $\left(\mathrm{mg} / \mathrm{L}\right.$ as $\left.\mathrm{NO}_{2}\right)$ & 71855 (multiplied by 0.30446 ) \\
\hline \multirow[t]{6}{*}{ Nitrate, as $\mathrm{N}$} & $\begin{array}{l}\text { Nitrogen, nitrite plus nitrate, dissolved (mg/L as } \mathrm{N} \text { ) } \\
\text { minus }{ }^{2} \text { nitrite, as } \mathrm{N}\end{array}$ & $\begin{array}{l}00631 \\
*\end{array}$ \\
\hline & $\begin{array}{l}\text { Nitrogen, nitrite plus nitrate, total (mg/L as } \mathrm{N} \text { ) } \\
\text { minus }{ }^{2} \text { nitrite, as } \mathrm{N}\end{array}$ & $\begin{array}{l}00630 \\
*\end{array}$ \\
\hline & Nitrogen, nitrate, dissolved (mg/L as $\mathrm{N})$ & 00618 \\
\hline & Nitrogen, nitrate, dissolved $\left(\mathrm{mg} / \mathrm{L}\right.$ as $\left.\mathrm{NO}_{3}\right)$ & 71851 (multiplied by 0.2259 ) \\
\hline & Nitrogen, nitrate, total (mg/L as $\mathrm{N})$ & 00620 \\
\hline & Nitrogen, nitrate, total $\left(\mathrm{mg} / \mathrm{L}\right.$ as $\left.\mathrm{NO}_{3}\right)$ & 71850 (multiplied by 0.2259 ) \\
\hline \multirow[t]{3}{*}{ Total nitrogen } & Nitrogen, total (mg/L as $\mathrm{N})$ & 00600 \\
\hline & Nitrogen, total (mg/L as $\mathrm{NO}_{3}$ ) & 71887 (multiplied by 0.2259 ) \\
\hline & $\begin{array}{l}{ }^{3} \text { Nitrogen, ammonia plus organic, total }(\mathrm{mg} / \mathrm{L} \text { as } \mathrm{N}) \\
\text { plus }{ }^{2} \text { nitrate, as } \mathrm{N} \text {, plus }{ }^{2} \text { nitrite, as } \mathrm{N}\end{array}$ & $\begin{array}{l}00625 \\
* * \\
*\end{array}$ \\
\hline \multirow[t]{4}{*}{ Orthophosphate, as P } & Phosphorus, orthophosphate, dissolved (mg/L as P) & 00671 \\
\hline & Phosphate, ortho, dissolved ( $\mathrm{mg} / \mathrm{L}$ as $\left.\mathrm{PO}_{4}\right)$ & 00660 (multiplied by 0.3261 ) \\
\hline & Phosphorus, orthophosphate, total (mg/L as P) & 70507 \\
\hline & Phosphate, total $\left(\mathrm{mg} / \mathrm{L}\right.$ as $\left.\mathrm{PO}_{4}\right)$ & 00650 (multiplied by 0.3261 ) \\
\hline \multirow[t]{2}{*}{ Total phosphorus } & Phosphorus, total (mg/L as P) & 00665 \\
\hline & Phosphorus, total (mg/L as $\left.\mathrm{PO}_{4}\right)$ & 71886 (multiplied by 0.3261 ) \\
\hline
\end{tabular}




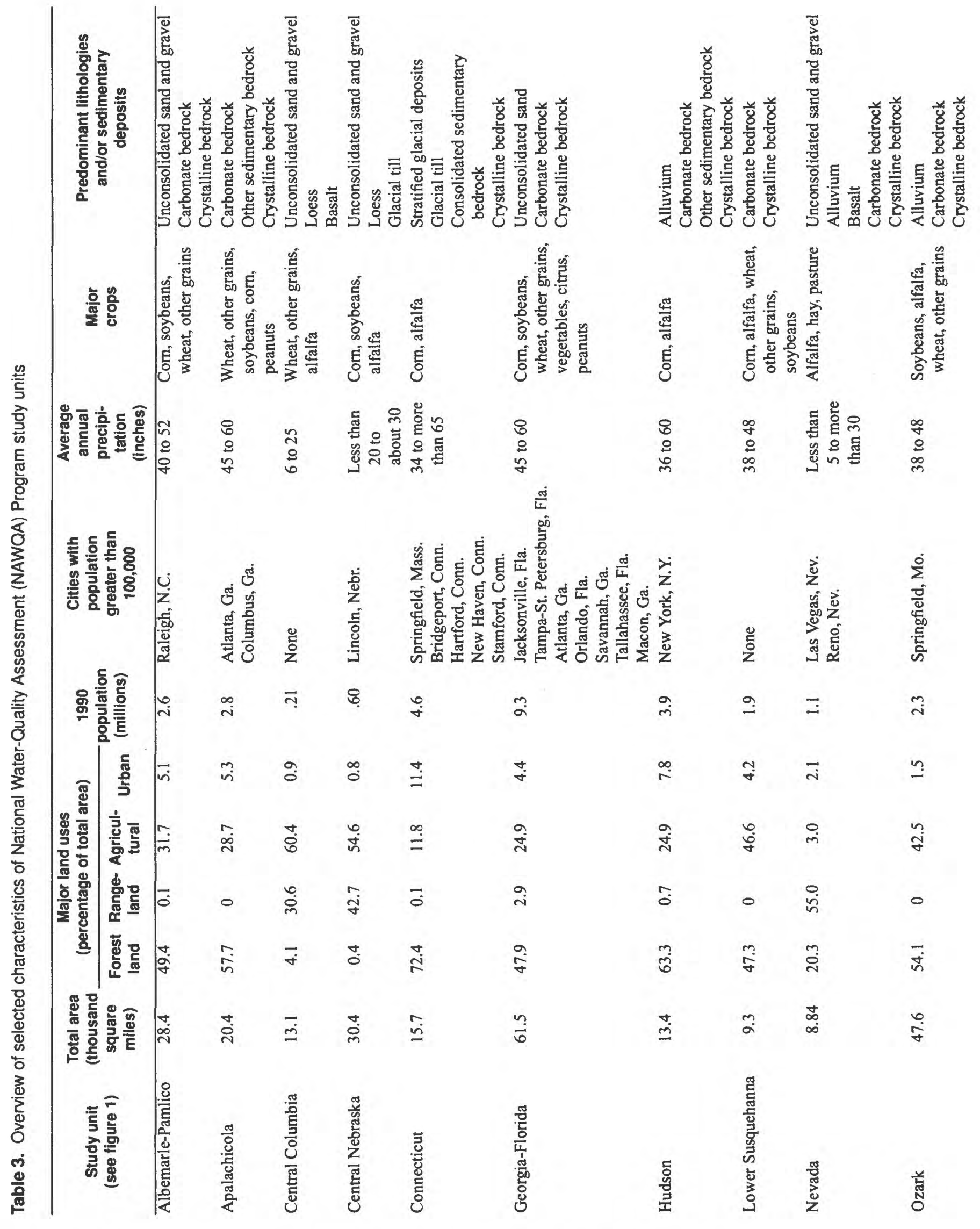




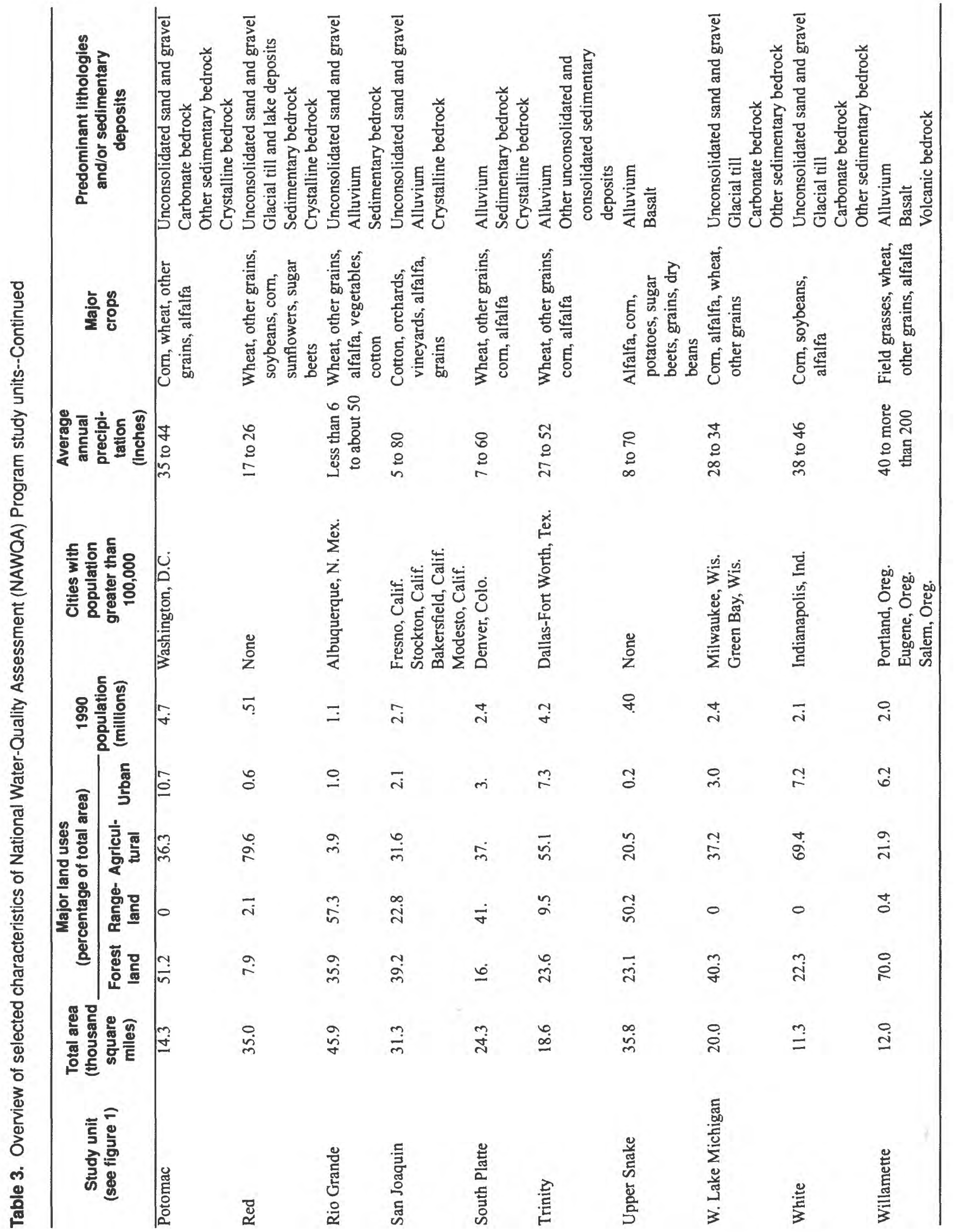


Classification of land use at ground-water sampling sites and upstream from surface-water sampling sites was based on categories described by Anderson and others (1976): Forest Land, Rangeland, Agricultural Land, Urban or Built-up (hereinafter referred to as Urban) Land, and Wetland. For groundwater sites, land-use settings were determined for individual well locations from USGS land-use and landcover digital (GIRAS) data (Fegeas and others, 1983). Land use and land cover could not be determined from the digital data for wells sampled in the Midcontinent Toxics study area; therefore, land use at these sites was classified as Agricultural if most of the land in the vicinity of the well was used for row crops, based on information provided by study personnel.

Most of the GIRAS data were collected during 1970-80. Since that time, some areas of the Nation have experienced land-use changes, such as forest or rangelands converted to agricultural use or agricultural lands converted to urban areas. However, because of the time required for water movement from the land surface to the underlying aquifer, land use during previous years is relevant to current ground-water-quality assessments. For surface-water drainage basins, where the traveltime from source areas to sampling sites is not as long, the GIRAS data were considered potentially obsolete and, therefore, inadequate for relating land use to nutrient concentrations in runoff. Classifications of surfacewater sites were made by the study-unit personnel, considering the dominant land use affecting each of the selected sites in their area.

Information on land use in agricultural areas was supplemented by county-level assessments of the extent of cropland, pasture, and woodlands (U.S. Bureau of the Census, 1989). Inorganic nitrogen fertilizer use was approximated by county-level fertilizer sales data (U.S. Environmental Protection Agency, 1990a). County-level estimates of animal-waste production were used to assess the nitrogen available from manure applications on cropland (R.B. Alexander, U.S. Geological Survey, written commun., 1992). These data were used in ground-water analyses by associating sampling wells with data for the county in which the well was located.

The population of drainage basins upstream from surface-water sampling sites was determined from census block groups located within the basin (U.S. Bureau of the Census, 1990). For block groups located only partially in the basin, population was apportioned to the basin as a percentage of the area of the block group within the basin.

Aquifer composition and brief descriptions of lithology were provided for each well location where information was available. Ground-water sampling sites were categorized into the following broad hydrogeologic settings, based on predominant lithology or sedimentary deposits:

- Unconsolidated sand and gravel.

- Alluvium.

- Glacial till.

- Basalt.

- Carbonate bedrock.

- Other bedrock (including cemented sandstones, shale, siliciclastics, and crystalline bedrock).

Soils information for well locations and for drainage basins upstream from surface-water sampling sites was obtained from digital maps produced by the U.S. Soil Conservation Service (1993). Soil hydrologic group is a categorical variable that integrates several factors, including runoff potential, permeability, depth to water table, depth to an impervious layer, water capacity, and shrink-swell potential (U.S. Soil Conservation Service, 1994). Soil hydrologic group classes are designated as follows:

- Hydrologic group A: These soils are well drained, having high rates of infiltration and water transmission and, consequently, low runoff potential.

- Hydrologic group B: These soils have moderate rates of infiltration and water transmission.

- Hydrologic group C: These soils have slow rates of infiltration and water transmission.

- Hydrologic group D: These soils are poorly drained, having very slow rates of infiltration and water transmission and, consequently, high runoff potential.

Soil hydrologic group classifications were aggregated from soil associations into mapping units defined in the digital maps. Numerical values were assigned to each group $(A=1, B=2, C=3, D=4)$, and the areaweighted mean for each mapping unit was calculated. This procedure produced a continuous variable, from 1 to 4, for each mapping unit. Ground-water sampling sites were assigned the hydrologic group number of the mapping unit in which the well was located. Hydrologic group numbers for drainage basins upstream from surface-water sampling sites were computed as the area-weighted mean of soil hydrologic groups for all mapping units within the basin. 


\section{Selection of Ground-Water Data for National Analyses}

The national assessment of nutrients in ground water was based on analyses of approximately 12,000 water samples collected from wells (and a few springs) in 18 of the 20 NAWQA study units and 5 supplemental study areas (table 4). These water-quality data were collected to meet diverse objectives ranging from monitoring for compliance with drinking-water standards and criteria to conducting research on specific ground-water issues. Two study units could not contribute data. In the Hudson study unit, few ground-water samples were collected during 1980-90. The available data were poorly distributed over space and time and had few records of depth or aquifer type. Data from the Red study unit had none of the ancillary information required for the national analysis; however, some results of the studyunit analysis (Tornes and Brigham, 1994) were included in this report.

Ground-water samples were selected for the national retrospective data set using the following criteria:

- Samples from wells around known or suspected areas of contamination were eliminated.-Data from wells used to monitor pollution from known or suspected sources within small areas can bias the results of a regional or national water-quality assessment. Samples from such monitoring wells that could be identified by study-unit personnel were eliminated.

- Samples from wells clustered in a small local area were eliminated.-Clustering of sampling sites can introduce a geographical bias to a regional or national assessment. To decrease the possibility of this bias, samples from clustered wells, as identified by study-unit personnel, were eliminated from the national data set. Because of the magnitude of the national data set, no other sampleelimination criteria, such as minimum distance between wells, were considered.

- In general, only the most recent sample from each well was retained. - Only one analysis from each well was included in the national data set to avoid bias toward wells from which many samples had been collected. For most wells, the analysis of the most recent sample was selected; however, some exceptions were necessary. The Central Nebraska study unit provided only one analysis for each well, from a single sample collected during or closest to 1986. Median concentrations were provided by five other study units, and these were retained in the national data set to maintain consistency with the individual study-unit results. The effect of combining these various types of data on interpretive results was assessed by replicating statistical tests and substituting data from the most recent sample in place of the median value for wells where both were available. Differences in the results of these tests were not significant.

- Concentrations measured in the field were eliminated.-Occasionally, chemical analyses for nutrient concentrations, particularly nitrate, are made at the sampling site; however, these might not be as accurate or precise as determinations made in the laboratory (Robertson, 1979). Field measurements of nitrate that were identified by study-unit personnel were eliminated.

The resulting national retrospective data set for nutrients in ground water is summarized in table 5. Data for nitrate concentrations were more abundant than for other nutrient constituents. Concentrations of the other nutrient constituents were low in ground water and were considered relatively unimportant compared to nitrate. Therefore, nitrate was the only nutrient considered in the analysis of the ground-water data set in the following section of this report.

Certain characteristics of historical data can limit their usefulness for national assessments (Hamilton and others, 1993b). Data-base structure and format, as well as differences among agencies in procedures for collecting and analyzing samples, might preclude the combination of data from different sources to form a meaningful assessment. Limitations of the national data set assembled for this analysis include:

- Inconsistent or lack of information on quality control and sampling objectives.

- Inconsistent sampling, preservation, and analytical techniques over time and among agencies.

- Lack of information on sampling location, water use, well depth, well construction, or aquifer characteristics.

Limitations of these types are inherent in an aggregated data set. For example, if quality-assurance guidelines and protocols are not followed consistently through the period of record, the variability in constituent concentrations due to differences in field or laboratory handling cannot be estimated. Sample-preservation and laboratory-analysis procedures can differ among agencies and might change during the period of record even within an agency. Reporting limits have decreased as laboratory technology has improved. Ancillary data are not always available (table 4) or are of questionable accuracy; some well-depth data are based only on the homeowner's knowledge or the driller's memory. Information on well construction and aquifer characteristics commonly are lacking. 


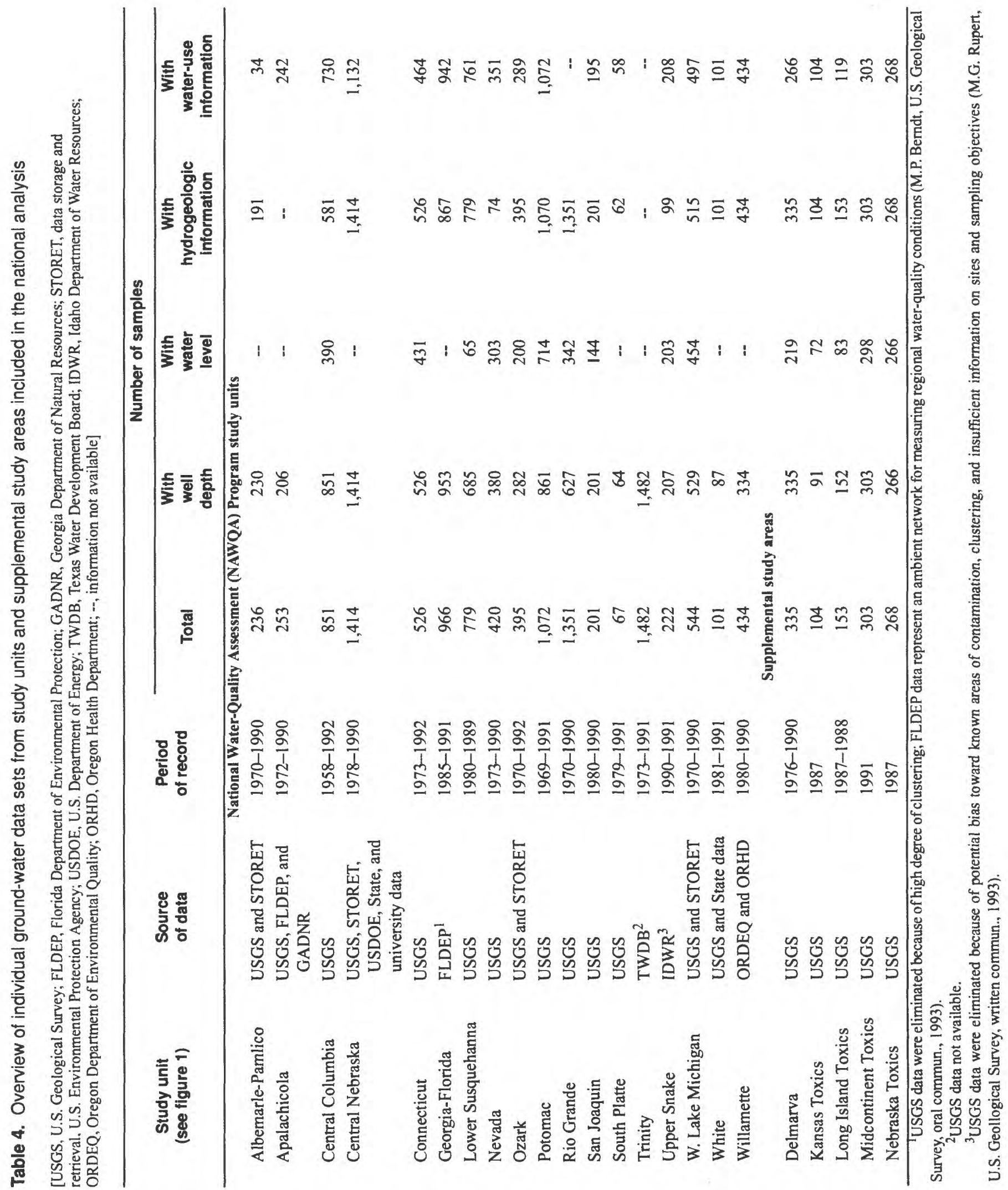


Table 5. Overview of selected nutrients in the national retrospective data set for ground water

[mg/L. milligram per liter]

\begin{tabular}{lcccc}
\hline $\begin{array}{c}\text { Sampled } \\
\text { nutrient } \\
\text { species }\end{array}$ & $\begin{array}{c}\text { Number } \\
\text { of wells } \\
\text { sampled } \\
\text { (one } \\
\text { sample } \\
\text { per site) }\end{array}$ & $\begin{array}{c}\text { Median } \\
\text { concen- } \\
\text { tratlon } \\
\text { (mg/L) }\end{array}$ & $\begin{array}{c}\text { Number } \\
\text { of study } \\
\text { units or } \\
\text { study areas } \\
\text { repre- } \\
\text { sented }\end{array}$ & $\begin{array}{c}\text { Number } \\
\text { of States } \\
\text { repre- } \\
\text { sented }\end{array}$ \\
\hline Ammonia & 3,515 & 0.02 & 19 & 34 \\
Nitrite & 2,700 & .01 & 13 & 28 \\
Nitrate & 11,715 & .58 & 23 & 38 \\
Total nitrogen & 122 & 1.05 & 7 & 12 \\
Orthophosphate & 3,641 & .02 & 19 & 36 \\
Total phosphorus & 1,318 & .05 & 13 & 24 \\
\hline
\end{tabular}

\section{Selection of Surface-Water Data for National Analyses}

Data used in the national analysis of nutrients in surface water were obtained from the data sets compiled for each of the 20 NAWQA study units. The time period was restricted to water years $1980-90$ because those years were common to the data sets from all study units. Samples were limited to one per month to avoid biasing the data toward more frequently sampled sites. If more than one sample was collected during any single month, only the sample collected nearest in time to the middle of the month was retained. Sites from the study-unit data sets were included in the national analysis only if they had a minimum of 25 samples with nutrient analyses. Sites that had an upstream drainage area of less than 5 square miles and samples collected from streamflows of less than $1 \mathrm{ft}^{3} / \mathrm{s}$ were excluded to avoid samples that were primarily effluent from individual sources.

For the purpose of the national retrospective analysis, study-unit personnel were asked to determine the dominant land use affecting each of the selected sites in their area. Land-use classifications were based on the Anderson Level I categories (Anderson and others, 1976). Many sites were classified as being affected by a combination of land uses, such as Forest/Wetland, Rangeland/Agricultural, or Agricultural/Urban. Sites were aggregated into the following summary land-use settings:

- Undeveloped: Forest Land, Forest/Wetland, Rangeland, and Forest/Rangeland.

- Agricultural/Undeveloped: Combinations of Agricultural Land with Forest Land, Rangeland, or Wetland.
- Agricultural: Agricultural Land and Agricultural/ Undeveloped sites where more than 50 percent of the upstream area was Agricultural Land.

- Agricultural/Urban: Combinations of Agricultural and Urban Lands.

- Urban/Undeveloped: Combinations of Urban Land with Forest Land or Rangeland.

- Urban: Urban Land and Urban/Undeveloped sites where more than 20 percent of the upstream area was Urban Land.

Note that "Undeveloped" sites may not be completely unaffected by anthropogenic development, but agricultural and urban areas do not have a dominant impact.

Sites with very large (greater than 10,000 square miles) drainage areas are probably affected by an integration of many upstream factors, including a variety of land uses. These sites were categorized as LargeIntegrator sites and were analyzed separately. A few sites with other dominant land uses, such as mining, and sites that were directly downstream from large reservoirs were not included. The resultant national retrospective data set included more than 22,000 samples from more than 300 sites. The distribution of samples and sites is summarized by study unit in table 6 and by land-use setting in table 7.

Several characteristics of the national retrospective data set, some of which are apparent in tables 6 and 7, limit the usefulness of the data for interpretation. The samples and sampling sites were not uniformly distributed among the study units, even considering differences in study-unit area. The distribution among landuse settings also was not uniform. Agriculture was considered at least partially dominant upstream from more than one-half the total sites. Urban land use was at least partially dominant upstream from less than 25 percent of the sites, and at about one-third of these sites, agriculture also was partially dominant. Only about 10 percent of the sites had large drainage basins where many landuse effects are integrated.

Also according to the data in tables 6 and 7, the number of chemical analyses differed by constituent. Nitrate and total phosphorus were analyzed in more than 85 percent of all samples, but orthophosphate was analyzed only in about 38 percent of the samples. In many cases, different constituents were measured at different sites or during different time periods. Thus, some sites might have data only for nitrate and total phosphorus, and other sites might have data only for ammonia and orthophosphate. Conversely, analyses of samples from a particular site might include both nitrate and ammonia during part of the period of record but only nitrate during the remainder of the time. These characteristics of the data set make meaningful comparisons between nutrient species difficult. 
Table 6. Distribution of surface-water samples by National Water-Quality Assessment (NAWQA) Program study unit

\begin{tabular}{|c|c|c|c|c|c|c|c|}
\hline \multirow{2}{*}{$\begin{array}{l}\text { Study unit } \\
\text { (see figure 1) }\end{array}$} & \multirow{2}{*}{$\begin{array}{l}\text { Number } \\
\text { of sites }\end{array}$} & \multicolumn{6}{|c|}{ Number of samples } \\
\hline & & Total & Ammonia & Nitrate & $\begin{array}{c}\text { Total } \\
\text { nitrogen }\end{array}$ & $\begin{array}{c}\text { Ortho- } \\
\text { phosphate }\end{array}$ & $\begin{array}{c}\text { Total } \\
\text { phosphorus }\end{array}$ \\
\hline Albemarle-Pamlico & 16 & 1,064 & 634 & 948 & 712 & 637 & 713 \\
\hline Apalachicola & 19 & 1,977 & 1,908 & 1,947 & 656 & 218 & 1,969 \\
\hline Central Columbia & 15 & 931 & 485 & 919 & 532 & 834 & 905 \\
\hline Central Nebraska & 10 & 861 & 808 & 859 & 696 & 175 & 810 \\
\hline Connecticut & 16 & 1,832 & 1,814 & 1,816 & 1,809 & 339 & 1,814 \\
\hline Georgia-Florida & 32 & 2,286 & 2,183 & 2,236 & 865 & 242 & 2,201 \\
\hline Hudson & 3 & 161 & 101 & 154 & 136 & 84 & 149 \\
\hline Lower Susquehanna & 15 & 1,045 & 999 & 1,002 & 962 & 863 & 1,016 \\
\hline Nevada & 16 & 1,200 & 1,001 & 411 & 289 & 1,000 & 322 \\
\hline Ozark & 32 & 2,265 & 2,118 & 2,134 & 679 & 490 & 2,135 \\
\hline Potomac & 15 & 1,194 & 301 & 1,187 & 1,040 & 899 & 1,062 \\
\hline Red & 10 & 744 & 674 & 711 & 410 & 273 & 713 \\
\hline Rio Grande & 21 & 1,135 & 243 & 538 & 348 & 539 & 828 \\
\hline San Joaquin & 15 & 803 & 646 & 741 & 635 & 618 & 716 \\
\hline South Platte & 14 & 964 & 489 & 722 & 508 & 170 & 176 \\
\hline Trinity & 12 & 550 & 510 & 492 & 546 & 0 & 546 \\
\hline Upper Snake & 14 & 766 & 193 & 677 & 528 & 275 & 765 \\
\hline W. Lake Michigan & 15 & 1,006 & 676 & 730 & 668 & 570 & 939 \\
\hline White & 11 & 1,064 & 1,063 & 1,060 & 669 & 0 & 1,063 \\
\hline Willamette & 5 & 521 & 408 & 441 & 348 & 379 & 380 \\
\hline Total & 306 & 22,369 & 17,254 & 19,725 & 13,036 & 8,605 & 19,211 \\
\hline
\end{tabular}

Table 7. Distribution of surface-water samples by dominant upstream land use

\begin{tabular}{|c|c|c|c|c|c|c|c|}
\hline \multirow{2}{*}{$\begin{array}{l}\text { Land-use } \\
\text { setting }\end{array}$} & \multirow{2}{*}{$\begin{array}{l}\text { Number } \\
\text { of sites }\end{array}$} & \multicolumn{6}{|c|}{ Number of samples } \\
\hline & & Total & Ammonia & Nitrate & $\begin{array}{c}\text { Total } \\
\text { nitrogen }\end{array}$ & $\begin{array}{c}\text { Ortho- } \\
\text { phosphate }\end{array}$ & $\begin{array}{c}\text { Total } \\
\text { phosphorus }\end{array}$ \\
\hline Undeveloped & 67 & 4,593 & 3,099 & 3,751 & 2,584 & 1,993 & 3,782 \\
\hline $\begin{array}{l}\text { Agricultural/ } \\
\text { Undeveloped }\end{array}$ & 48 & 3,052 & 2,555 & 2,965 & 1,505 & 1,218 & 2,788 \\
\hline Agricultural & 86 & 6,028 & 4,494 & 5,392 & 3,628 & 2,798 & 5,507 \\
\hline $\begin{array}{l}\text { Agricultural/ } \\
\text { Urban }\end{array}$ & 27 & 2,217 & 1,802 & 2,140 & 1,330 & 634 & 1,962 \\
\hline $\begin{array}{l}\text { Urban/ } \\
\text { Undeveloped }\end{array}$ & 13 & 1,239 & 1,060 & 1,153 & 490 & 161 & 1,026 \\
\hline Urban & 34 & 2,812 & 2,479 & 2,264 & 1,661 & 725 & 2,109 \\
\hline $\begin{array}{l}\text { Large } \\
\text { Integrator }\end{array}$ & 31 & 2,428 & 1,765 & 2,060 & 1,838 & 1,076 & 2,037 \\
\hline
\end{tabular}


Another factor that complicates the interpretation of the national retrospective data set is differences in the periods of record among sites. Few sites had a complete monthly record for even one constituent during the selected period (water years 1980-90). For many sites, sampling was concentrated at either the beginning or the end of the period. Thus, the spatial distribution of samples varies with time in the data set. In addition, the distribution of sites is not necessarily representative of the primary land uses in a study unit. For example, the Potomac study unit includes Washington, D.C., but few sampling sites with existing data were downstream from urban land uses. The dominant land use upstream from most sites in this study unit was agricultural. This distribution probably reflects the local water-quality concerns during the selected time period. Local concerns, rather than nationally consistent and representative sampling, were probably primary in most of the programs that were the source of the existing data.

\section{Data-Analysis Procedures}

The methods used to analyze nutrient data were graphical and statistical. Data distributions were displayed graphically by using truncated boxplots (Helsel and Hirsch, 1992, p. 26). These plots show five percentiles of the data distribution: 10th, 25th, 50th (median), 75 th, and 90th (fig. 2). Individually, boxplots can indicate properties of the distribution, such as spread and skewness. Side-by-side boxplots can be used to visually compare two or more data distributions. Letters were placed next to the median of each plot to show the results of a multiple comparison test. Plots identified by the same letter indicate that the medians were not significantly different. If two letters are listed (for example, BC), the median was not significantly different from other medians identified by either one of those letters (for example, $\mathrm{B}, \mathrm{C}, \mathrm{AB}, \mathrm{BC}$, or $\mathrm{CD}$ ).

Because many of the plotted distributions did not appear to be normal and because differences in standard deviation were obvious from variations in spread, nonparametric statistical methods were chosen to test for differences among groups of data. Nonparametric statistics involve robust techniques that generally are not sensitive to outlying values or to assumptions of equal variance and normality. The Kruskal-Wallis test (Iman and Conover, 1983, p. 418-420) was used to test for differences in median values. This test was calculated by performing a one-way analysis of variance on the ranks of the data (Conover and Iman, 1981). An alpha value of 0.05 was used to evaluate the significance of test results. If a significant difference among data-group medians was indicated, individual differences between medians were evaluated by applying Tukey's multiple comparison test (Helsel and Hirsch, 1992, p. 196) to the rank-transformed data.

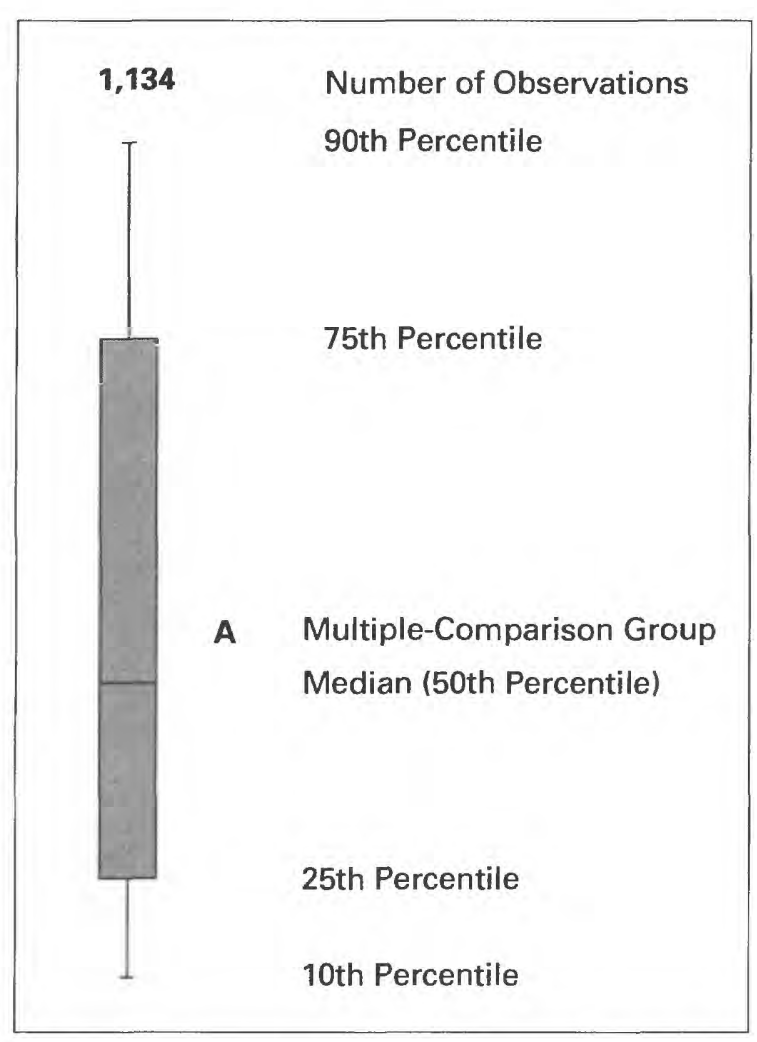

Figure 2. Example diagram and explanation of a boxplot.

Relations between nutrient concentrations and selected ancillary data were investigated by using nonparametric correlation analysis (Helsel and Hirsch, 1992, p. 210-218). This technique identifies monotonic, although not necessarily linear, correlation. Results of this test are reported as Spearman's correlation coefficient (rho). In this analysis, a significant result indicates that the correlation coefficient is different from 0 . The strength of the monotonic relation is determined by the magnitude of the coefficient. All statistical computations used in the data analysis were made by using commercially available statisticssoftware procedures (SAS Institute, 1990). 
In some instances, the dependence of nutrient concentrations on an ancillary variable was displayed by plotting a smooth line through the center of the data. The LOWESS method (Helsel and Hirsch, 1992, p. 286-291) was used to compute the coordinates of the smooth lines. This method depicts the general shape of the relation between two variables, regardless of whether that relation is linear or nonlinear. Upper and lower smooth lines also can be plotted to indicate the variation about the central relation.

The approaches to data interpretation in the two major sections of this report, describing nutrients in ground water and in surface water, are not the same. More types of ancillary data were available for groundwater sampling sites than for surface-water sites. The ground-water data interpretation is organized to present differences in nutrient concentrations related to a variety of ancillary factors. Analysis of the national retrospective data set is reported, and probable relations of the ancillary factors to the nutrient concentrations are discussed. Results from individual study-unit investigations are summarized to provide local examples of national results. In the surface-water section, the relation between nutrient concentrations and upstream land use is emphasized. Results of the study-unit investigations are used to point out various land-use factors that might affect downstream surface-water quality. The analysis of the national retrospective data set, then, focuses on differences in water quality at sites downstream from different land uses.

\section{NUTRIENTS IN GROUND WATER OF THE UNITED STATES}

The nutrient of primary interest in most studies of ground water has been nitrate. This emphasis arises from the prevalence of nitrate contamination in ground water and from the regulation of nitrate in drinkingwater supplies. Elevated concentrations of other nutrients in ground water are less common than nitrate. Also, these other nutrients are regulated primarily for their effect on aquatic life, which is not of concern in ground water. National analyses and reviews of existing information have proven valuable in describing the occurrence and distribution of nitrate in the ground water of the United States and in identifying broad regions where nitrate-related problems exist. For example, Hallberg (1989) has reported that the major areas that have problems with nitrate contamination of ground water include parts of the Northeastern, Midwestern, and West Coast States, but Spalding and Exner (1993) have reported that ground water beneath agricultural areas in large parts of the Southeastern and North-Central States was not contaminated. Even though the ground-water-quality data analyzed in these studies were collected by a diverse group of organizations for a wide range of purposes, and even though their time periods differed and spatial coverage was limited, the national analyses were useful for constructing initial descriptions of ground-water quality, in developing hypotheses about major factors that affect the ground-water quality, and in defining additional data needs. Our analyses supplement the findings of these previous studies by providing a regional and national perspective on existing ground-water data collected in the NAWQA study units and Toxics Program study areas.

\section{Nitrate Concentrations in Ground Water Used for Drinking and Irrigation}

Analysis of the national retrospective data set indicated significant differences among nitrate concentrations in samples collected from different types of water-supply wells (fig. 3). Median nitrate concentrations in more than 5,600 samples ranged from $0.2 \mathrm{mg} / \mathrm{L}$ for public-supply wells to $2.4 \mathrm{mg} / \mathrm{L}$ for irrigation and stock wells (table 8). Concentrations of nitrate exceeded the drinking-water MCL most frequently in samples collected from irrigation and stock wells and in only about 1 percent of the samples collected from public-supply wells. This relatively low percentage is consistent with findings of the USEPA National Pesticide Survey, which reported that nitrate concentrations in only 1.2 percent of 566 samples from publicsupply wells exceeded the MCL (U.S. Environmental Protection Agency, 1990c). Concentrations exceeded the MCL in about 9 percent of the 3,351 water samples from domestic-supply wells in the national retrospective data set but only in 2.4 percent of 783 rural domesticsupply wells as reported by the National Pesticide Survey. Differences in these results are most likely related to land use. Sampling sites in the National Pesticide Survey were selected without regard to land use, and inclusion of samples from wells in nonagricultural areas might have decreased the percentage of concentrations that exceeded the MCL (Spalding and Exner, 1993). More than one-half of the samples included in the national retrospective data set were collected from wells in agricultural areas. 


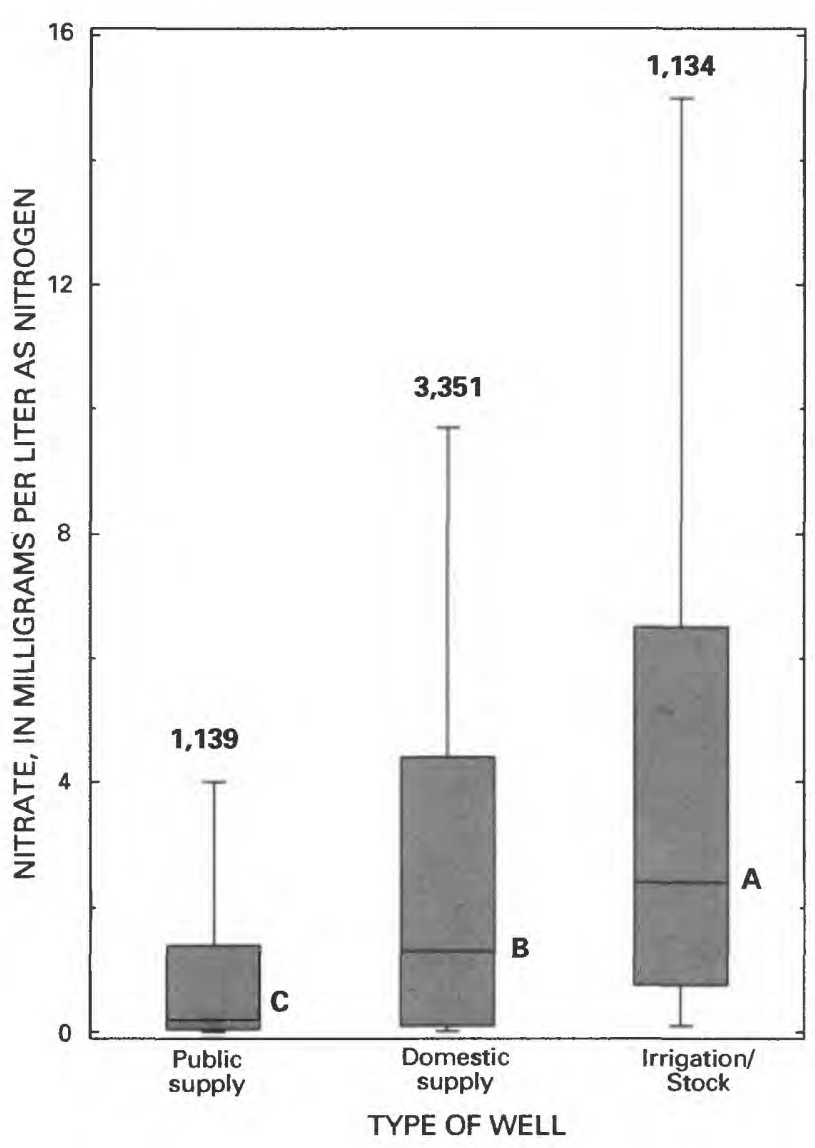

Figure 3. Nitrate concentrations in ground water by type of well use for samples in the national retrospective data set.

Table 8. Summary of nitrate concentrations in ground water by well type

[mg/L, milligram per liter]

\begin{tabular}{|c|c|c|c|}
\hline \multirow[b]{2}{*}{$\begin{array}{l}\text { Type } \\
\text { of well }\end{array}$} & \multirow[b]{2}{*}{$\begin{array}{l}\text { Number } \\
\text { of wells }\end{array}$} & \multicolumn{2}{|c|}{ Nitrate concentration } \\
\hline & & $\begin{array}{l}\text { Median } \\
\text { (mg/L) }\end{array}$ & $\begin{array}{c}\text { Exceeding } \\
\text { drinking-water } \\
\text { MCL }{ }^{2} \\
\text { (percent) }\end{array}$ \\
\hline Public water supply & 1,139 & 0.2 & 1.0 \\
\hline Domestic water supply & 3,351 & 1.3 & 9.0 \\
\hline Irrigation and stock water & 1,134 & 2.4 & 15.6 \\
\hline
\end{tabular}

The significantly higher nitrate concentrations in samples collected at stock wells might be caused by watering, feeding, or corralling animals near the well. In addition, many stock wells are old and poorly maintained, allowing nitrates from manure to percolate down the well to the water table. The significantly lower nitrate concentrations in samples collected from public-supply wells might be related to several factors:
- Public-supply wells commonly are completed in deeper parts of the ground-water system where contaminants are not as prevalent. Median depth of public-supply wells included in the national retrospective data set was 260 feet below land surface, nearly twice the median depth (138 feet) of domestic-supply wells.

- Public-supply wells generally have high-capacity pumps that draw ground water from a large vertical interval, increasing the potential for dilution of contaminants that generally occur in the upper levels of an aquifer.

- Public-supply wells from which nitrate concentrations exceed drinking-water MCL's generally are abandoned and, therefore, were not as likely to be included in the data set.

- Public-supply wells generally are located in areas where nitrate concentrations in the ground water are expected to be low, but domestic-supply wells might be located in close proximity to septic systems, agricultural fields, or animal feeding areas, all of which are potential sources of nitrate contamination.

Differences in sampling times and procedures, soil type, hydrologic conditions, and land use also can affect the comparison of nitrate concentrations in samples collected from the different types of wells.

Local-scale reports from several NAWQA study units also indicated that nitrate concentrations were significantly different in samples collected from wells used for different types of water supply. In the Apalachicola study unit, for example, nitrate concentrations were significantly higher in domestic-supply wells than in deeper public-supply wells (fig. 4; E.A. Frick, U.S. Geological Survey, written commun., 1994). Less nitrate is being consumed by people using public-supply rather than domestic-supply wells in that area. Results of the Willamette study (Bonn and others, in press) suggest that depth is one of the primary causes of differences in quality between well types. They found nitrate concentrations to be an order of magnitude higher in domestic-supply wells when compared to public-supply wells, until differences in depth were accounted for. Considering only data from the shallowest public-supply wells, with depths similar to the group of domestic-supply wells, differences in nitrate concentrations between the well types were not significant. 


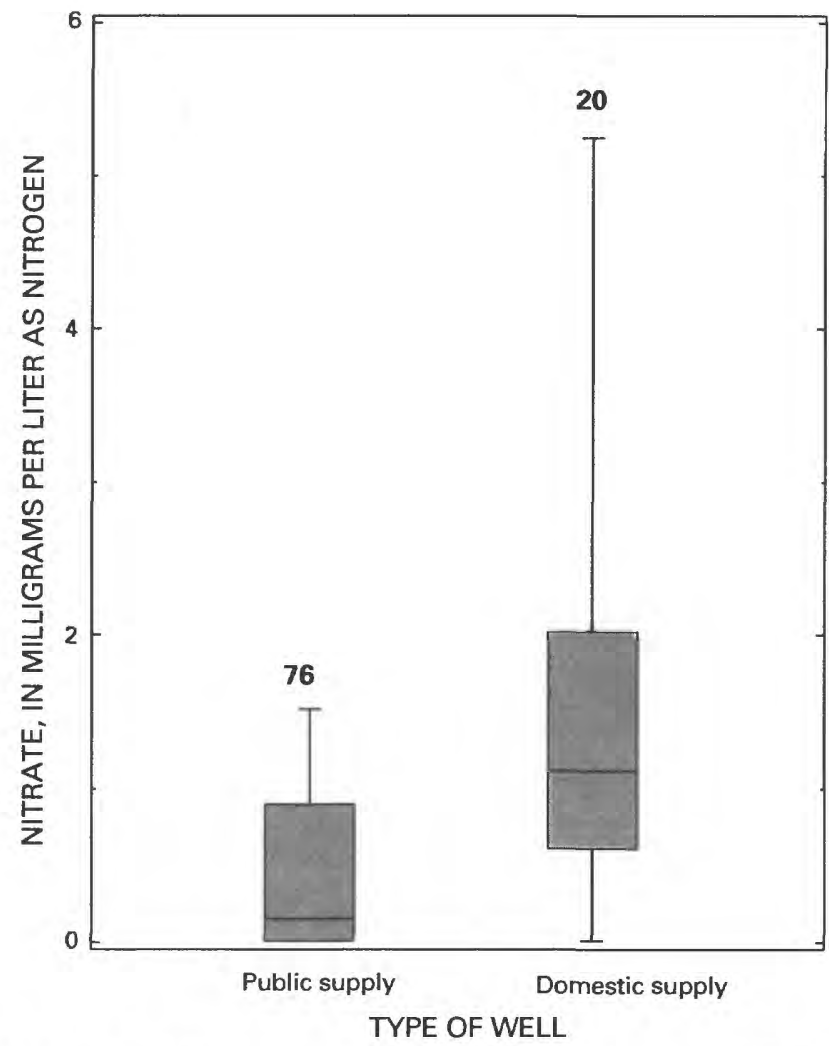

Figure 4. Nitrate concentrations in ground water by type of well use in the Apalachicola-Chattahoochee-Flint River Basin study unit (from E.A. Frick, U.S. Geological Survey, written commun., 1994).

\section{Factors Affecting Nitrate Concentrations in Ground Water}

Several factors that affect the concentrations of nitrate in wells are discussed below. In each section, one factor is analyzed in order to discern national patterns, which then are compared to results from individual study units. Much of the variability in each analysis is due to the simultaneous influence of the other factors.

\section{Land Use}

The data set for national analysis of groundwater quality beneath different land-use settings was limited to samples from wells completed no more than 100 feet below land surface. This criterion was chosen so that samples would be likely to reflect the effects of land use and related human activities at the surface. Nitrate concentrations were significantly different in ground water beneath different land-use settings (fig. 5). Concentrations were significantly higher beneath Agricultural Land than under any other landuse setting. Median concentrations ranged from
$0.1 \mathrm{mg} / \mathrm{L}$ in ground water beneath Forest Land to $3.4 \mathrm{mg} / \mathrm{L}$ in ground water beneath Agricultural Land (table 9). Concentrations in about 21 percent of the samples collected beneath Agricultural Land exceeded the drinking-water MCL.

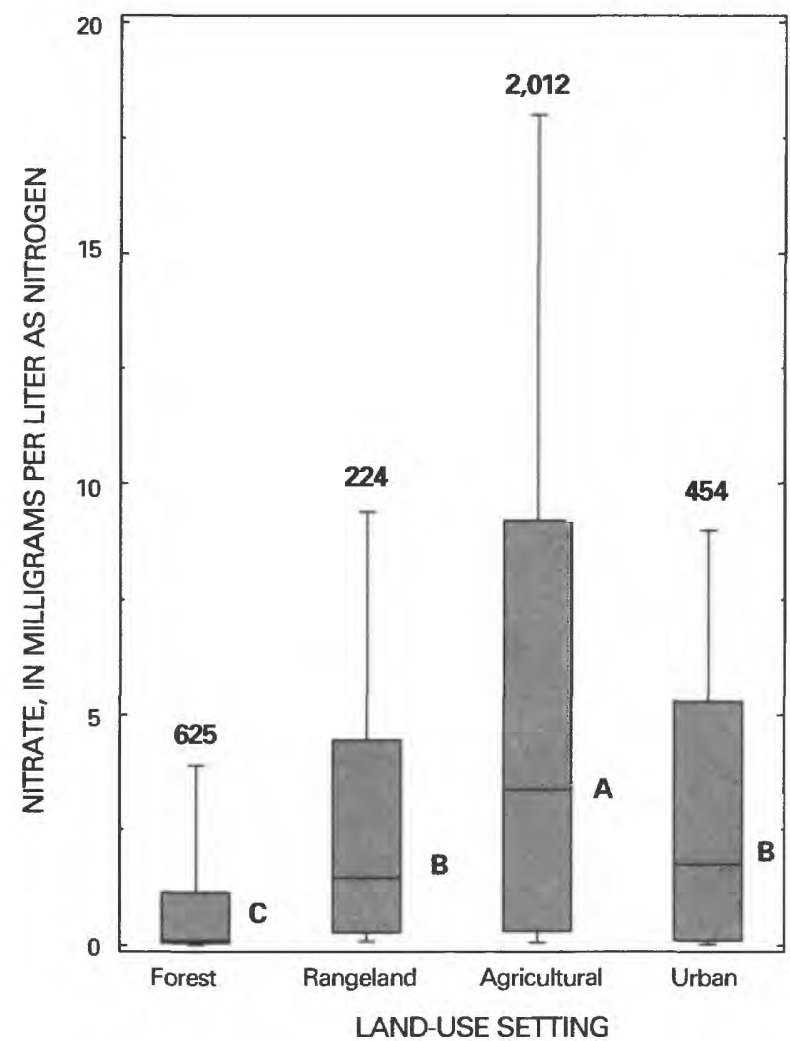

Figure 5. Nitrate concentrations in ground water beneath different land-use settings for samples in the national retrospective data set.

Table 9. Summary of nitrate concentrations in ground water beneath different land-use settings

[mg/L, milligram per liter]

\begin{tabular}{|c|c|c|c|}
\hline \multirow[b]{2}{*}{$\begin{array}{l}\text { Land-use } \\
\text { setting }^{1}\end{array}$} & \multirow[b]{2}{*}{$\begin{array}{l}\text { Number } \\
\text { of wells }{ }^{2}\end{array}$} & \multicolumn{2}{|c|}{ Nitrate concentration } \\
\hline & & $\begin{array}{l}\text { Median } \\
\text { (mg/L) }\end{array}$ & $\begin{array}{c}\text { Exceeding } \\
\text { drinking-water } \\
\text { MCL }^{3} \\
\text { (percent) }\end{array}$ \\
\hline Forest Land & 625 & 0.1 & 3.0 \\
\hline Rangeland & 224 & 1.5 & 8.5 \\
\hline Agricultural Land & 2,012 & 3.4 & 21.2 \\
\hline Urban Land & 454 & 1.8 & 7.0 \\
\hline 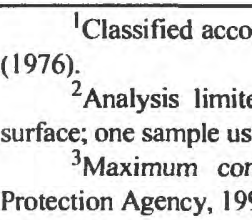 & $\begin{array}{l}\text { ding to categ } \\
\text { d to wells s } \\
\text { e per well. } \\
\text { taminant lev } \\
\text { Ob). }\end{array}$ & $\begin{array}{l}\text { es defined } \\
\text { pled withi } \\
(10 \mathrm{mg} / \mathrm{L}\end{array}$ & $\begin{array}{l}\text { Anderson and other } \\
00 \text { feet below lanc } \\
\text { U.S. Environmenta }\end{array}$ \\
\hline
\end{tabular}


Animal feedlots and fertilizers applied at the surface are likely sources of elevated nitrate concentrations in ground water beneath Agricultural Land. In urban areas, sources might be wastewater effluent and application of fertilizers on lawns, golf courses, and parks. Nitrate concentrations in ground water were lower in samples from Urban Land than in samples from Agricultural Land, probably because the sources of nitrogen in urban areas are relatively small and localized compared to the more intensive use of fertilizers on cropland. The potential for direct application of nitrogen fertilizer in ground-water recharge zones is greater in agricultural areas.

Concentrations of nitrate in ground water beneath Forest Land were significantly lower than concentrations in samples from any other land-use setting. Also, concentration ratios of ammonia to nitrate were significantly higher in ground water beneath Forest Land than in ground water beneath other landuse settings. The greater fraction of ammonia in ground water beneath Forest Land is often the result of poor drainage and anaerobic conditions, which inhibit nitrification of ammonia to nitrate. Poorly drained environments are more common in forests than in agricultural and urban areas, particularly in the Eastern United States.

In 15 of the 20 NAWQA study units, nitrate concentrations were higher in ground water beneath Agricultural Land than in ground water beneath Undeveloped Land (Forest or Rangeland) (fig. 6). For example, in the predominantly agricultural Central Nebraska study unit, concentrations exceeded the drinking-water MCL in 65 percent of the samples collected from shallow wells (maximum depth of 80 feet) in actively farmed areas of the Platte River Valley (Helgesen and others, 1994). Study units also found that nitrate concentrations differed in ground water among different types of Agricultural Land. For example, in the Upper Snake, Central Columbia, and Central Nebraska study units, nitrate concentrations were higher in ground water beneath irrigated cropland than beneath dryland farming areas, probably because of greater ground-water recharge in irrigated areas. Concentrations of nitrate also were elevated in samples from shallow wells (maximum depth of 100 feet) in urban areas, as well as agricultural areas, of the Potomac, Nevada, Willamette, and Connecticut study units. Figure 7 shows the effect of land use on shallow ground-water quality in the Connecticut study unit.

\section{Depth Below Land Surface}

Analysis of the national retrospective data set indicates that nitrate concentrations decrease with depth (fig. 8). In order to see this relationship clearly, the data shown in figure 8 are taken only from under Agricultural Land to remove the variability due to land use. The center line of figure 8 describes how the expected mean concentration decreases with depth, while the shaded area indicates the variability of the expected mean. The correlation between concentration and well depth was statistically significant $(\mathrm{rho}=0.31)$; although, as expected for data from across the Nation, there is a lot of scatter. Concentrations decrease quickly to depths of about 150 feet and then decrease more slowly. However, elevated nitrate concentrations, including a few that exceeded the MCL, were found in specific locations at depths greater than 500 feet below land surface (table 10). This can occur when the hydrogeologic setting allows deep percolation.

The decrease in nitrate concentration with depth is partly a function of the characteristics of the unsaturated zone overlying the aquifer and the depth to the water table. Fine-grained soils and a thick unsaturated zone can impede vertical movement of nitrate to deep parts of the ground-water system (Hallberg, 1989, p. 58). Because of the time involved for ground water to move vertically in some areas, the full impact of nitrogen-fertilizer applications might not be noted in some aquifers for 30 to 40 years (Hallberg and Keeney, 1993, p. 317). Agricultural areas where high nitrate concentrations occur in deeper wells generally are underlain by well-drained and permeable deposits, characterized by aerobic conditions. In these environments, nitrate quickly moves downward and is not chemically reduced along ground-water flow paths.

The decrease in nitrate concentration with depth is also, in part, a function of hydrogeologic conditions. Deep wells commonly penetrate bedrock aquifers, which often are confined, receive regional, indirect, and variable recharge, and have relatively long and deep flow paths. The water quality in these wells is, therefore, much less likely to reflect the overlying land use. In contrast, shallow wells in unconsolidated material receive relatively uniform and extensive recharge and are more susceptible to contamination by surface sources (Burkart and Kolpin, 1993). Denitrification also can increase with depth because of decreased dissolved oxygen (Spalding and Exner, 1993), as indicated by data from 11 study units in 24 States.

Concentrations of dissolved oxygen decreased significantly with well depth, based on data from 543 wells extending to a maximum depth of 1,990 feet below land surface. 


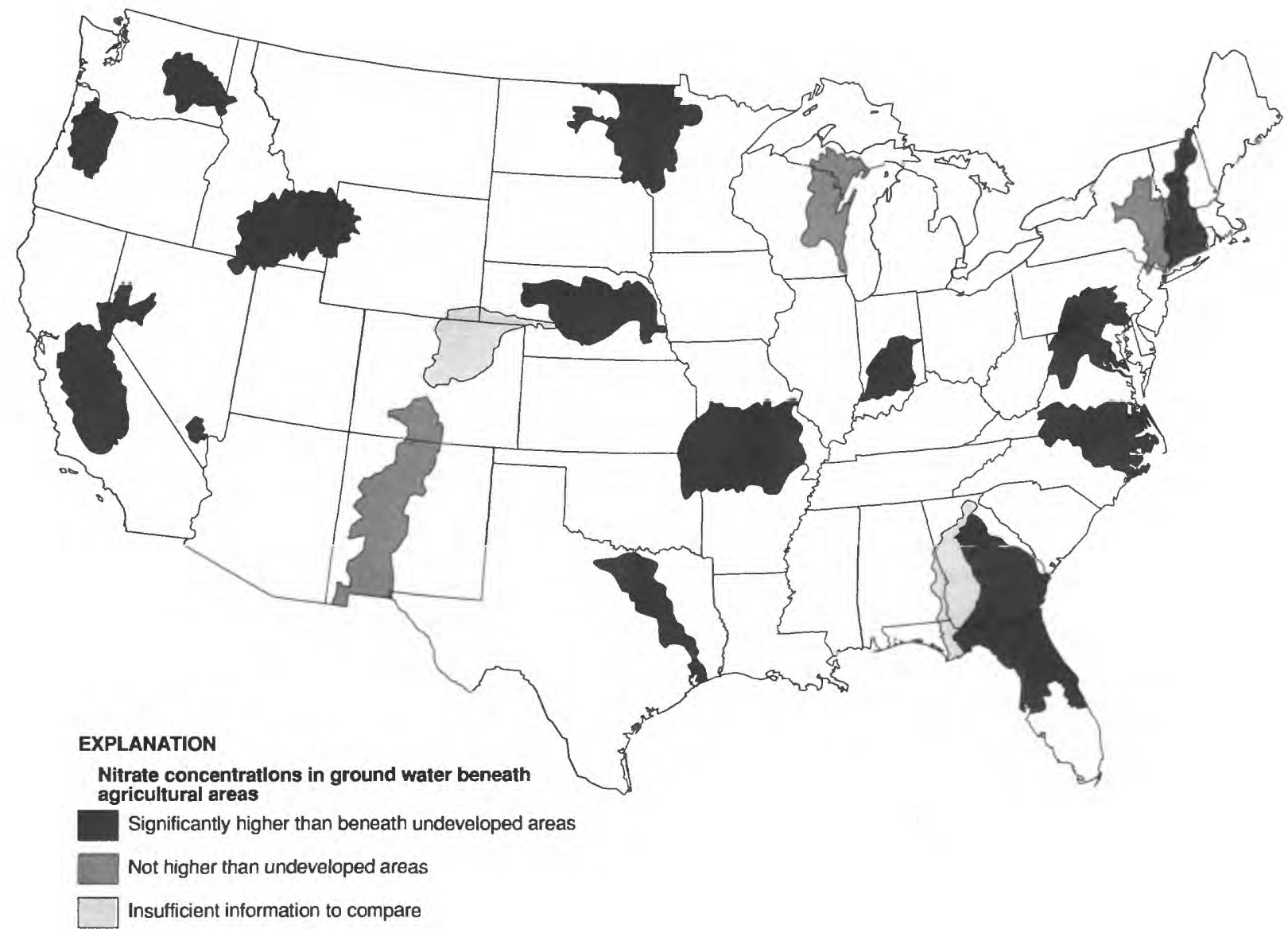

Figure 6. NAWQA study units where nitrate concentrations in ground water were significantly higher beneath agricultural areas than beneath undeveloped areas (refer to figure 1 for study-unit identification). 


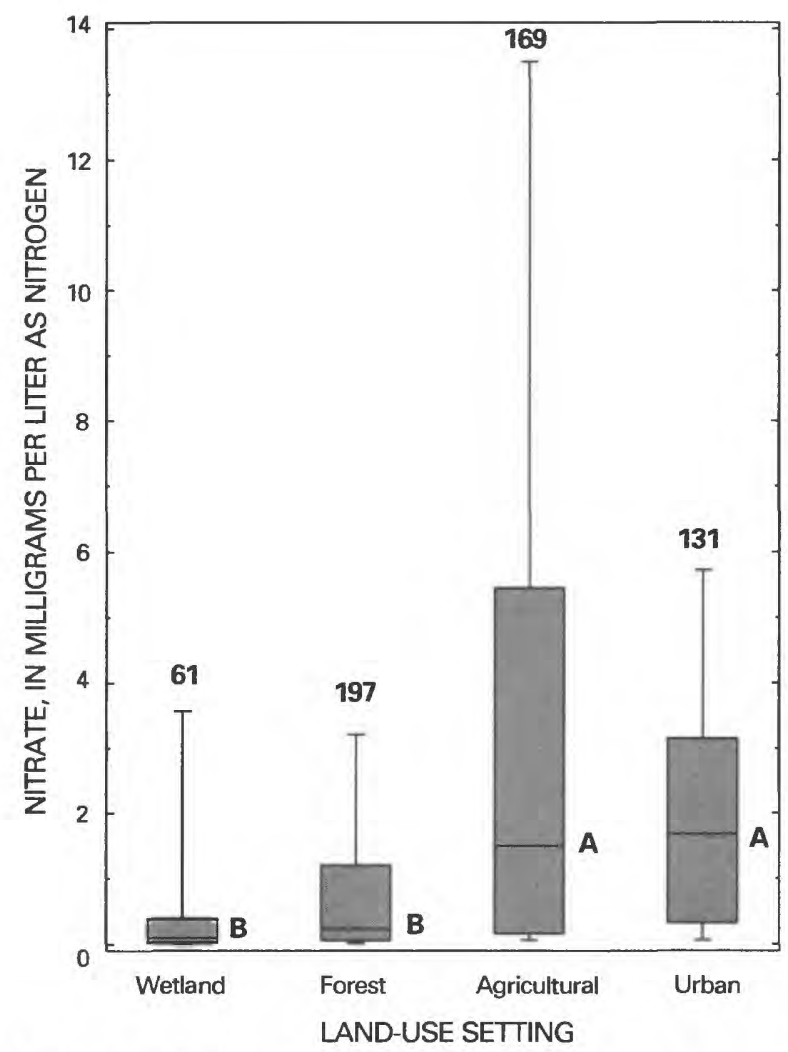

Figure 7. Nitrate concentrations in ground water beneath different land-use settings in the Connecticut, Housatonic, and Thames River Basins study unit (from M.J. Zimmerman, U.S. Geological Survey, written commun., 1994).

In 17 of the 20 NAWQA study units, nitrate concentrations were related to the depth of the well from which the sample came (fig. 9). The other three study units had insufficient data to examine this relationship. For example, figure 10 shows that nitrate concentrations in each of the geographic subdivisions of the Central Nebraska study unit were lower in samples from deeper wells. Figure 11 illustrates the decrease in nitrate concentrations under Agricultural Land in the Potomac study unit. In the Albemarle-Pamlico study unit, nitrate concentrations were consistently lower in wells deeper than 100 feet below land surface. In the Lower Susquehanna study unit, samples from wells as deep as $\mathbf{2 0 0}$ feet within similar land-use settings had similar nitrate concentrations, but below that depth, concentrations began to decrease. Similarly, shallow springs in the Ozark study unit had significantly higher nitrate concentrations than did deeper well waters from the same aquifer.

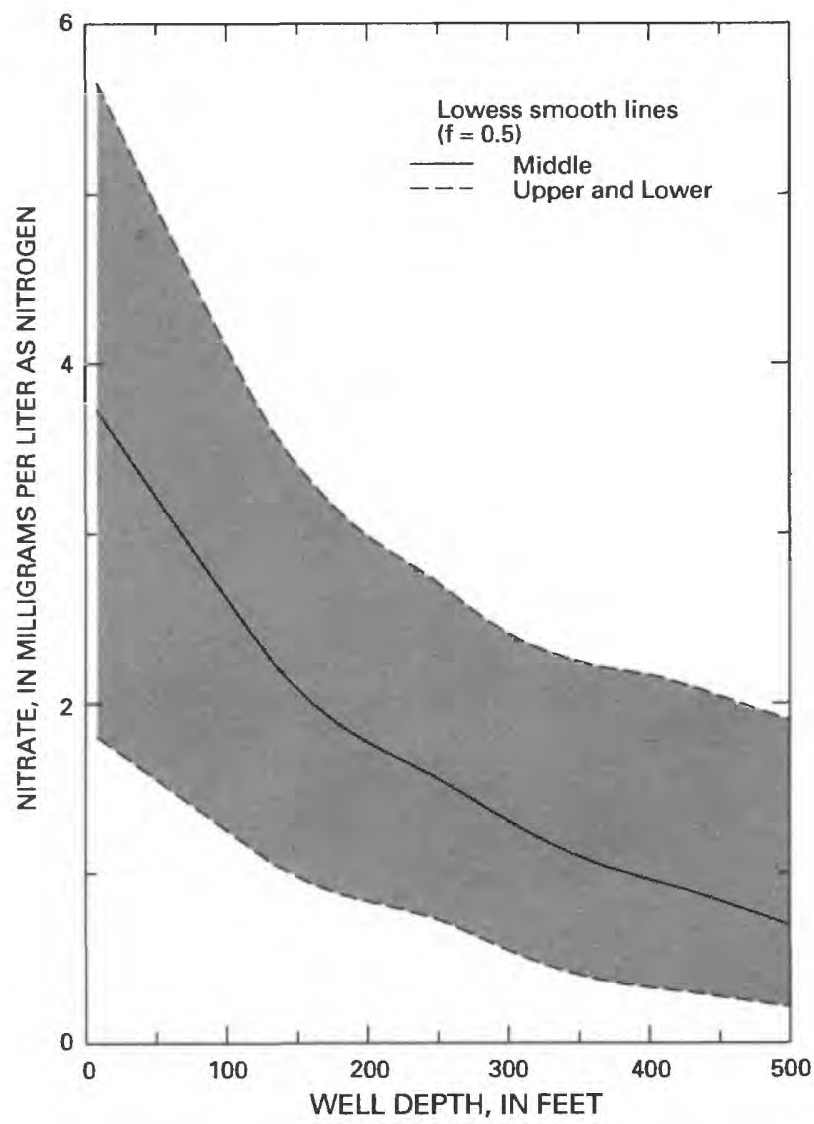

Figure 8. Relation between nitrate concentrations in ground water and well depth for samples in the national retrospective data set.

Table 10. Summary of nitrate concentrations by well depth in ground water beneath agricultural land

[mg/L, milligram per liter]

\begin{tabular}{|c|c|c|c|}
\hline \multirow[b]{2}{*}{$\begin{array}{l}\text { Well } \\
\text { depth }\end{array}$} & \multirow[b]{2}{*}{$\begin{array}{l}\text { Number } \\
\text { of wells }{ }^{1}\end{array}$} & \multicolumn{2}{|c|}{ Nitrate concentration } \\
\hline & & $\begin{array}{l}\text { Median } \\
\text { (mg/L) }\end{array}$ & $\begin{array}{c}\text { Exceeding } \\
\text { drinking-water } \\
\mathrm{MCL}^{2} \\
\text { (percent) }\end{array}$ \\
\hline $\begin{array}{l}\text { Less than or equal to } \\
100 \text { feet }\end{array}$ & 2,012 & 3.4 & 21.3 \\
\hline $\begin{array}{l}\text { Greater than } 100 \text { feet } \\
\text { through } 200 \text { feet }\end{array}$ & 1,326 & 1.8 & 9.8 \\
\hline $\begin{array}{l}\text { Greater than } 200 \text { feet } \\
\text { through } 300 \text { feet }\end{array}$ & 863 & 1.4 & 7.0 \\
\hline $\begin{array}{l}\text { Greater than } 300 \text { feet } \\
\text { through } 400 \text { feet }\end{array}$ & 394 & .80 & 3.0 \\
\hline $\begin{array}{l}\text { Greater than } 400 \text { feet } \\
\text { through } 500 \text { feet }\end{array}$ & 165 & .60 & 2.4 \\
\hline Greater than 500 feet & 675 & .10 & .74 \\
\hline
\end{tabular}




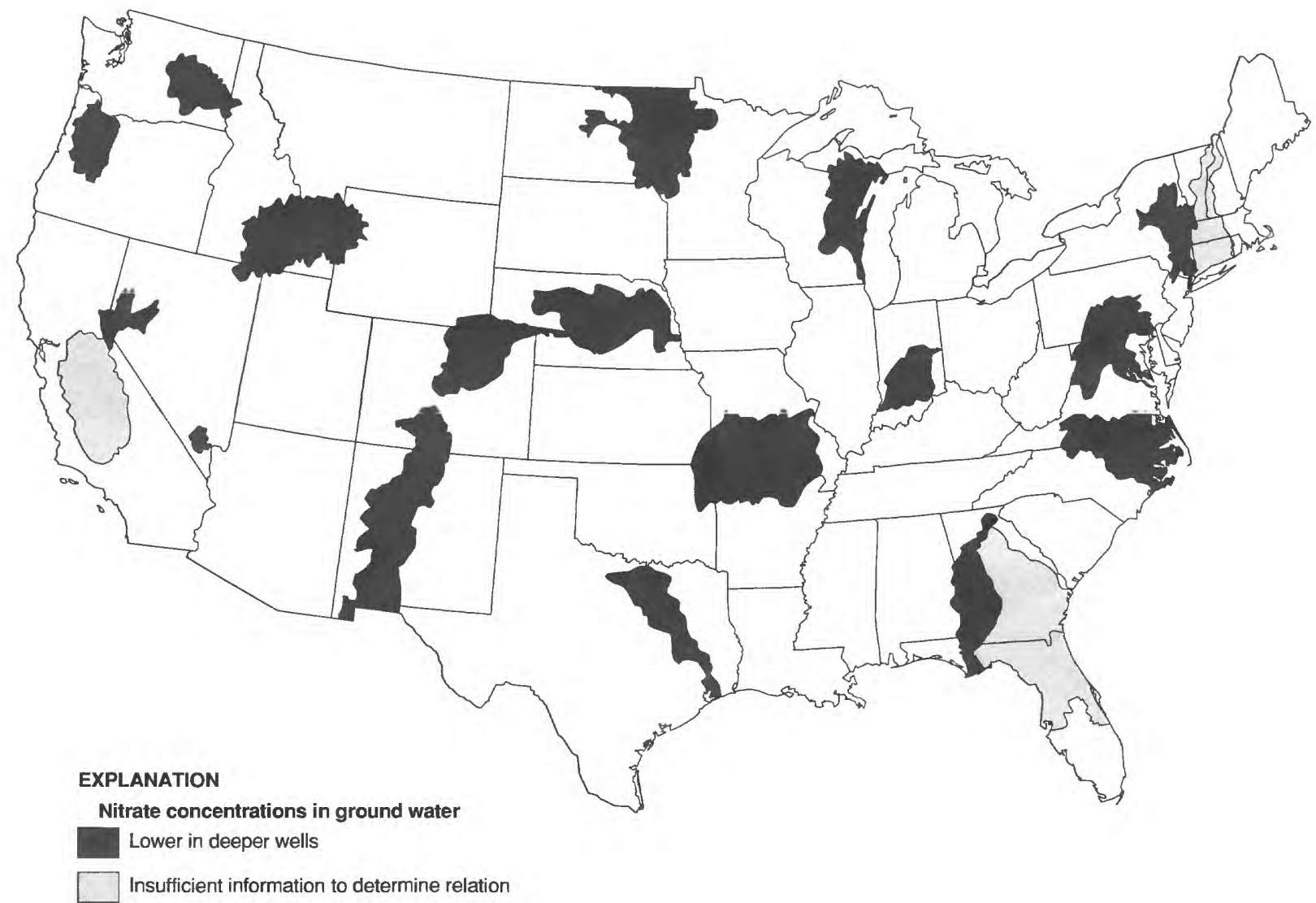

Figure 9. NAWQA study units where nitrate concentrations in ground water were related to well depth (refer to figure 1 for study-unit identification). 


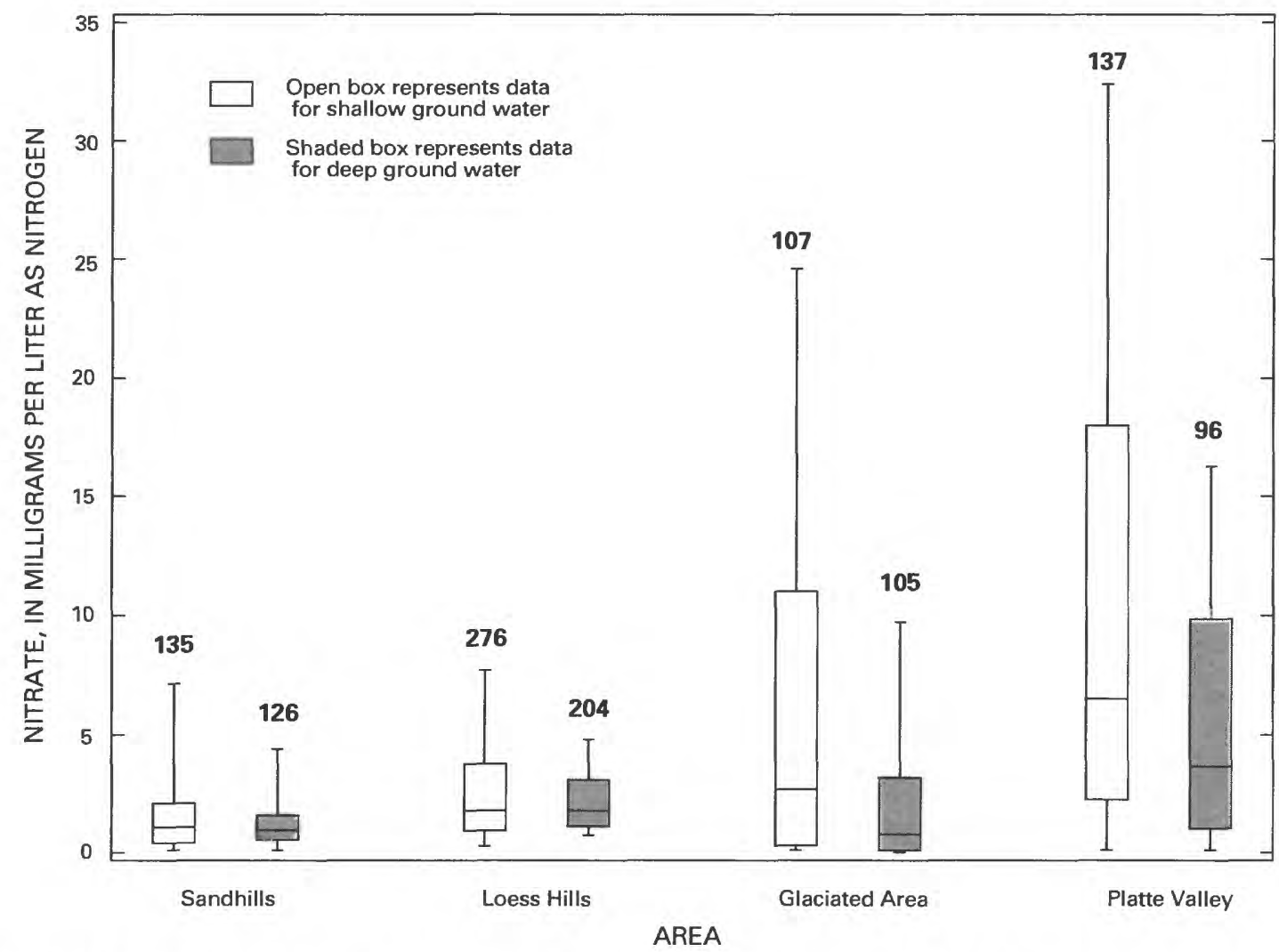

Figure 10. Nitrate concentrations in ground water from shallow and deep wells in various environmental settings, in the Central Nebraska Basins study unit (modified from Helgesen and others, 1994). 

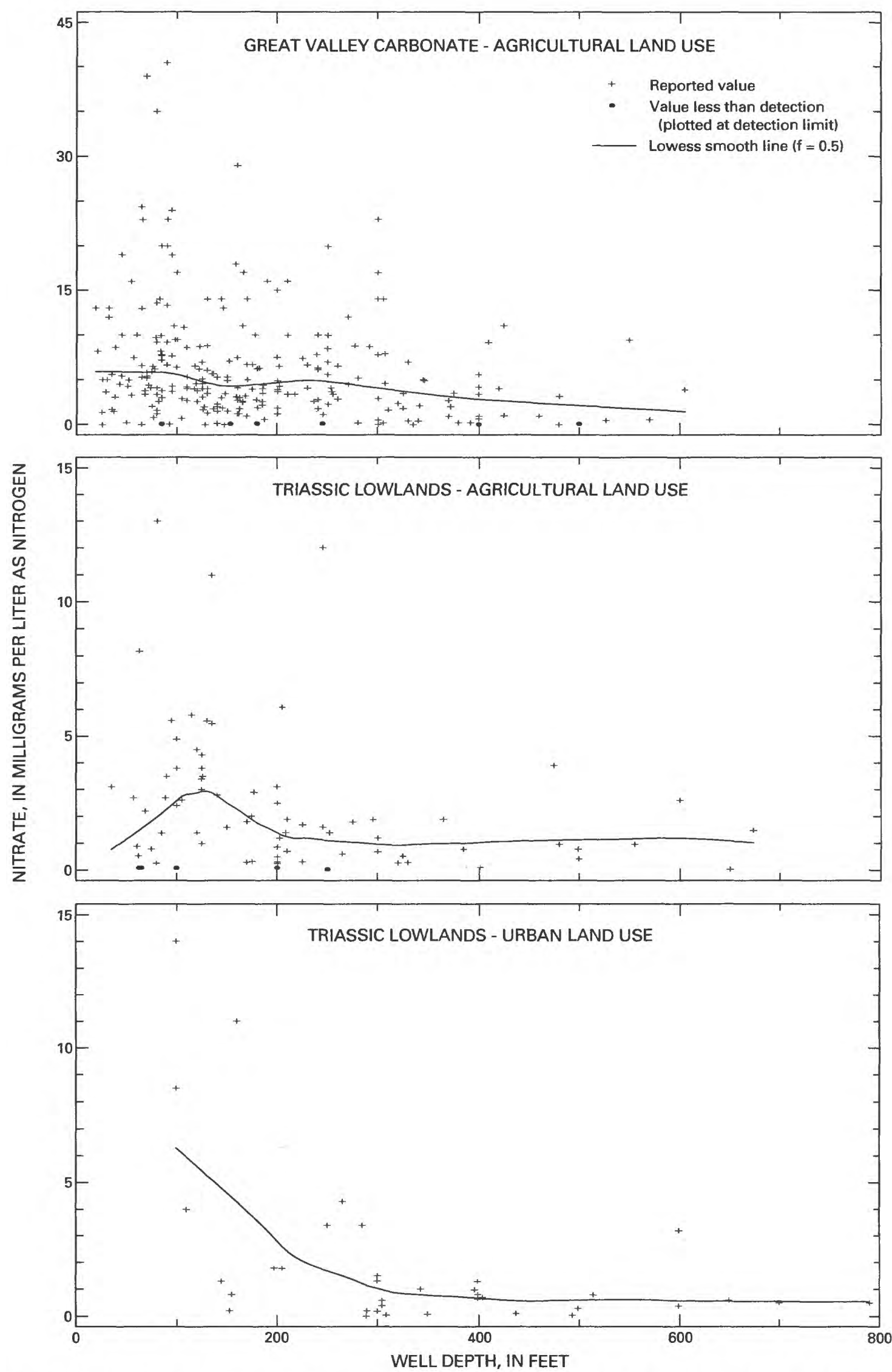

Figure 11. Relation between nitrite concentrations in ground water and well depth in the Potomac River Basin study unit (from J.S. Blomquist, U.S. Geological Survey, written commun., 1994). 


\section{Hydrogeologic Setting}

The type of geologic material through which ground water passes can strongly affect how easily water and nitrate can penetrate down to an aquifer. To investigate this, samples were classed into four broad hydrogeologic settings. Only data from Agricultural land-use settings were used, in order to remove differences due to land use. Nitrate concentrations differed significantly among the four hydrogeologic settings (fig. 12). Samples from alluvial aquifers in the Rio Grande study unit were excluded from the analysis shown in figure 12 . If the Rio Grande samples had been included, they would have dominated this setting ( 36 percent of the alluvial samples) and strongly biased the data towards their own characteristics. With the Rio Grande samples included, the distribution of nitrate concentrations in alluvial ground water would be significantly lower.

Nitrate concentrations were highest in unconsolidated sand and gravel aquifers, the setting with the highest permeability (fig. 12). Concentrations in alluvium and in carbonate bedrock were significantly less. These materials allow water to move somewhat less easily to the subsurface, though carbonate rocks can be fractured, providing quick connections to the subsurface. Concentrations in other less permeable bedrock, such as cemented sandstones and crystalline rocks, were lowest (table 11). In addition, nitrate concentrations are stable in aquifer materials containing measurable concentrations of dissolved oxygen. Higher dissolved-oxygen concentrations are commonly found in well-drained sand and gravel or in carbonate-rock fractures and solution channels. In areas underlain by impermeable bedrock or fine-grained sediment, poor drainage and a shallow water table can create anaerobic conditions that favor the production of ammonia at the expense of nitrate (Hamilton and others, 1993a).

In 13 of the 20 NAWQA study units, nitrate concentrations differed in ground water among various hydrogeologic settings (fig. 13). In study units where these differences did not occur, nitrate concentrations tended to be uniformly low. In the White study unit, nitrate concentrations were lowest in wells of the lowpermeability glacial-till aquifer (fig. 14). This was attributed to the greater difficulty for water to move down to the aquifer, and to denitrification of nitrate in the low-oxygen environment. Nitrate concentrations were also generally low in the bedrock aquifer but higher in the more permeable alluvium or outwash aquifers. Highest concentrations were found in the karst bedrock, where ample connections to the subsurface are available because of fractures and sinkholes. In the Lower Susquehanna study unit, median concentrations of nitrate were two to four times as high in carbonatebedrock units than in crystalline-bedrock areas. This difference was attributed in part to the intensive agricultural activity on land overlying the carbonate settings, but also to the good connection to the subsurface typical of fractured carbonate rocks.

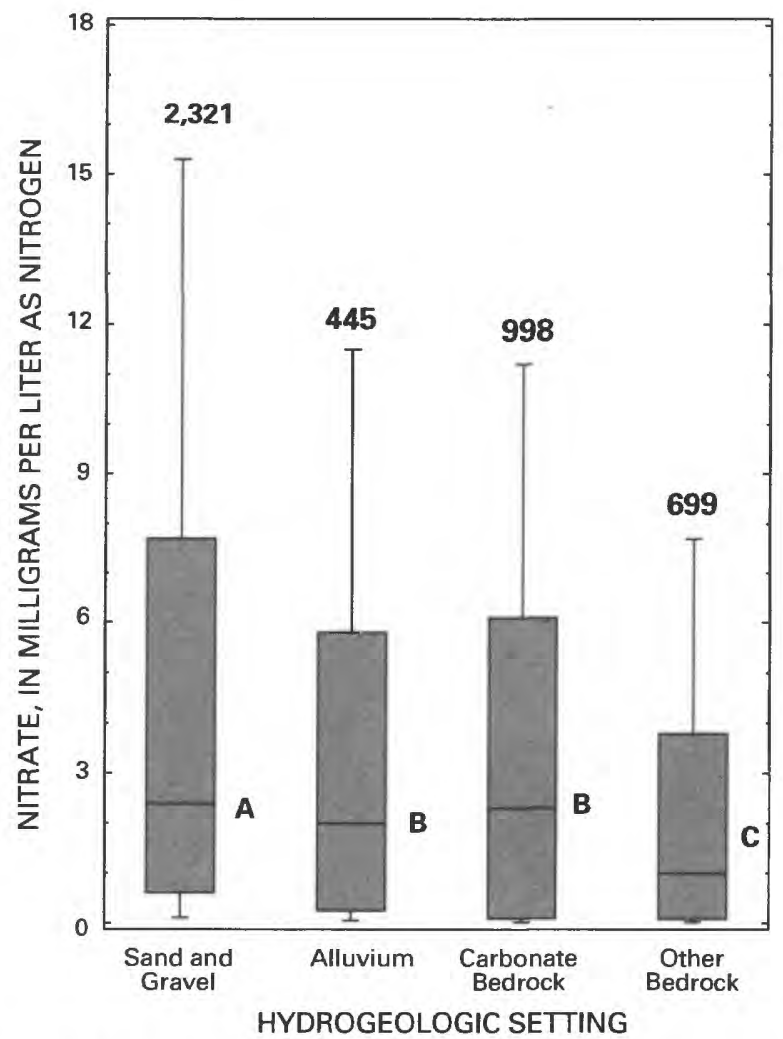

Figure 12. Nitrate concentrations in ground water beneath agricultural land in different hydrogeologic settings for samples in the national retrospective data set.

Table 11. Summary of nitrate concentrations by hydrogeologic setting in ground water beneath agricultural land

[mg/L, milligram per liter]

\begin{tabular}{|c|c|c|c|}
\hline \multirow[b]{2}{*}{$\begin{array}{l}\text { Hydro- } \\
\text { geologic } \\
\text { setting }{ }^{1}\end{array}$} & \multirow[b]{2}{*}{$\begin{array}{l}\text { Number } \\
\text { of wells }\end{array}$} & \multicolumn{2}{|c|}{ Nitrate concentration } \\
\hline & & $\begin{array}{l}\text { Median } \\
\text { (mg/L) }\end{array}$ & $\begin{array}{c}\text { Exceeding } \\
\text { drinking-water } \\
\text { MCL }^{3} \\
\text { (percent) }\end{array}$ \\
\hline $\begin{array}{l}\text { Unconsolidated sand } \\
\text { and gravel }\end{array}$ & 2,321 & 2.4 & 17.1 \\
\hline Alluvium ${ }^{4}$ & 445 & 2.0 & 11.9 \\
\hline Glacial till & 29 & 1.5 & 27.6 \\
\hline Basalt & 55 & 1.8 & 12.7 \\
\hline Carbonate bedrock & 998 & 2.3 & 11.4 \\
\hline Other bedrock ${ }^{5}$ & 699 & 1.0 & 5.2 \\
\hline $\begin{array}{l}\text { Trom description } \\
\text { (GWSI) data base. } \\
{ }^{2} \text { One sample used } \\
{ }^{3} \text { Maximum conta } \\
\text { Protection Agency, } 1990 \\
{ }^{4} \text { Data from } 255 \text { we } \\
{ }^{5} \text { Includes cemente }\end{array}$ & $\begin{array}{l}\text { in the USC } \\
\text { ner well. } \\
\text { ninant level } \\
\text { Is in the Rio } \\
\text { sandstones, }\end{array}$ & $\begin{array}{l}\text { S Ground- } \\
(10 \mathrm{mg} / \mathrm{L} \text {, } \\
\text { irande Valle } \\
\text { hale, silicic }\end{array}$ & $\begin{array}{l}\text { ater Site Inventory } \\
\text { U.S. Environmental } \\
\text { study unit excluded. } \\
\text { stics, and crystalline }\end{array}$ \\
\hline
\end{tabular}




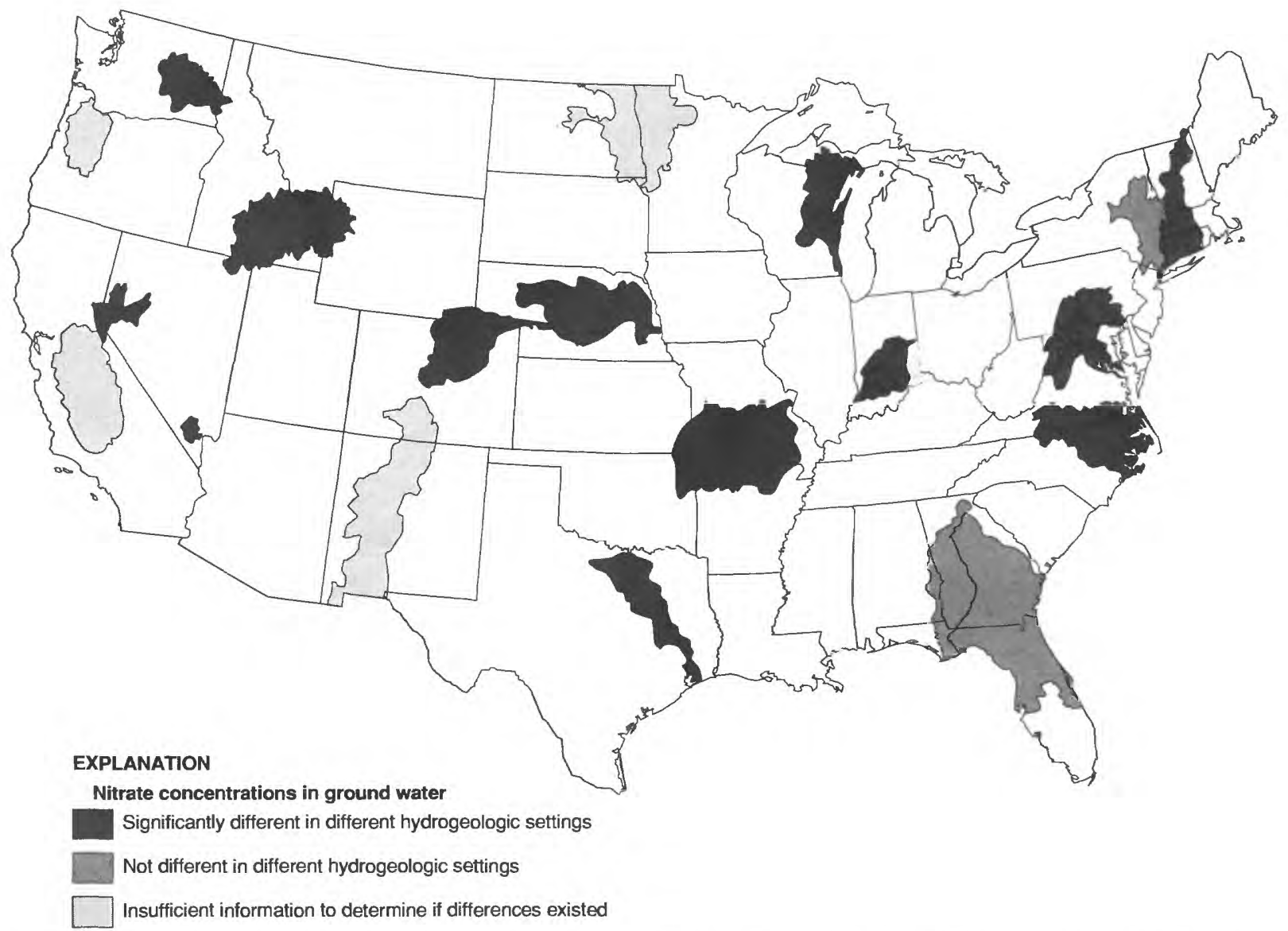

Figure 13. NAWQA study units where nitrate concentrations in ground water were related to hydrogeologic setting (refer to figure 1 for study-unit identification). 


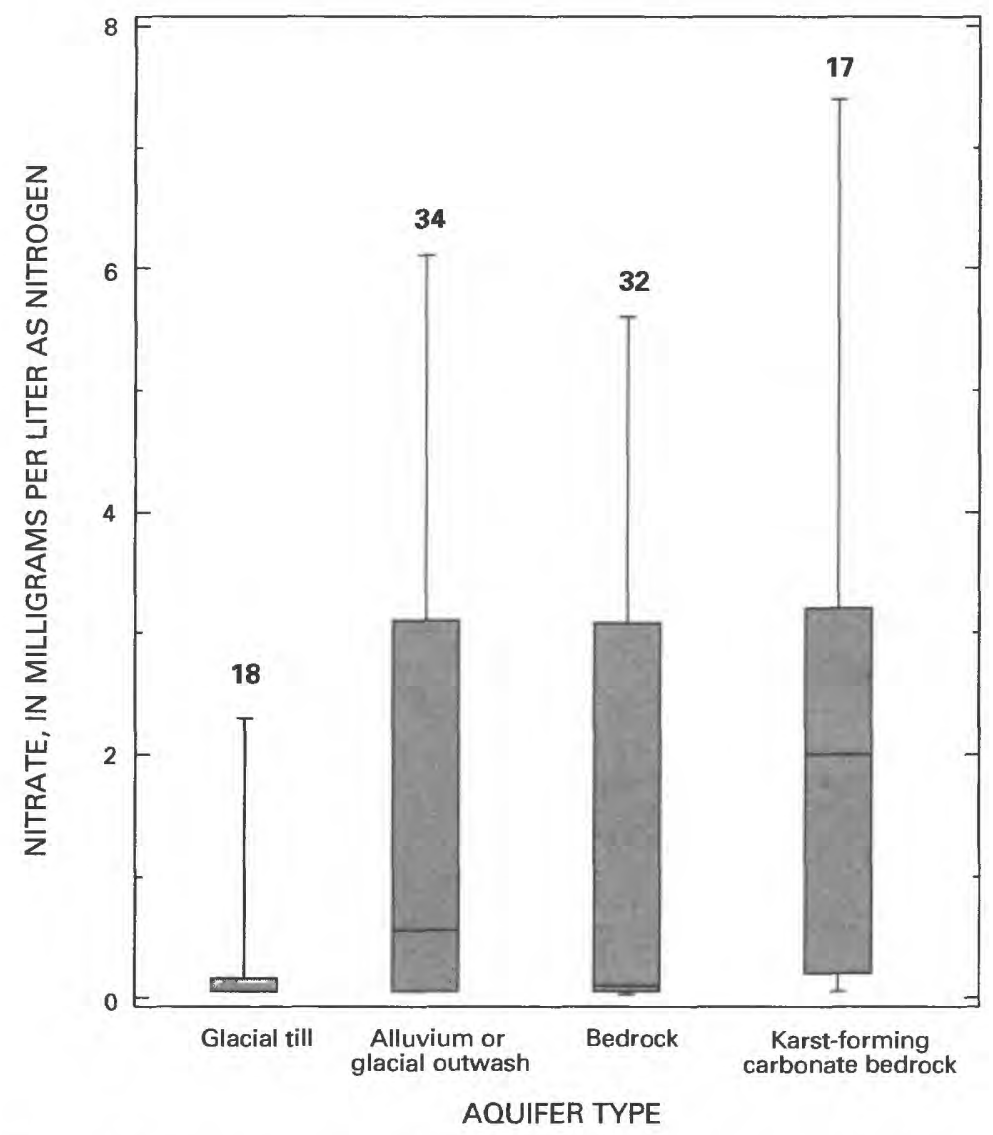

Figure 14. Nitrate concentrations in ground water for various hydrogeologic settings in the White River Basin study unit (from J.D. Martin, U.S. Geological Survey, written commun., 1994). 


\section{Soil Hydrologic Group}

The ability of soil to transmit water and oxygen may have a similar effect on ground-water quality, particularly for shallow systems. To investigate this, data from wells less than 100 feet in depth within agricultural areas were studied in the national retrospective data set. Nitrate concentrations differed significantly in ground water beneath different soils, classified by the soil hydrologic group (fig. 15). Concentrations were highest beneath the two well-drained soils categories (groups A and B). Median concentrations ranged from $4.7 \mathrm{mg} / \mathrm{L}$ in ground water beneath group A soils to $0.17 \mathrm{mg} / \mathrm{L}$ in ground water beneath poorly drained soils in group D (table 12). Soils in hydrologic groups $\mathrm{C}$ and D commonly contain fine-grained material that is less permeable and transmits water at slower rates than the more permeable and better drained soils in groups A and B. This impedes movement of nitrate to the subsurface in several ways. First, fine-grained deposits retard the downward movement of water, and therefore of nitrate, to ground water. Second, poorly drained soils are usually anaerobic, favoring ammonia as the stable form of nitrogen (Hamilton and others, 1993a) and so preventing nitrate from forming. Third, tile drains or ditches are often used in poorly drained agricultural fields to remove excess water from the soil. This prevents some nitrate from ever reaching ground water, instead directing it into nearby streams.

In 5 of the 20 NAWQA study units, nitrate concentrations differed in ground water beneath different types of soil. The other 15 study units were not able to evaluate this relationship but did provide their data for the national analysis. In the Central Columbia study unit, median nitrate concentrations were more than twice as high in samples from areas of coarse, alluvial sand (Quincy-Pasco area) as in samples from areas of basalt-derived (North-Central area) or loess-derived (Palouse area) soils (fig. 16). Concentrations exceeded the drinking-water MCL three times more frequently in the Quincy-Pasco area than in the other two areas. Agricultural activity is more intense in the QuincyPasco area, with considerably higher fertilizer application and irrigation rates than in the North-Central or Palouse areas. The high transmissivity of soils in the Quincy-Pasco area requires frequent fertilization and irrigation, providing both a source and easy access to the subsurface. Because of the tighter, clay-rich soils in the Palouse area, more nitrate is removed in stream runoff or by crops, and less nitrate penetrates the thick, low-permeability unsaturated zone to reach ground water (Jones and Wagner, in press).

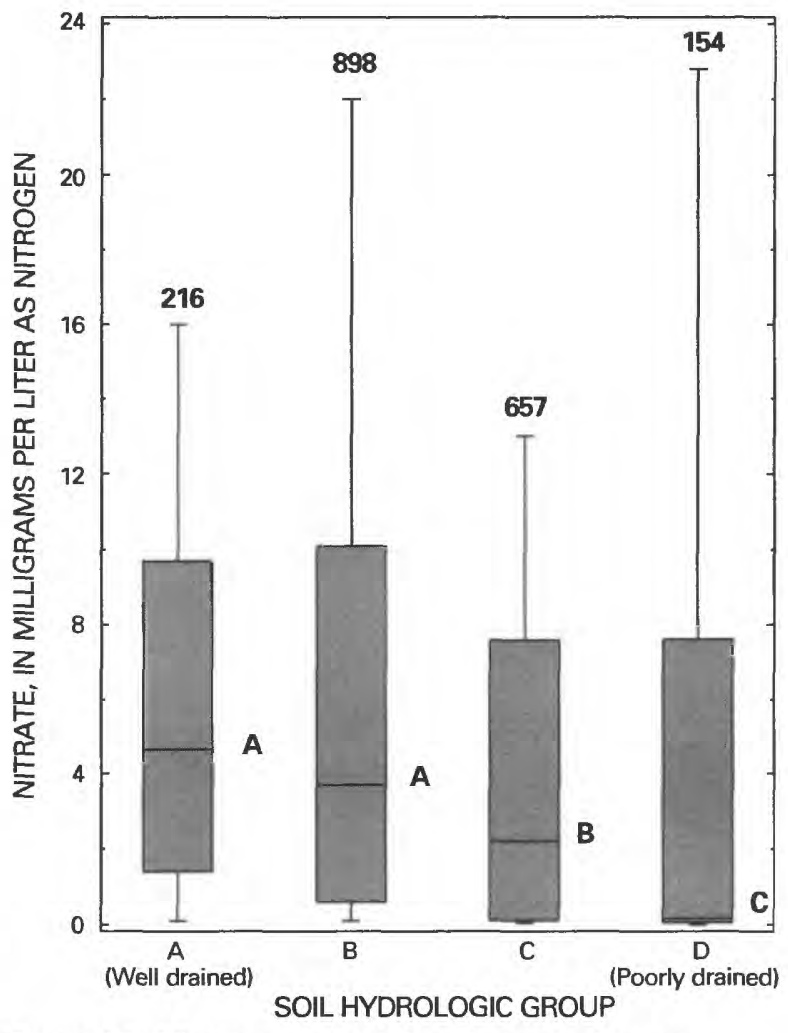

Figure 15. Nitrate concentrations in ground water beneath agricultural land in different soil hydrologic groups for samples in the national retrospective data set.

Table 12. Summary of nitrate concentrations by soil hydrologic group in ground water beneath agricultural land

[mg/L, milligram per liter]

\begin{tabular}{|c|c|c|c|}
\hline \multirow[b]{2}{*}{$\begin{array}{l}\text { Soll } \\
\text { hydrologic } \\
\text { group }\end{array}$} & \multirow[b]{2}{*}{$\begin{array}{l}\text { Number } \\
\text { of wells }\end{array}$} & \multicolumn{2}{|c|}{ Nitrate concentration } \\
\hline & & $\begin{array}{l}\text { Median } \\
\text { (mg/L) }\end{array}$ & $\begin{array}{c}\text { Exceeding } \\
\text { drinking-water } \\
\text { MCL }^{3} \\
\text { (percent) }\end{array}$ \\
\hline A (well drained) & 216 & 4.7 & 21.8 \\
\hline B & 898 & 3.7 & 25.2 \\
\hline $\mathrm{C}$ & 657 & 2.2 & 14.8 \\
\hline $\mathrm{D}$ (poorly drained) & 154 & 0.17 & 20.8 \\
\hline
\end{tabular}




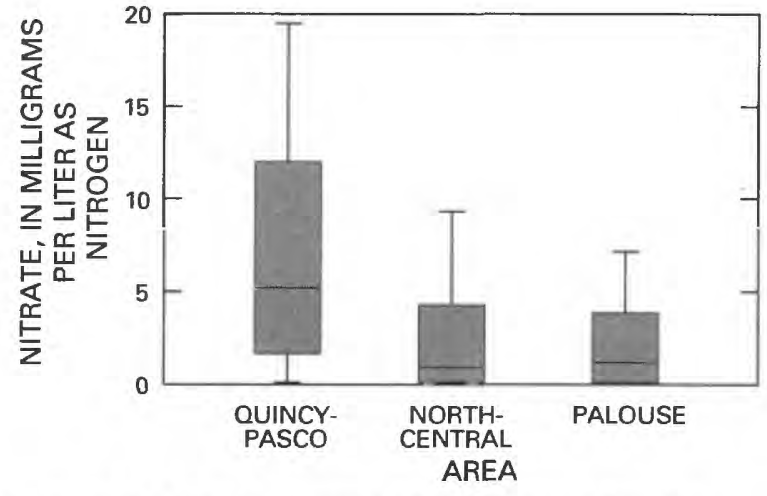

Figure 16. Nitrate concentrations in ground water from different areas in the Central Columbia Plateau study unit (from Jones and Wagner, in press).

Soils were also a factor affecting nitrate concentrations of ground water within the Central Nebraska study unit (Helgesen and others, 1994). Highest median nitrate concentrations occurred in ground water under the permeable soils of the Platte Valley. This is also where irrigation is most intensively practiced, due to the low water-retention capacity of these sandy soils.
In comparison, soils in the glaciated area of this study unit contain more clay, irrigation is less intense, and nitrate concentrations in ground water were significantly lower. The relationship between high nitrate in Nebraska ground water and intense irrigation also has been identified by Chen and Druliner (1987). Although it is difficult to separate the effects of soil and irrigation, soil conditions are a major determinant of where irrigation is required, and therefore, of where nitrate concentrations are likely to be high in ground water.

Soils of the W. Lake Michigan study unit vary from sandy soils with interspersed sands and gravels to clay-rich soils that have high moisture-retention capacities. Median nitrate concentrations in ground water were higher in areas of sandy soil (fig. 17), and ammonia concentrations were correspondingly lower. In figure 17 , soil permeability increases from left to right, as do median nitrate concentrations. Because water moves more quickly downward after fertilizer application in sandy soils, more fertilizer is generally applied in those areas as well.

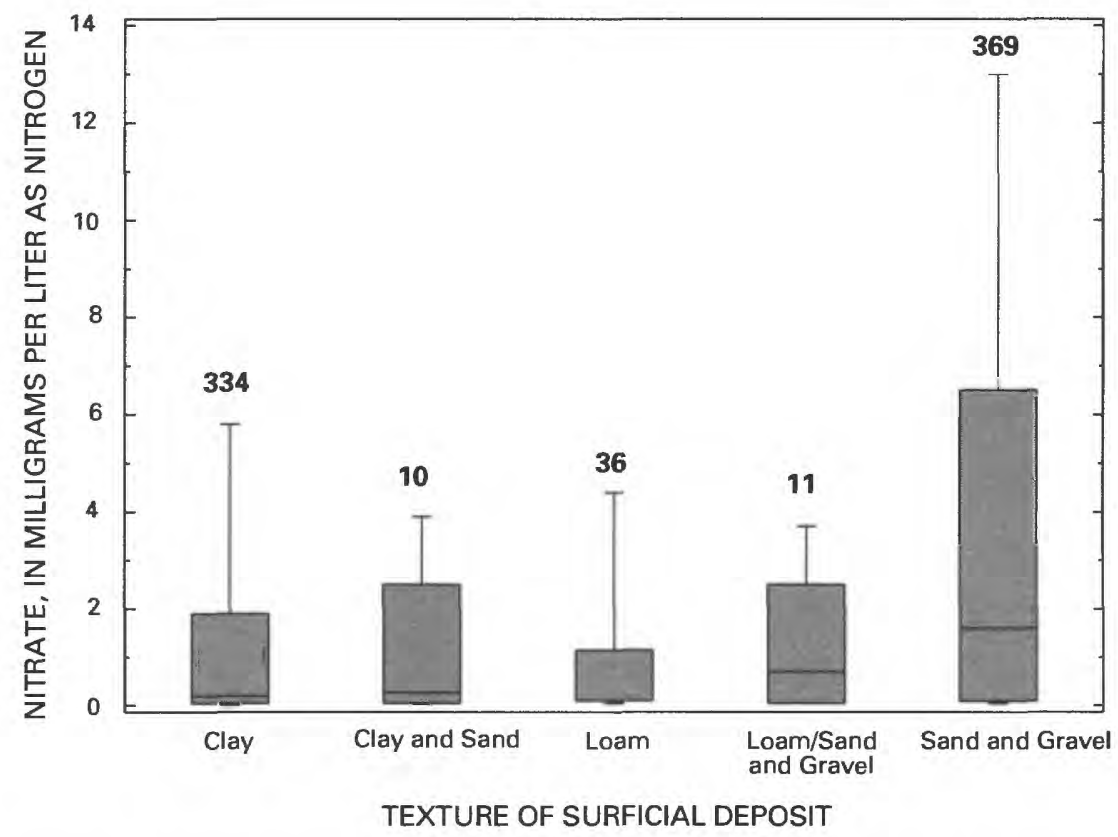

Figure 17. Nitrate concentrations in ground water beneath various soil types in the Western Lake Michigan Drainages study unit (from D.M. Robertson, U.S. Geological Survey, written commun., 1994). 


\section{Depth to Water}

Ground waters in areas where the distance between the land surface and the saturated zone is moderate (shallow depth to water) generally have higher nutrient concentrations than those in areas where this distance is large. Depth to water is an indicator of the vulnerability of the aquifer to contamination from the surface and differs from the previously discussed depth of the well because it does not count the distance below the top of the water table down to the well screen. The relation between depth to water and nitrate concentration in samples under agricultural areas in the national data set is shown in figure 18. In apparent contradiction to the general rule given above, nitrate concentrations were generally lowest at sites where the depth to water was less than 5 feet below land surface (table 13). In these areas, soils are usually poorly drained and anaerobic. These conditions favor ammonia, rather than nitrate, as the predominant nitrogen species (Hamilton and

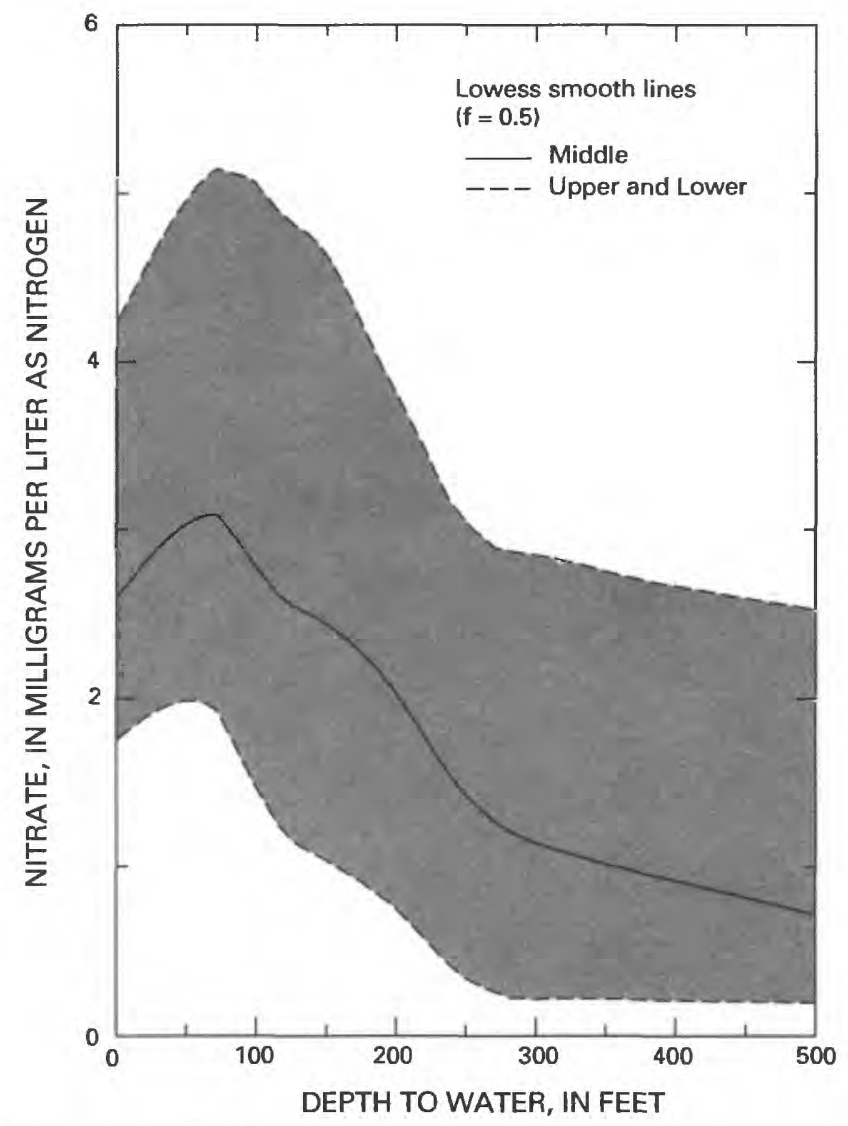

Figure 18. Relation between nitrate concentrations in ground water and depth to water for samples in the national retrospective data set. others, 1993a). Nitrate concentrations were highest in well-drained areas underlain by a water table about 80-100 feet below land surface. Concentrations were lower where depths to water exceeded 100 feet, possibly because of the increased potential for denitrification.

Several NAWQA study units reported similar results. For example, within the Upper Snake study unit, nitrate concentrations generally increased as depths to water increased from 0 to 100 feet, and then decreased with larger depths to water. The decrease as depth to water increased greater than 100 feet was attributed to denitrification and other subsurface processes. More ammonia data are required before evaluation of the processes for decreased nitrate at the shallowest depths to water can be investigated. In the Connecticut study unit, high nitrate concentrations observed in glacial-till aquifers were attributed in part to shallow depths to water because of vulnerability to contamination from the surface.

Table 13. Summary of nitrate concentrations by depth to water in ground water beneath agricultural land

[mg/L, milligram per liter]

\begin{tabular}{|c|c|c|c|}
\hline \multirow[b]{2}{*}{$\begin{array}{l}\text { Depth } \\
\text { to water }\end{array}$} & \multirow[b]{2}{*}{$\begin{array}{l}\text { Number } \\
\text { of wells }\end{array}$} & \multicolumn{2}{|c|}{ Nitrate concentration } \\
\hline & & $\begin{array}{l}\text { Median } \\
(\mathrm{mg} / \mathrm{L})\end{array}$ & $\begin{array}{c}\text { Exceeding } \\
\text { drinking-water } \\
\text { MCL }^{2} \\
\text { (percent) }\end{array}$ \\
\hline $\begin{array}{l}\text { Less than or equal to } \\
5 \text { feet }\end{array}$ & 129 & 0.70 & 8.8 \\
\hline $\begin{array}{l}\text { Greater than } 5 \text { feet } \\
\text { through } 10 \text { feet }\end{array}$ & 309 & 2.0 & 19.0 \\
\hline $\begin{array}{l}\text { Greater than } 10 \text { feet } \\
\text { through } 25 \text { feet }\end{array}$ & 458 & 2.5 & 15.5 \\
\hline $\begin{array}{c}\text { Greater than } 25 \text { feet } \\
\text { through } 50 \text { feet }\end{array}$ & 468 & 3.4 & 17.3 \\
\hline $\begin{array}{l}\text { Greater than } 50 \text { feet } \\
\text { through } 100 \text { feet }\end{array}$ & 365 & 3.2 & 11.7 \\
\hline $\begin{array}{l}\text { Greater than } 100 \text { feet } \\
\text { through } 150 \text { feet }\end{array}$ & 123 & 1.9 & 4.7 \\
\hline Greater than 150 feet & 225 & .80 & 3.9 \\
\hline
\end{tabular}


Low nitrate concentrations in aquifers with very shallow depths to water occurred in waterlogged areas of the coastal plain in the Albemarle-Pamlico study unit. The outer coastal plain, with the shallowest depths to water and greatest proportion of wetlands, exhibited the lowest dissolved-oxygen conditions and low nitrate concentrations (fig. 19), but high ammonia concentrations. The sandier soils of the inner coastal plain allowed dissolved oxygen to enter more deeply into ground water, resulting in higher nitrate and lower ammonia concentrations.

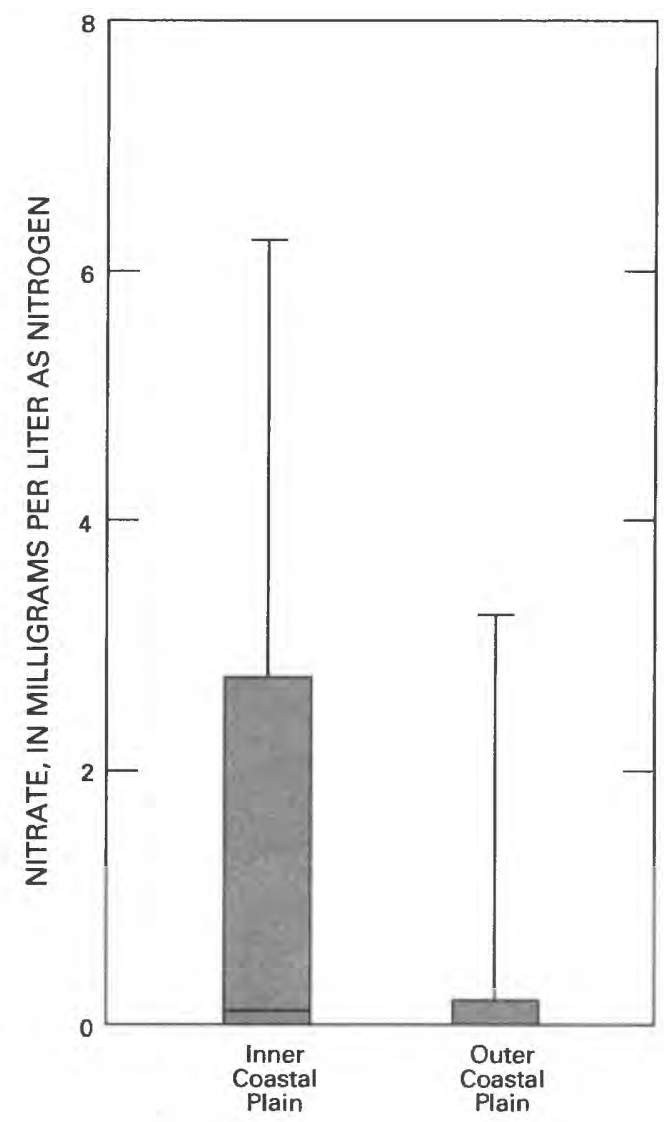

Figure 19. Nitrate concentrations in ground water from two coastal zones in the AlbemarlePamlico Drainage study unit (modified from Harned and others, in press).

\section{Type of Agricultural Land Use}

Different types of on-farmland use are combined in the GIRAS Agricultural Land category. But, the Census of Agriculture (U.S. Bureau of the Census, 1989) differentiates among the percentages of cropland, pasture, and woodland for each county in the Nation. Pasture and woodland generally receive less intensive fertilizer and manure applications than does cropland. Data from this census were used to evaluate the effects of mixed agricultural land use. The inter- spersion of various agricultural land uses at groundwater sampling sites in the national retrospective data set was identified by the ratios of pasture or woodland to cropland within the county where the sites were located. In this analysis, pasture does not include grazed rangeland, and woodland is defined as grazed or ungrazed stands of trees in agricultural areas; large tracts of forest are not included. Analysis was limited to samples collected within 100 feet of land surface to better represent the effects of land use and human activities at the surface. Distributions of nitrate in ground water associated with incremental ratios of pasture and woodland to cropland are shown in figure 20 , and median concentrations are listed in table 14. Nitrate concentrations were significantly higher in ground water beneath areas where the ratio of pasture to cropland was less than or equal to 1 (fig. 20A), or where the ratio of woodland to cropland was less than or equal to 0.2 (fig. 20B).

Extensive application of fertilizer and manure on large tracts of cropland increases the likelihood of nitrogen entering the ground-water system. The likelihood decreases in areas where pasture or woodland constitutes a large part of the agricultural land use because far less nitrogen is generally applied to pasture and woodland areas. Vegetative uptake and denitrification within poorly drained soils might result in low nitrate concentrations in recharge water from wooded areas (Spalding and Exner, 1993). In cropland with a high degree of interspersed woodlands, low-nitrate water recharged through poorly drained woodland soils can dilute high-nitrate water recharged from cropland (Hamilton and others, 1993a).

The amount of woodland interspersed with cropland can be indicative of related factors, such as soil characteristics, hydrology, and geomorphology, that also affect nitrate distribution. For example, Hamilton and others (1993a) reported that several related factors in the central and western fringes of the Delmarva Peninsula (Delmarva study area) explained low nitrate concentrations. That area is underlain by poorly drained and fine-grained sediments that are poorly incised by sluggish and low-gradient streams. Agricultural plots are relatively small and have a high percentage of interspersed woodland. This land-use pattern is in contrast to agricultural areas in the northern and southern tip of the peninsula, where nitrate concentrations were significantly higher. These areas are underlain by permeable soils and sediments that are deeply incised by stream valleys and a deeper water table than in the poorly drained areas. In these well-drained areas, agricultural plots are large and woodlands primarily are confined to borders along streams. 

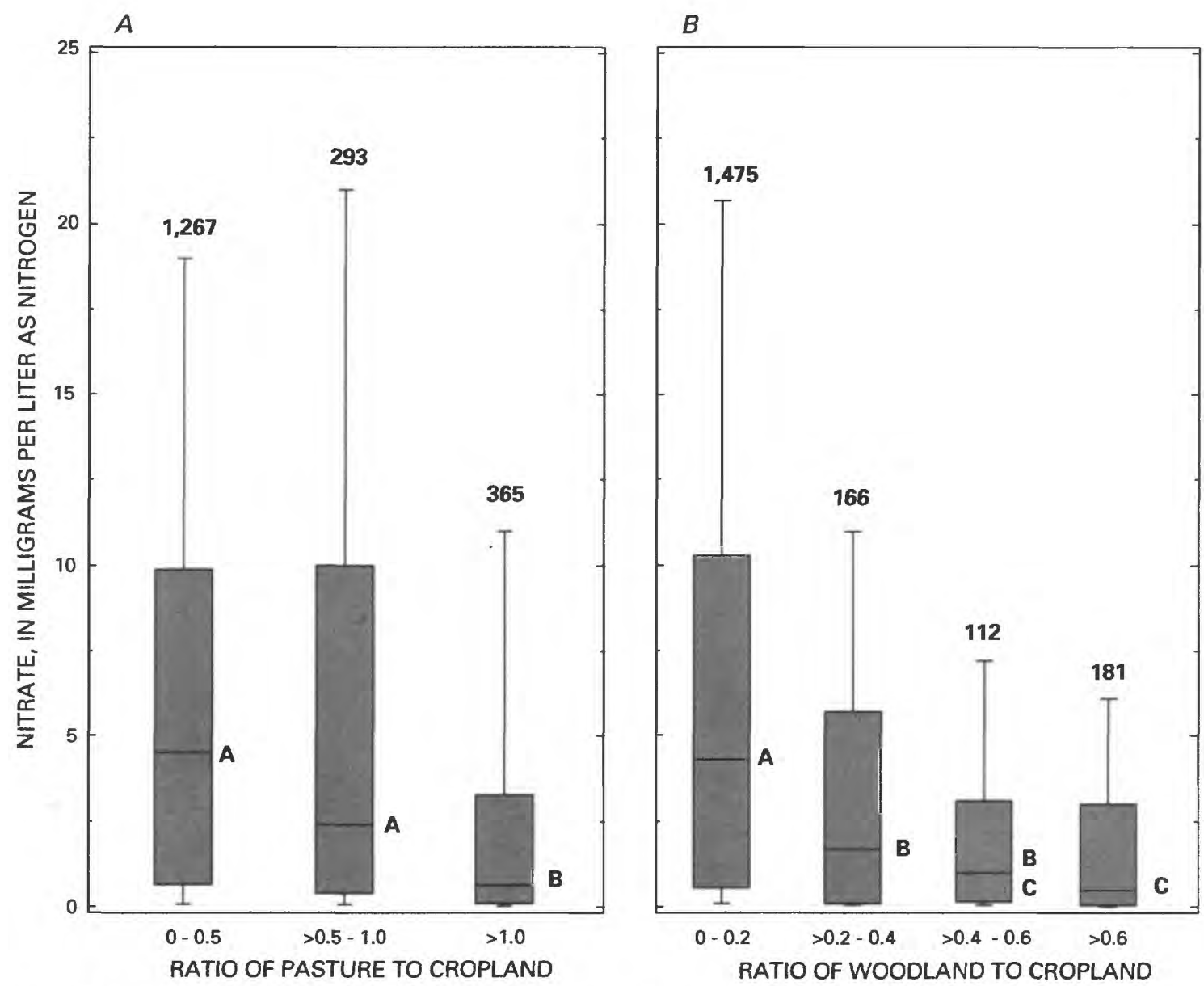

Figure 20. Nitrate concentrations in ground water beneath agricultural land by incremental ratios of (A) pasture, and (B) woodland on farms to cropland for samples in the national retrospective data set.

Table 14. Summary of nitrate concentrations by ratio of pasture or woodland on farms to cropland in ground water beneath agricultural land

[mg/L, milligram per liter]

\begin{tabular}{|c|c|c|c|}
\hline \multirow[b]{2}{*}{$\begin{array}{l}\text { Ratio of other agricultural } \\
\text { land use to cropland }\end{array}$} & \multirow[b]{2}{*}{$\begin{array}{l}\text { Number } \\
\text { of wells }\end{array}$} & \multicolumn{2}{|c|}{ Nitrate concentration } \\
\hline & & $\begin{array}{l}\text { Median } \\
\text { (mg/L) }\end{array}$ & $\begin{array}{c}\text { Exceeding } \\
\text { drInking-water } \\
\text { MCL }^{3} \\
\text { (percent) }\end{array}$ \\
\hline \multicolumn{4}{|c|}{ Pasture } \\
\hline Less than or equal to 0.50 & 1,267 & 4.4 & 22.8 \\
\hline Greater than 0.50 and less than or equal to 1.0 & 293 & 2.4 & 24.9 \\
\hline Greater than 1.0 & 365 & 0.64 & 11.5 \\
\hline \multicolumn{4}{|c|}{ Woodland on farms } \\
\hline Less than or equal to 0.20 & 1,475 & 4.3 & 25.2 \\
\hline Greater than 0.20 and less than or equal to 0.40 & 166 & 1.7 & 10.2 \\
\hline Greater than 0.40 and less than or equal to 0.60 & 112 & 1.0 & 7.1 \\
\hline Greater than 0.60 & 181 & .49 & 5.5 \\
\hline
\end{tabular}




\section{Spatial Distribution of Nitrate Concentrations in Ground Water Beneath Agricultural Land}

Factors affecting ground-water quality differ across broad (multi-State) regions of the Nation. It would not be surprising, therefore, if broad regional patterns in the quality of ground water were also evident. To investigate this, all but three study units were grouped into the State-based regions of Spalding and Exner (1991) shown in figure 21. Two study units could not fit into this convenient classification because State boundaries do not always follow watershed and geomorphological divisions. The Ozark study unit overlapped four regions and was not considered representative of any one of them. The South Platte study unit is classified in the Mountain States region, but most samples were collected on the plains of eastern Colorado, which are more representative of the Northern Plains region. The Trinity was not included because it was the only study unit in the Southern Plains States, and it did not cover enough area or have enough samples to adequately represent that region.

Median nitrate concentrations in ground water from agricultural sites within the national retrospective data set are listed by region and study unit in table 15 , as are the number and percentage of samples that exceeded 3 and $10 \mathrm{mg} / \mathrm{L}$. Nitrate concentrations greater than $3 \mathrm{mg} / \mathrm{L}$ in ground water may indicate effects of human activities (Madison and Brunett, 1985); concentrations greater than $10 \mathrm{mg} / \mathrm{L}$ exceed the drinking-water MCL (U.S. Environmental Protection Agency, 1990b). Nitrate concentrations exceeded $3 \mathrm{mg} / \mathrm{L}$ in about 50 percent, and exceeded $10 \mathrm{mg} / \mathrm{L}$ in about 21 percent, of the agricultural wells.

Nitrate concentrations were significantly higher in samples from NAWQA study units and supplemental study areas in the Northeastern, Northern Plains, and Pacific States than in samples from other regions (fig. 22). These findings are consistent with national reviews of more than 200,000 nitrate analyses by Spalding and Exner $(1991,1993)$ and national summaries by Hallberg (1989) and Hallberg and Keeney (1993).
Several factors can explain this regional distribution of nitrate in shallow ground water beneath agricultural areas, including soil characteristics, land use, and hydrogeologic conditions. Each region has distinguishing features, such as soil composition, or other areal attributes that impart a characteristic set of waterquality patterns. The relative importance of these features varies from region to region.

\section{Northeastern States}

The median nitrate concentration in groundwater samples from the Northeastern States was significantly greater than in samples from all other regions except the Northern Plains and the Pacific States (fig. 22). Based on the 3-mg/L criterion, about 58 percent of the samples from these regions indicated effects of human activities, and almost 20 percent had nitrate concentrations in excess of the drinking-water MCL (table 15).

Agriculture in this region is primarily row crops. The ratio of pasture to cropland is significantly less than in any other region except the Corn Belt and Lake States (fig. 23B). Application of manure on croplands is extensive in the Northeastern States (Puckett, 1994). Much of the agricultural land in this region is underlain by permeable material, such as alluvium, carbonate bedrock, or unconsolidated sand and gravel. Water and dissolved nutrients can readily move downward to the water table.

\section{Appalachian and Southeastern States}

Nitrate concentrations were lower in groundwater samples from the Appalachian and Southeastern States than in samples from any other region (fig. 22). Effects from human activities were indicated in only about 16 percent of the samples, and the MCL was exceeded in only 2 percent (table 15 ). These low concentrations were observed despite extensive fertilizer use (Kellogg and others, 1992) and, in some locations, well-drained, sandy soils (fig. 23A). These results are consistent with previous findings (Spalding and Exner, 1993; Hubbard and Sheridan, 1989). Hubbard and Sheridan reported few incidences of ground-water nitrate contamination in this region, despite the large annual rainfall and sometimes sandy soils, which require heavy applications of fertilizer. 


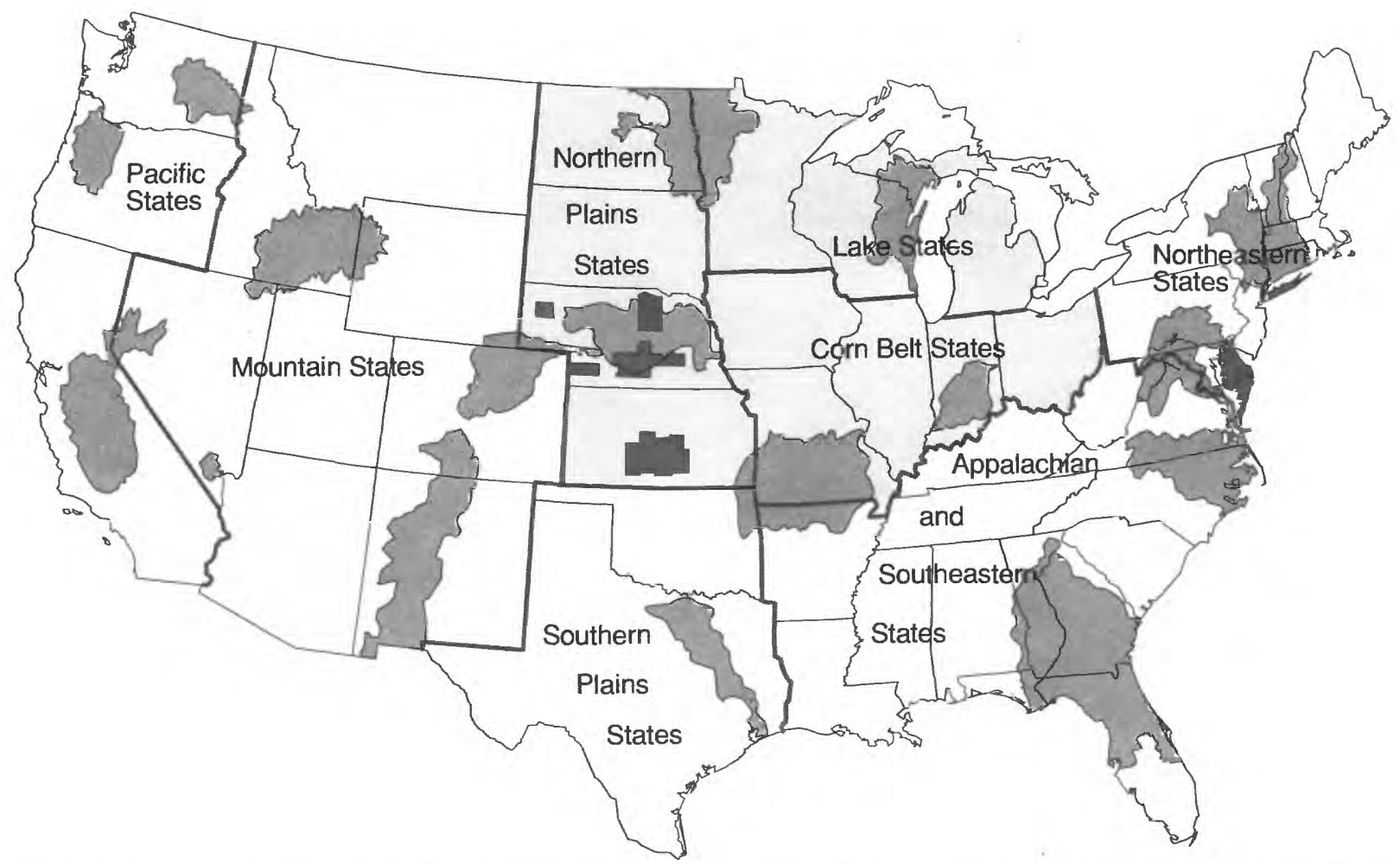

Figure 21. Geographical regions of the United States (as defined by Spalding and Exner, 1991; refer to figure 1 for study-unit and study-area identification). 
Table 15. Summary of nitrate concentrations by geographic region ${ }^{1}$ in ground water beneath agricultural land [mg/L, milligram per liter]

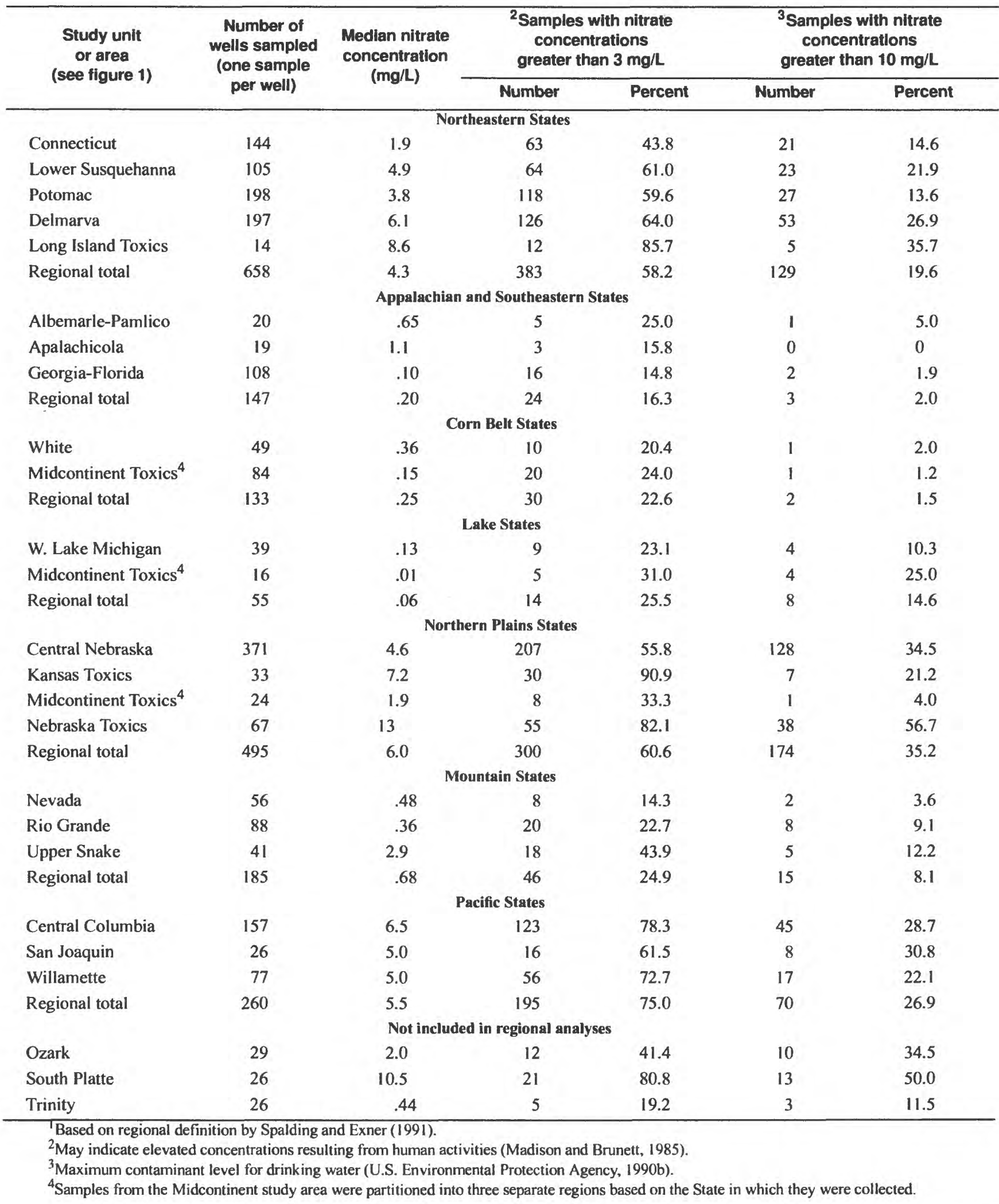




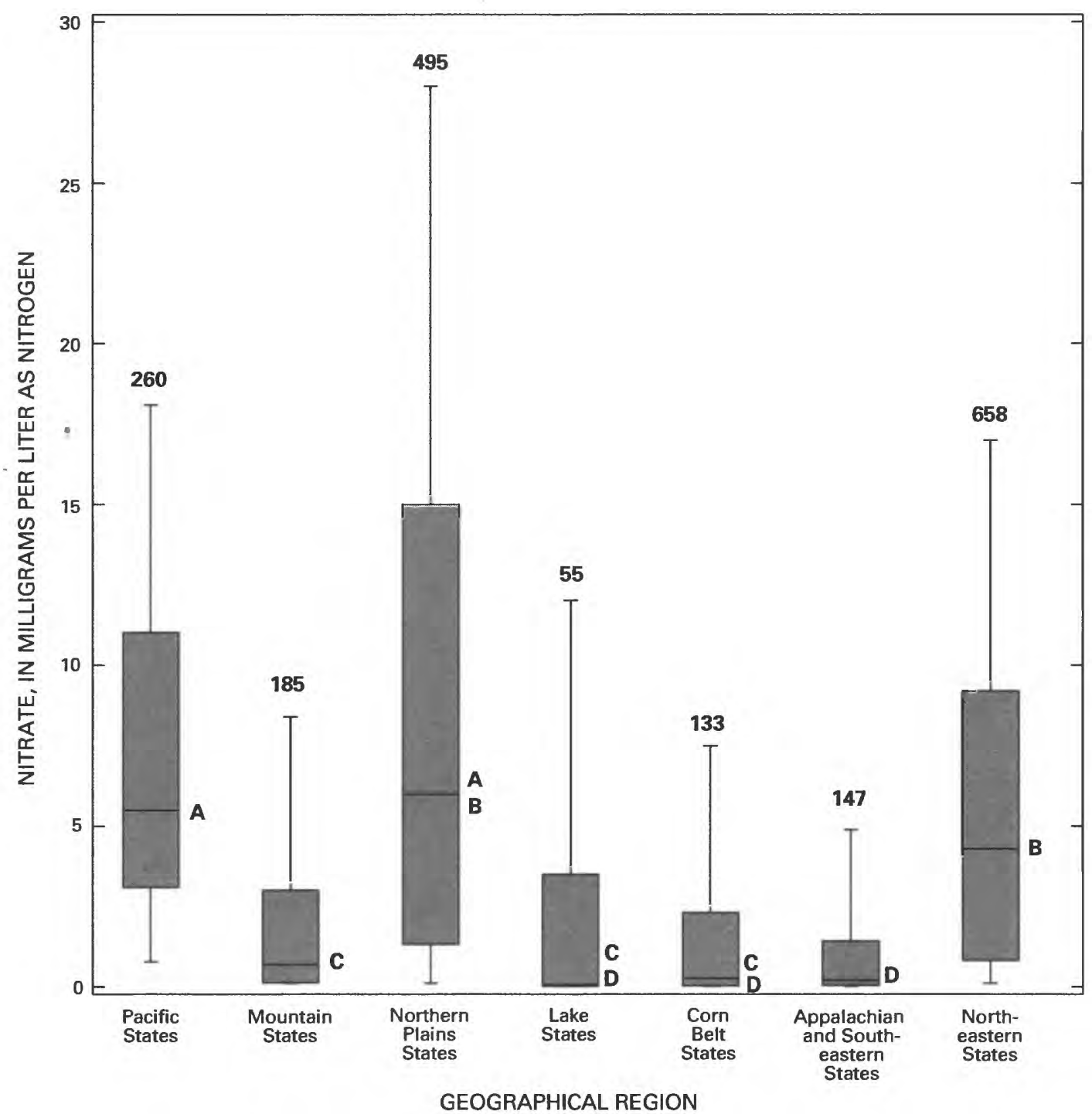

Figure 22. Nitrate concentrations in ground water beneath agricultural land by geographical regions of the United States for samples in the national retrospective data set. 

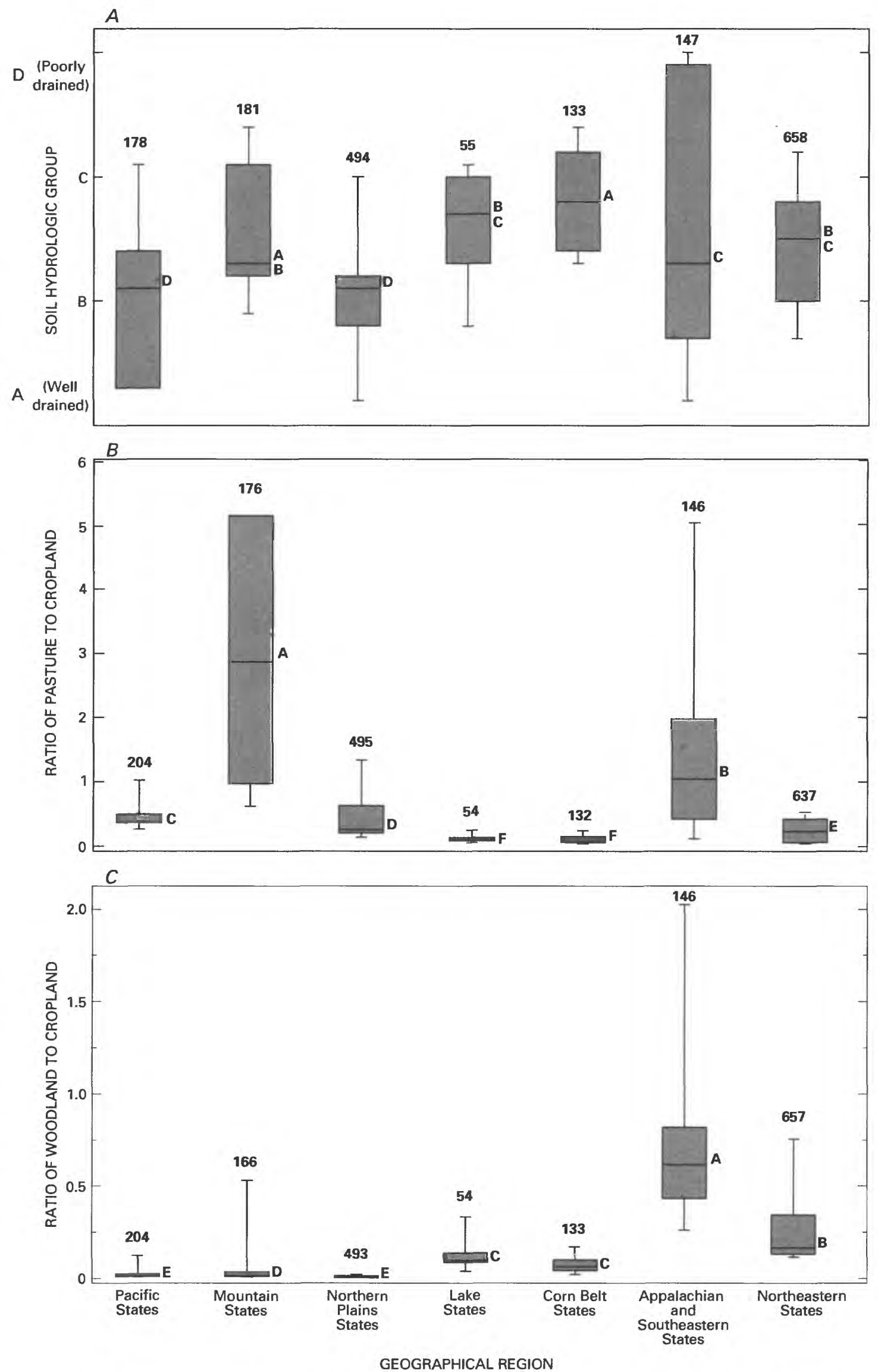

Figure 23. Distributions of (A) soil hydrologic groups, (B) ratios of pasture to cropland, and (C) ratios of woodland on farms to cropland in different geographical regions of the United States. 
Nitrate concentrations might be low, in part, because of denitrification in a warm, wet (average annual rainfall in the region is more than 50 inches), and carbon-rich environment (Spalding and Exner, 1993). Studies indicate areally extensive denitrification in poorly drained subsoils in parts of the Southeastern coastal plain, where substantial nitrogen fertilizer leaches below the root zone of agricultural areas but little nitrate reaches the ground water (Hallberg and Keeney, 1993, p. 300). In addition, nitrate concentrations in recharge water can be decreased because of vegetative uptake. Much of the land is forested near the Agricultural sites in the three study units in this region. The ratio of woodland to cropland is significantly higher than in any other region (fig. 23C). Hubbard and Sheridan (1989) reported that ground water in much of this region is protected by shallow retarding layers that perch the recharge and divert it laterally to swamps and other vegetated areas. Forested buffer strips between and within agricultural fields are common in the Apalachicola study unit and act as possible filters for nutrients (E.A. Frick, U.S. Geological Survey, written commun., 1994). Hamilton and others

(1993a) report low nitrate concentrations in agricultural areas of the Delmarva Peninsula that are highly interspersed with woodland. Potential causes of these low concentrations might include vegetative uptake, denitrification beneath riparian zones or wet wooded areas, and dilution of high-nitrate water that is recharged through the farmland with low-nitrate water recharged through adjacent woodlands.

\section{Corn Belt States}

The Corn Belt States have the largest proportion of cropland ( 58 percent) in the Nation (Spalding and Exner, 1993). Despite extensive fertilizer use (Kellogg and others, 1992, p. 21) and intensively cultivated land, nitrate concentrations in groundwater samples from this region were among the lowest in the national retrospective data set (fig. 22). The median concentration for the region was only $0.25 \mathrm{mg} / \mathrm{L}$, and only about 23 percent of the samples indicated effects of human activities (table 15).
Previous studies also have reported low concentrations of nitrate in ground water in the Corn Belt States. For example, Richards and others (1991) reported that nitrate concentrations in samples from only 2.7 percent of the 14,478 drinkingwater wells in Ohio exceeded the MCL. They found no relation between land use and ground-water nitrate concentrations in northwestern Ohio, where row-crop agriculture is most widespread. Counties with the most intense cultivation had some of the lowest average nitrate levels. In a survey of rural wells in Iowa, Kross and others (1990) reported that nitrate concentrations exceeded the MCL in only 5.6 percent of the wells in the intensively cultivated north-central part of the State.

One possible reason for low nitrate contamination in parts of the Corn Belt States is the composition of soils and surficial deposits. Soils at the sampling sites in this region were the most poorly drained of any region (fig. 23A). These soils contain significant amounts of loess or fine-grained glacial deposits that are relatively impermeable and that transmit water at a slower rate than more permeable sand and gravel. More than 60 percent of rural Illinois is underlain by thick sequences of fine-grained glacial deposits or low-permeability bedrock that protect the aquifers from contamination (McKenna and Keefer, 1991). Also, in many parts of northwestern Ohio, soils are deep and clay-rich, which provides a barrier to ground-water contamination (Richards and others, 1991).

Because of the low permeability of finetextured soils, tiling and ditching of farm fields to drain wet areas is a common agricultural practice in the Corn Belt States. Quantifiable data are unavailable for the acreage of tiled land in Indiana, but nearly all wet farmlands contain tiling systems (J.D. Martin, U.S. Geological Survey, written commun., 1994). In addition to providing drainage of excess water, tiling and ditching help maintain low nitrate concentrations in ground water. Nitrogen leachates from row-cropped land are intercepted by tile drains and ditches, and rather than moving downward to the water table, they are discharged to surface water (Spalding and Exner, 1993). According to Richards and others (1991), extensive use of tile drainage in Ohio diverts the nitratebearing water from the fields into surface drainage, preventing leaching to the ground water. Power 
and Schepers (1989) indicate that the diversion of nitrate-contaminated recharge by tile drains and its subsequent discharge to surface water is the major fate of surface-applied nitrogen in several States in the Corn Belt.

\section{Lake States}

Nitrate concentrations were generally low in ground-water samples collected in the Lake States (fig. 22). The median concentration of $0.06 \mathrm{mg} / \mathrm{L}$ was the lowest among all the regions; however, concentrations exceeded the MCL for nitrate in about 15 percent of the samples, which was greater than for several other regions, including the neighboring Corn Belt States. The median nitrate concentrations in samples from the Lake States and Corn Belt States were not significantly different (fig. 22).

As in parts of the Corn Belt States, one of the key factors controlling nitrate concentration in the Lake States is composition of soils and surficial deposits. Spalding and Exner (1993) reported that repeated glaciations in Michigan, Wisconsin, and Minnesota deposited various mixtures of soils. The data included in this analysis were collected at sites underlain by relatively poorly drained soils (fig. 23A) and, therefore, nitrate concentrations were generally low. Elevated concentrations were found in areas underlain by sandy soils, which are vulnerable to contamination from agriculture (Mossbarger and Yost, 1989; Spalding and Exner, 1991).

\section{Northern Plains and Pacific States}

Median nitrate concentrations in groundwater samples from the Northern Plains States and the Pacific States regions were not significantly different from one another but were significantly greater than medians from all other regions except the Northeastern States (fig. 22). Samples from these two regions also had the greatest percentage of concentrations in excess of the drinking-water MCL. Based on the 3-mg/L criterion, about 60-75 percent of the samples from these regions indicated effects of human activities.
The agricultural land in these regions is used intensively for row-crop farming. Soils are generally well drained and permeable (fig. 23A). Much of the land is underlain by unconsolidated material, such as sand and gravel, through which water and dissolved nitrate move readily downward to the water table. To maintain adequate conditions for crop growth, these areas have some of the highest rates of nitrogen-fertilizer application and irrigation in the Nation (Spalding and Exner, 1993). Use of inorganic fertilizer is particularly heavy in the Northern Plains and Pacific States (Kellogg and others, 1992). California has the largest amount of irrigated cropland in the Nation (about 17 percent of the national total; Solley and others, 1983, p. 18), and Nebraska has the second largest amount (Power and Schepers, 1989). The combination of permeable soils, high rates of fertilizer application, and irrigation provides a large source of nitrate and a high potential for nitrate transport to ground water. In addition, row crops commonly cover large tracts of land. The ratios of pasture to cropland are low in the Northern Plains and Pacific States (fig. 23B), and the ratios of woodland to cropland are significantly lower than in any other region (fig. $23 \mathrm{C}$ ). Thus, the potential is high that fertilizer applications and irrigation of row crops will cause high concentrations of nitrate through recharge to ground water.

\section{Mountain States}

The overall distribution of nitrate concentrations in ground-water samples collected from the Mountain States region was not significantly different from those of the Corn Belt and Lake States (fig. 22). However, concentrations were highly variable among the three study units within the region. Median concentrations ranged from $0.36 \mathrm{mg} / \mathrm{L}$ in the Rio Grande study unit to $2.9 \mathrm{mg} / \mathrm{L}$ in the Upper Snake study unit (table 15). The percentage of concentrations that indicated human activities or that exceeded the MCL also was highest in the Upper Snake study unit. Of the eight samples with more than $10 \mathrm{mg} / \mathrm{L}$ nitrate from the Rio Grande study unit, seven were from an intensively irrigated area in southern Colorado. 
Only 5 percent of the Mountain States region is cultivated; more than one-half of the land is used for rangeland and pasture and about one-fourth is forested (U.S. Department of Agriculture, 1988). Low concentrations of nitrate, such as observed in the Nevada study unit and most of the Rio Grande study unit, are typical of much of the region because of the extensive acreage used for pasture and grazing. The ratio of pasture to cropland is significantly larger at sites in the Mountain States than at sites in any other region (fig. 23B). Accordingly, sources of nitrogen are generally low in this region. Elevated concentrations in the Upper Snake study unit and the Colorado part of the Rio Grande study unit are consistent with the conclusions of Spalding and Exner (1993) that areas of the Mountain States with nitrate-contaminated ground water are associated with large feedlots and irrigated fields in Montana, Idaho, Colorado, and Arizona.

\section{Trends in Nitrate Concentrations in Ground Water}

Little information exists about trends in the quality of ground water; only recently have monitoring programs begun to sample ground-water quality at the same locations over time. Some information on trends in nitrate concentrations was available at a few locations in several NAWQA study units, but no information on trends in ammonia, organic nitrogen, or phosphorus concentrations in ground water was found. Clearly, additional information on trends in groundwater quality is needed across the Nation.

The largest amount of information available on trends in ground water was from the Georgia-Florida study unit (Berndt, in press). Wells less than 100 feet in depth tapping the unconfined part of the Upper Floridan aquifer in central Florida were sampled from about 1972 through 1990. Three land-use settings were represented: Agricultural Land, Forest Land, and Urban Land. Data from six wells in Agricultural areas are shown in figure 24. In samples from each of these wells, a Mann-Kendall trend test determined that nitrate concentrations increased significantly over the time period. Concentrations were generally low, all less than $3 \mathrm{mg} / \mathrm{L}$, in agreement with other general results for the Southeastern States. Most wells showed continual, gradual increases in nitrate concentrations, although one well showed a sharp increase during 1984 86. In contrast, no trends in nitrate concentration were identified in three wells located in nearby forested areas, and an insignificant $(\mathrm{p}=0.08)$ increase was noticed at the one well located adjacent to a recent residential development. In addition, nitrate concentrations increased in one of two wells in Urban Land-use areas. These data indicate that increasing trends in nitrate concentration might be more common in ground water beneath agricultural areas than beneath other land uses of the Southeast.

Exner and Spalding (1990) reported that nitrate increased between 1974 and 1984 in samples from numerous wells over a multi-county area of intense agricultural activity in the Platte River Valley, within the Central Nebraska study unit (fig. 25). The largest increases occurred in shallow ground water, with concentrations commonly greater than the drinking-water MCL in the 1984 samples.

Eight wells in the Upper Snake study unit had sufficient data for trend analysis. The four sites from irrigated agricultural areas are shown in figure 26. All four wells showed some increase in concentration since 1980. More data are needed before the trends evident in these locations can be considered typical of ground water under irrigated agriculture in the study unit.

In the Central Columbia study unit, several agricultural wells showed increasing nitrate trends since the 1950's. Use of irrigation and fertilizer has risen substantially over that time period. Some nearby wells did not show an increase, which was attributed to hydrologic conditions (lack of fracturing, presence of overlying clay layers) that retarded transport of surficial nitrate to the subsurface.

Less information exists on trends in wells outside of agricultural areas. In the Connecticut study unit, elevated nitrate concentrations were observed in the 1950's and 1960's in wells tapping the shallow parts of stratified-drift aquifers (M.J. Zimmerman, U.S. Geological Survey, written commun., 1994). These incidents were attributed to surface contamination. The most urbanized drainage basin had the highest frequency of wells exceeding $2.2 \mathrm{mg} / \mathrm{L}$, Connecticut's threshold for background nitrate concentrations. More long-term information is needed to evaluate the effects on ground water of fertilizer applications to urban areas such as lawns, parks, and golf courses. Information is also lacking on ground-water quality of undeveloped areas. Only one study unit had this information; measurements over 10 years at five springs in forested areas of the Ozark study unit showed no significant change in nitrate concentrations. 

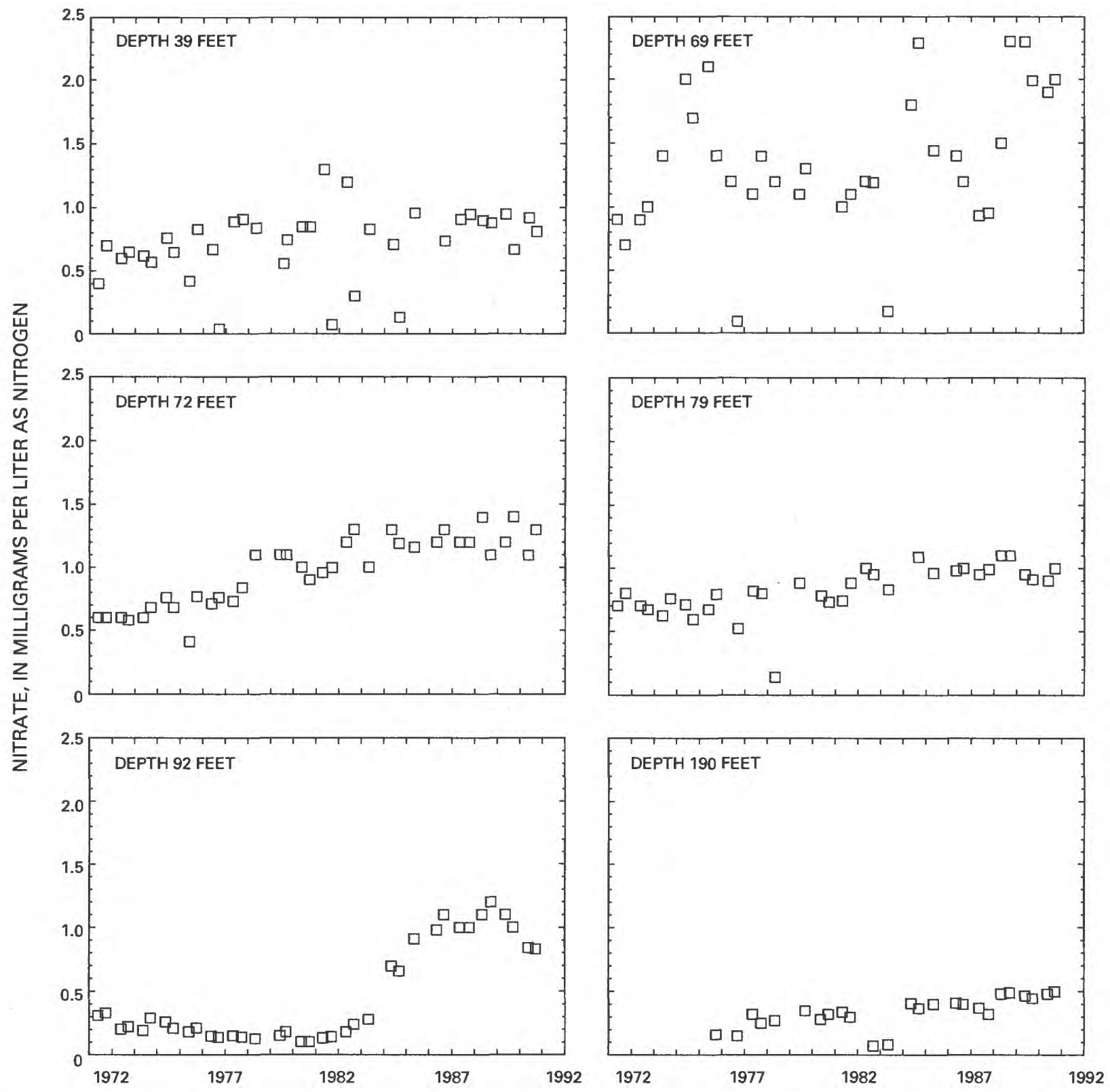

Figure 24. Trends of nitrate concentrations in ground water from the unconfined Upper Floridan aquifer in agricultural areas in the Georgia-Florida Coastal Plain study unit (from Berndt, in press). 


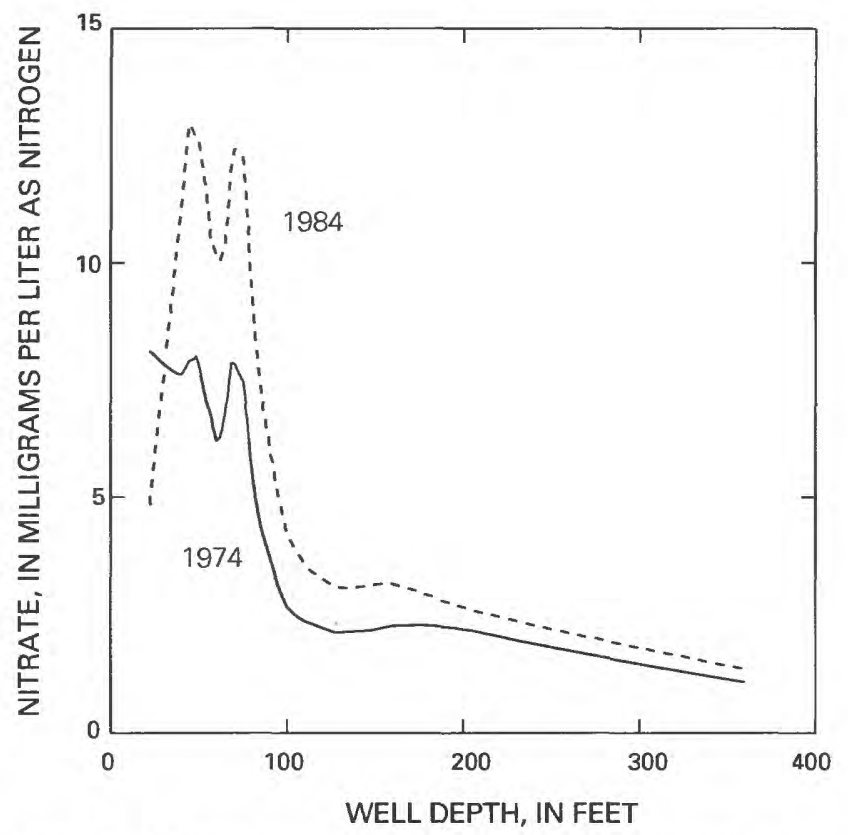

Figure 25. Nitrate concentrations in ground water in the central Platte River Valley, Nebraska, during 1974 and 1984 (data from Exner and Spalding, 1976; Exner, 1985).
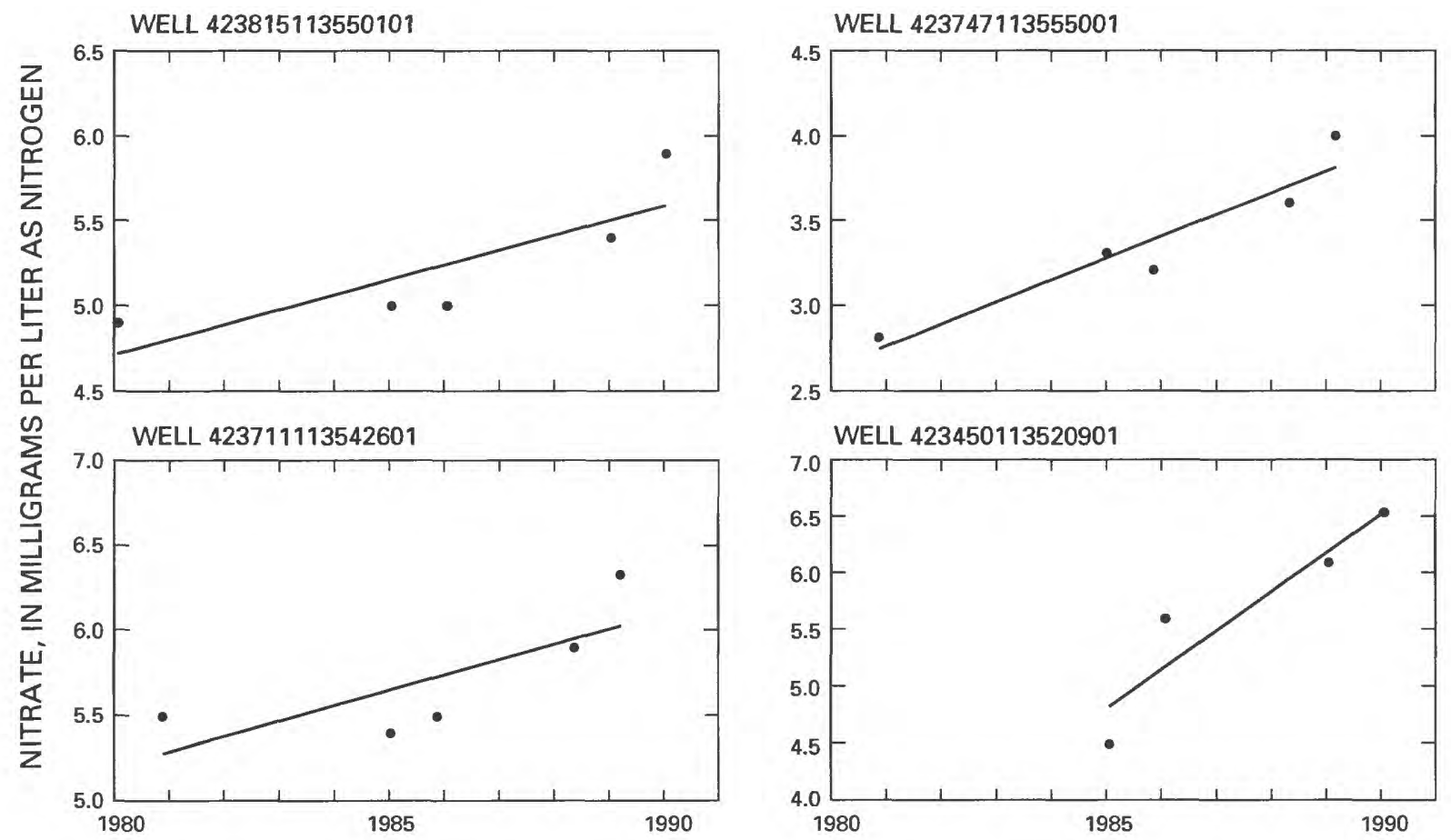

Figure 26. Trends of nitrate concentration in ground water from selected wells in the Upper Snake River Basin study unit (modified from Rupert, 1994). 


\section{NUTRIENTS IN SURFACE WATER OF THE UNITED STATES}

Nutrients in surface waters have been a concern for several decades. The earliest public interest was in lake and reservoir eutrophication resulting from excessive nutrient inputs. Algae feeding on these nutrients grew into unsightly scum on the water surface, decreasing the waters' recreational value. Death and decay of algae lowered oxygen levels, occasionally resulting in fishkills. Beginning in the 1970's, the most widespread concern focused on the amount of ammonia discharged to streams from wastewater-treatment plants. Ammonia removes dissolved oxygen from water to form nitrate. When the amount of effluent and the ammonia content was sufficient, oxygen concentrations dipped below those necessary to support life, and fishkills became common. Effluent phosphorus concentrations also were blamed for continuing eutrophication of slow-moving waters. The Water Pollution Control Act of 1972, later known as the Clean Water Act, mandated improvements in wastewater-treatment technology, to be funded jointly by the States and Federal and local governments. From 1972 to 1990 , between 11.8 and 15.3 billion dollars per year were spent on capital improvements to upgrade wastewater-treatment facilities of the United States (U.S. Environmental Protection Agency, 1990d). While those costs are expected to decline in the 1990's, the costs of operating these point-source facilities and complying with existing regulations are expected to reach 19 to 20 billion dollars per year (U.S. Environmental Protection Agency, 1990d). Fur- ther upgrades to advanced wastewater treatment will be even more expensive, with less and less additional nutrients removed. The potential for additional nutrient removal from point-source effluents may be small in comparison to the large amount of nutrients in nonpointsource runoff from a variety of activities on the land surface.

Nonpoint sources of nutrients have increased dramatically since World War II. Between 1945 and 1985, commercial nitrogen fertilizer use increased twentyfold in the United States (fig. 27). Puckett (1994) compared the amount of nitrogen and phosphorus currently being applied to the land surface in commercial fertilizers, animal manure, and atmospheric deposition to the amount entering nearby streams from point sources. From 1978 through 1981, point sources discharged about 1.3 million tons-of nitrogen per year directly into streams, while nonpoint-source applications aecounted for 21.4 million tons of nitrogen per year. Point sources affect stream quality downstream from cities and towns, but nonpoint sources produce the dominant effect on most of the river miles in the Nation. In the Northeast, atmospheric deposition is an important source of nitrogen to watersheds; numerous wooded areas remain, and agriculture is less intensive than in the Midwest and West (Puckett, 1994). In the Southeast, animal manure is the single largest source for nitrogen, whereas commercial fertilizers are the predominant sources of nitrogen in the Midwest and West. Within these general regional patterns, Puckett found that accounting for sources of nitrogen within specific watersheds must take local factors into consideration.

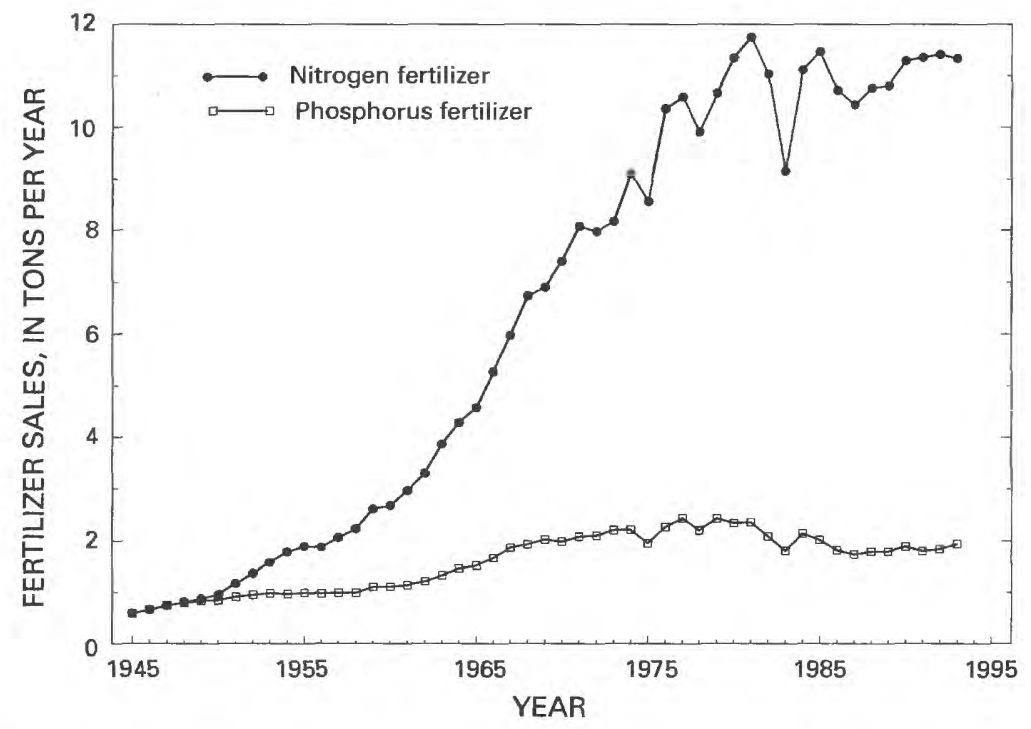

Figure 27. Trends in annual sales of nitrogen and phosphorus fertilizer sales in the United States (data from Alexander and Smith, 1990). 
Most surface-water nutrient studies have been done on a river-basin or smaller areal scale. Some of these studies were intended to evaluate the relation of nutrient runoff to various land uses or to determine the effects of various land-use practices (for example, Bormann and others, 1968; Dierberg, 1991; Stottlemyer and Troendle, 1992; and Fishel and others, 1993). Other studies were intended to determine nutrient inputs to lakes, reservoirs, bays, or estuaries (for example, Edmondson and Lehman, 1981; Rosensteel and Strom, 1991; Hager and Schemel, 1992; and Jaworski and others, 1992). These types of studies have had varied purposes, and data have been collected on different nutrient species over different time periods; therefore, they are not suitable for a national summary.

Few nationwide inventories of nutrients in surface water have been made. The USEPA National Eutrophication Survey was primarily an effort to collect data on lakes and their watersheds. Omernik (1977) used those data in a national study of nonpoint-source nutrient runoff. He related nutrient concentrations in streams to land use, reporting that total nitrogen and total phosphorus concentrations were nearly nine times greater downstream from agricultural lands than downstream from forested areas. He also noted several regional patterns. Phosphorus concentrations downstream from forested watersheds were higher in the Western United States than they were in the East. Conversely, inorganic nitrogen concentrations downstream from forested areas were higher in the Eastern United States. Nitrogen concentrations downstream from agricultural areas were highest in the Corn Belt States. The Nationwide Urban Runoff Program, which was a joint project of the USEPA and the USGS, was an effort to collect and interpret data on nonpoint-source runoff in urban areas. Results indicated that nutrients were generally present in urban runoff, but concentrations were not high in comparison to other possible discharges to receiving waters (U.S. Environmental Protection Agency, 1983).

Smith and others (1987) investigated trends in nitrate and total phosphorus for the period $1974-81$ at 380 sites, primarily on major rivers with large upstream drainage areas that were sampled as part of the USGS National Stream Quality Accounting Network (NASQAN) and National Water Quality Surveillance System. Increases in nitrate were widespread and were attributed to increasing trends in fertilizer use. Total phosphorus concentrations declined in much of the Great Lakes area and Mississippi River Basin but were constant elsewhere. The declines were attributed to improvements in wastewater-treatment practices. In a subsequent study, Smith and others (1993) found far fewer trends in nitrate at 344 sites for the period 1980-89. They believed that this change was due in part to the leveling off of nitrogen fertilizer use in the United States during the 1980's. Total phosphorus concentrations declined at most of the 420 sites across the Nation for 1982-89. This they attributed to decreases in the phosphorus content of detergents, improved wastewater treatment, and decreases in phosphorus applied as fertilizer. Smith and others (1993) also determined that nutrient yields (tons delivered per square mile per year) for streams were quite different among areas of different land use. Nitrogen yields were twice as high in streams draining corn and soybean agriculture than in urban streams, while total phosphorus yields were 33 percent higher. Streams draining forest, rangeland, or wheat agriculture had much lower yields for both nutrients.

\section{Factors Affecting Nutrient Concentrations in Surface Water}

Personnel from each of the 20 NAWQA study units evaluated the factors affecting surface-water quality in their areas. Their findings are reported in a series of retrospective reports (see table 1). Striking similarities among the study units were found. The effects of land use on water quality and the effects of improved wastewater treatment on trends in streamwater quality in urban areas were notably similar. Results consistent among several study units are summarized below. Following that, analyses of the national retrospective data set, compiled from all 20 study units, are presented to give a national summary of patterns in surface-water quality.

\section{Drainage from Different Land Uses}

Consistent differences were found among many of the NAWQA study units in the quality of surface water draining different land-use settings. Generally, nutrient concentrations were higher downstream from agricultural areas than downstream from undeveloped land (fig. 28). For example, in the San Joaquin study unit, concentrations of nitrate, total nitrogen, total phosphorus, and sediment were highest in areas receiving agricultural drainage. Nitrate concentrations regularly exceeded $10 \mathrm{mg} / \mathrm{L}$ in drainage waters. An abundance of vegetables and other specialty crops are produced in this study unit, and fertilizer is heavily applied. In the lower San Joaquin River, nutrient concentrations increased as more agricultural drainage entered the river from tributaries and drains. 


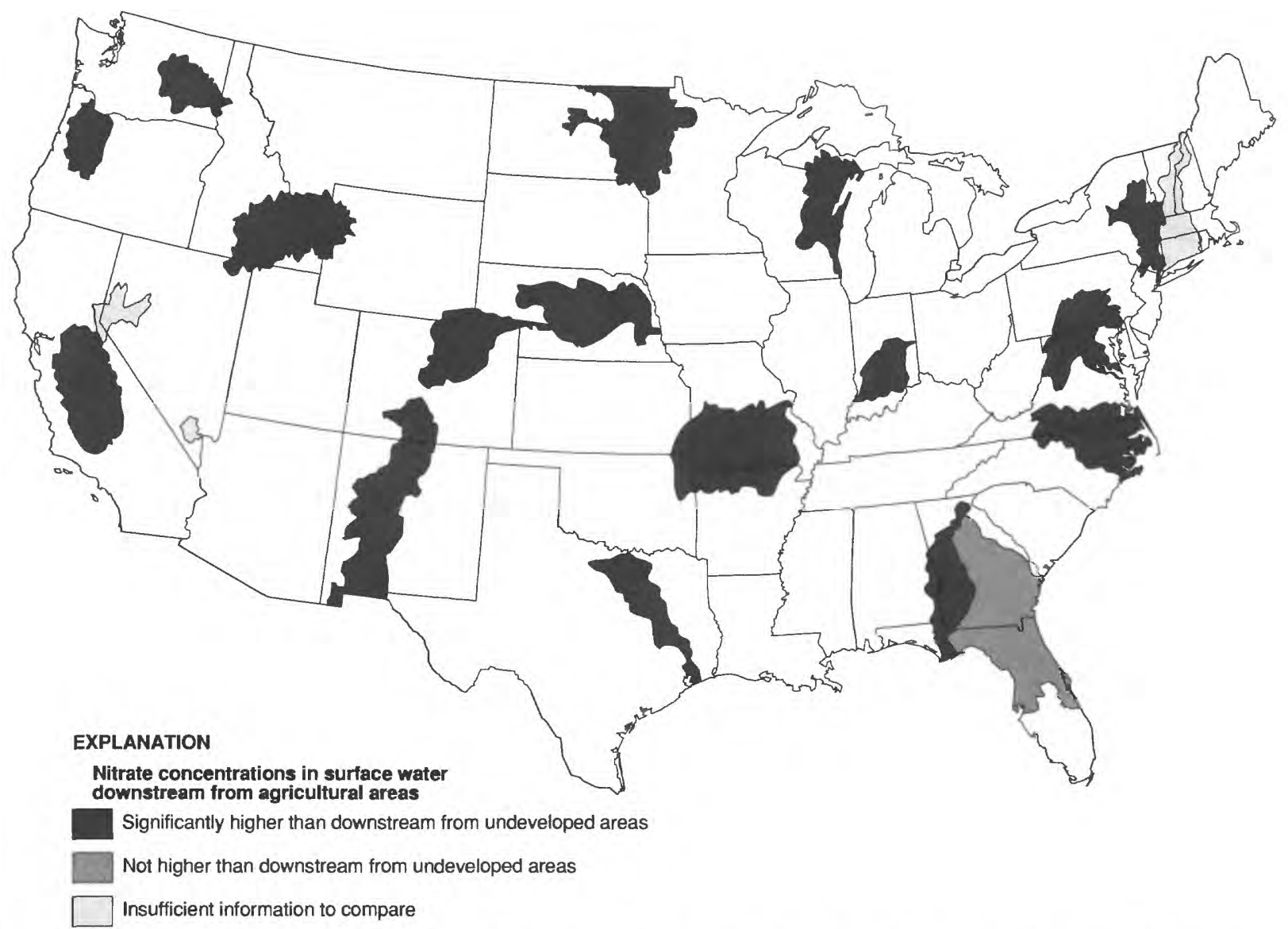

Figure 28. NAWQA study units where nitrate concentrations in surface water were significantly higher downstream from agricultural areas than from undeveloped areas (refer to figure 1 for study-unit identification). 
In the Red study unit, wheat and other grains are the dominant crops. Although fertilizers are applied in quite different amounts than in California, nutrient concentrations were again higher in agricultural areas than downstream from undeveloped land. Nitrate concentrations were greater than $1 \mathrm{mg} / \mathrm{L}$ in some agricultural areas, an elevated amount for this study unit. Total Kjeldahl nitrogen was also highest downstream from agricultural areas.

In the Central Nebraska study unit, the highest nitrate concentrations occurred in streams draining cropland. Nitrate, total nitrogen, orthophosphate, and total phosphorus were also highest in streams draining agricultural areas of the Upper Snake study unit. Median concentrations of $1.4 \mathrm{mg} / \mathrm{L}$ were an order of magnitude higher than, and significantly different from, streams draining nonagricultural areas or main-stem locations with mixed land-use influences. In the South Platte study unit, nitrate concentrations were highest in agricultural-area streams, and other nutrients were highest in either Agricultural or mixed Agricultural/Urban locations (fig. 29). In the Trinity and Lower Susquehanna study units, nitrate concentrations increased with increasing percentages of Agricultural Land upstream. The strength of these relations was limited by the quality of the land-use data available. Cropland and pasture were lumped together as "Agricultural," even though the amount of fertilizer applied on those land types differed substantially.

Streams draining lands where animals are raised or where animal manure is heavily applied also contained high nutrient concentrations. In the Ozark study unit, sites downstream from pastures had elevated nitrate and phosphorus concentrations in comparison to sites downstream from Forest Lands. In contrast, ammonia concentrations were higher downstream from cropped areas than in streams draining pastures. Again, the lack of accurate land-use data limited interpretations, as there was no information on the amount of manure spread on cropped lands. In the Potomac study unit, the nitrogen removed from the land surface to streams was much greater in areas where nitrogen fertilizer or manure was applied than in forested areas.

\section{Variations in Streamflow}

Nutrient concentrations change as streamflow changes. The way in which concentrations change is a reliable indicator of the types of nutrient inputs upstream. Point and nonpoint sources have characteristically different patterns as streamflow changes. These patterns can aid in identifying the types of upstream sources of nutrients affecting a given monitoring site. Nitrate concentrations generally change very little as streamflow changes at sites downstream from Undeveloped Land. For example, in samples from three forested sites in the Ozark study unit, nitrate concentrations remained quite low (less than $0.8 \mathrm{mg} / \mathrm{L}$ at the maximum), with only small increases as flow increased (fig. 30). No dilution was indicated as flow increased.

Orthophosphate concentrations decreased with increasing streamflow in the Rio Grande downstream from a wastewater-treatment plant (fig. 31). Such decreases are typical for nutrients at sites affected by point sources. Concentrations are added at a relatively constant rate, dominating the river's chemistry at low streamflow. Cleaner waters from upstream dilute the high-concentration effluents at larger streamflows. Sharp decreases in nutrient concentrations with streamflow are usually indicative of point-source-dominated river reaches. However, nonpoint sources can produce a similar pattern (fig. 32). Agricultural return flows high in nutrients constitute most of the flow of the San Joaquin River near Newman, California, at low streamflows. At higher streamflows, cleaner water is delivered from the eastern side of the San Joaquin Valley by the Merced River, and concentrations in the San Joaquin River decrease. Nonpoint sources will produce this pattern only when they dominate the chemistry of ground-water and soil-water inputs at low flow.

An agricultural site in the Willamette study unit illustrates how dissolved nutrients such as nitrate typically change with streamflow (fig. 33A). Nitrate is flushed out of soils, and concentrations continually increase as flow increases. Similar examples could be taken from a variety of streams across the Midwestern and Eastern United States. Exceptions like that described previously for the San Joaquin, where nonpoint sources dominate low-flow chemistry, occur most often in arid lands or in carbonate terrains.

Phosphorus from nonpoint sources follows a different pattern because it is transported attached to sediment particles rather than dissolved in water (fig. 33B). Sediment and phosphorus concentrations follow a U-shaped pattern as streamflow increases. Concentrations initially decrease due to dilution because flow is insufficient to add sediment to the stream. As flows increase further, phosphorus concentrations substantially increase as sediment is washed into the stream. The U-shaped pattern for sedimentrelated phosphorus and the continual increase for dissolved nutrients together are characteristic of nonpointsource-dominated stream reaches. 

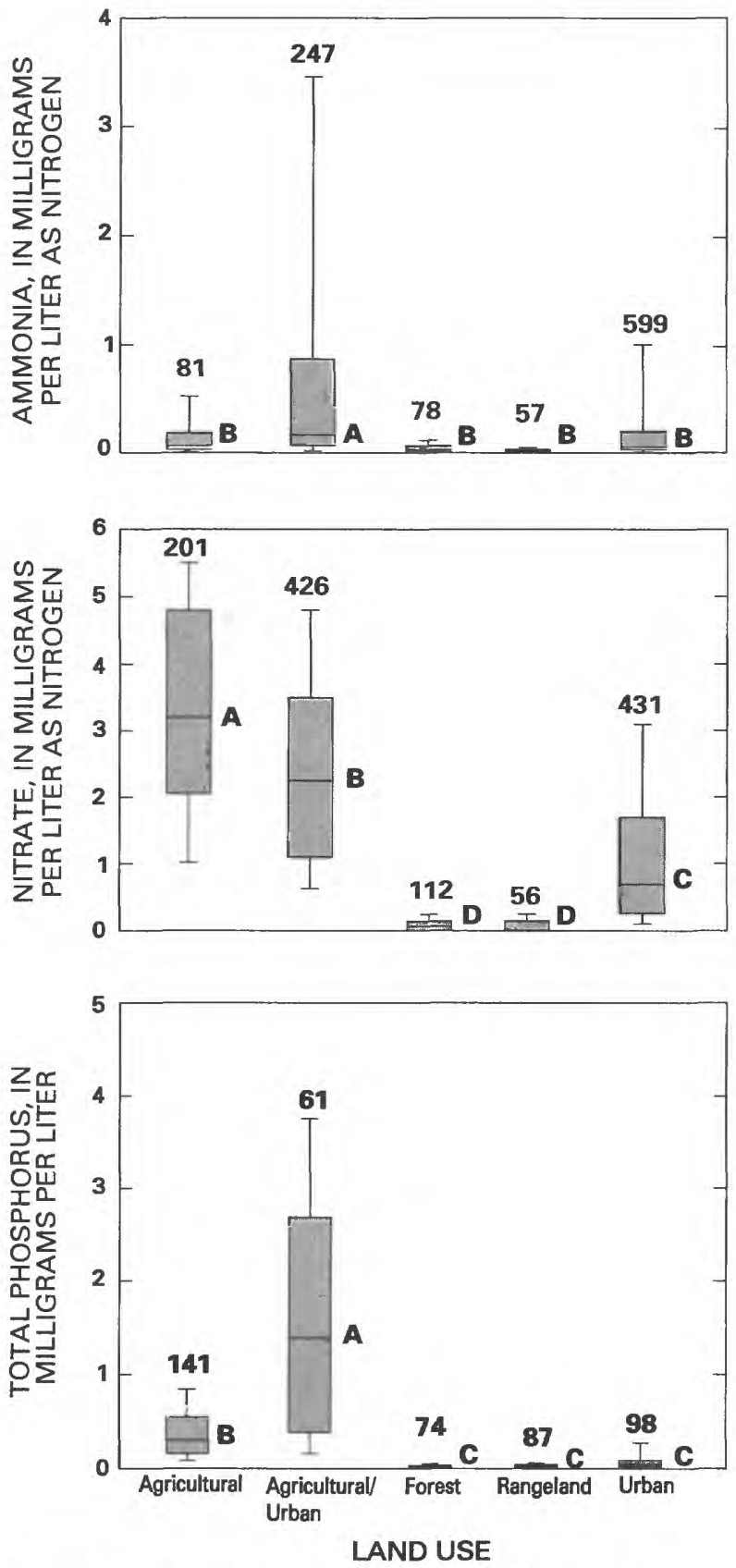

Figure 29. Concentrations of selected nutrients at surface-water sites in the South Platte River Basin study unit categorized by upstream land use (modified from Dennehy and others, 1994). 


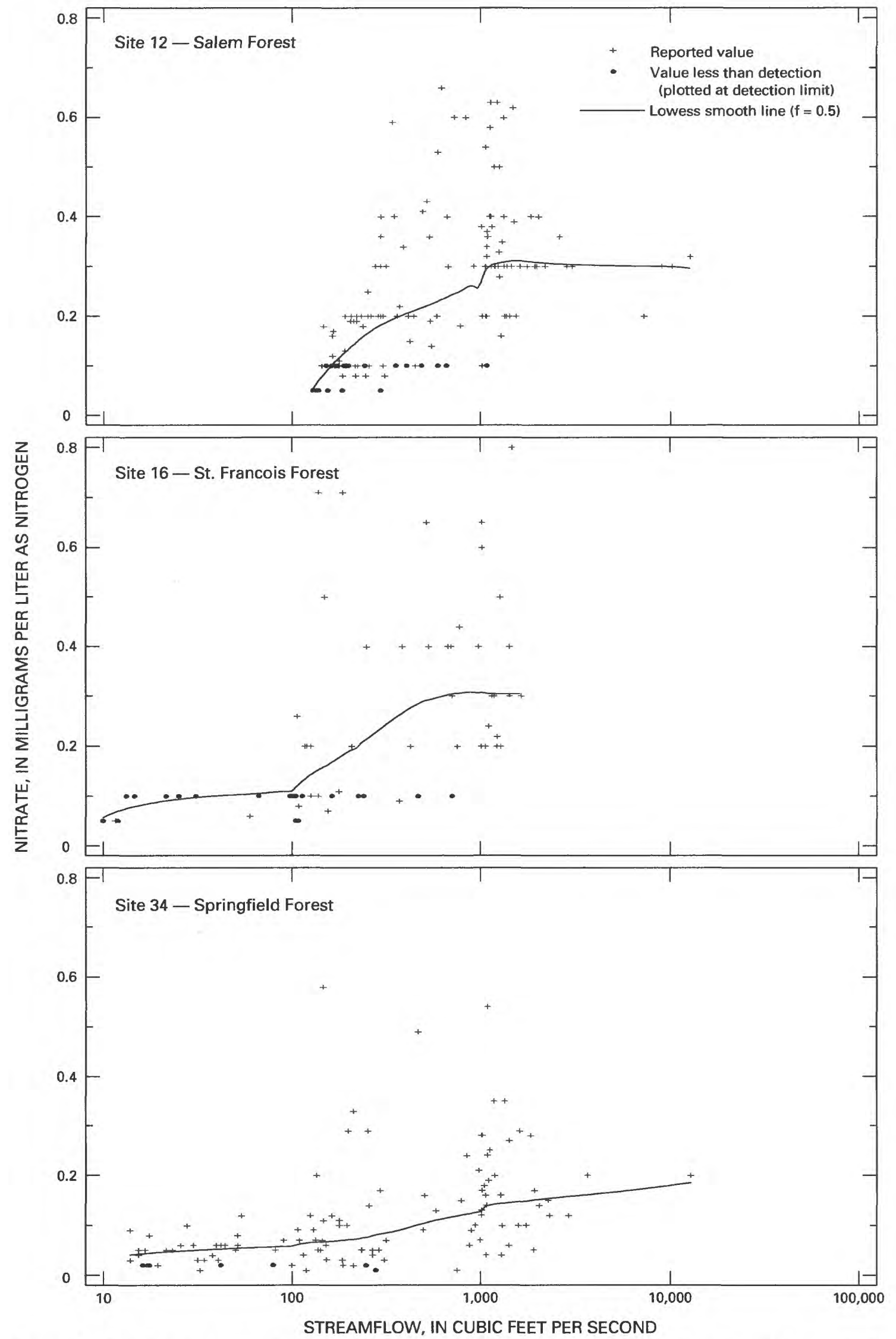

Figure 30. Relations between nitrate concentrations and streamflow downstream from forested areas in the Ozark Plateaus study unit (from Davis and others, in press). 


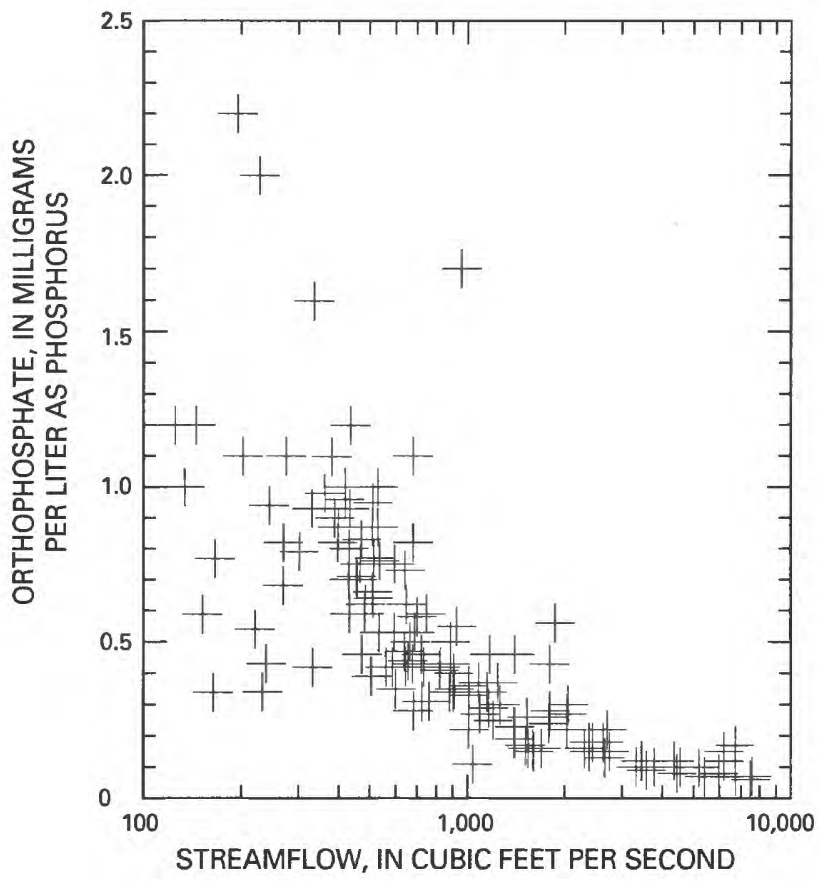

Figure 31. Relation between orthophosphate concentration and streamflow downstream from a wastewater-treatment plant in the Rio Grande Valley study unit (modified from Anderholm and others, 1994).

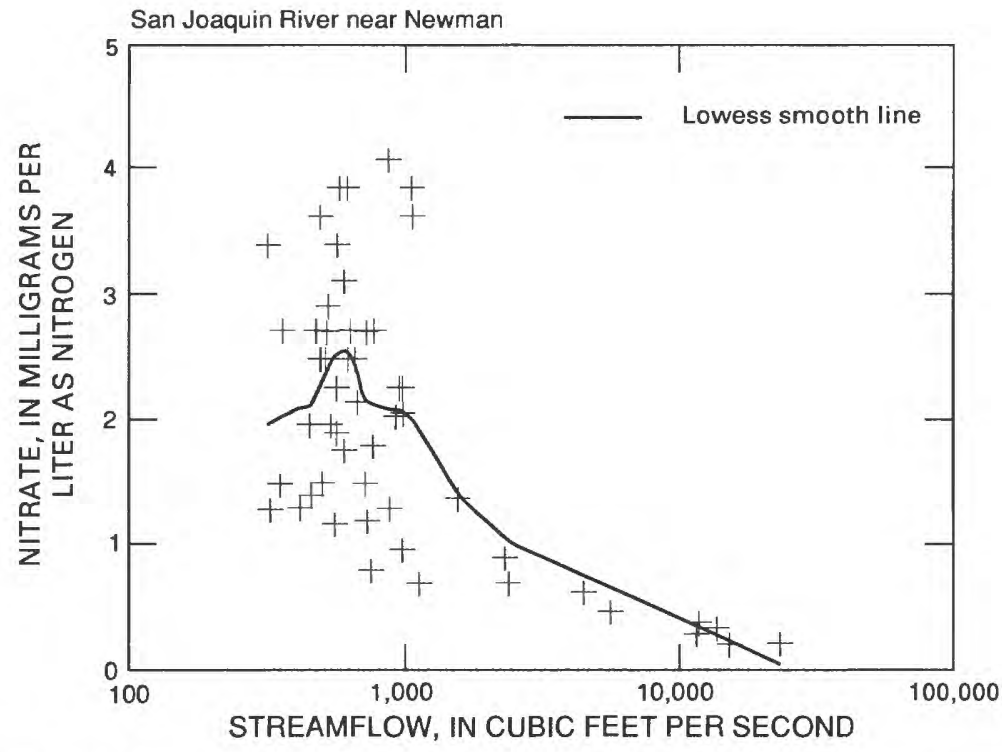

Figure 32. Relation between nitrate concentration and streamflow downstream from agricultural return flows in the San Joaquin-Tulare Basins study unit (from C.R. Kratzer, U.S. Geological Survey, written commun., 1994). 

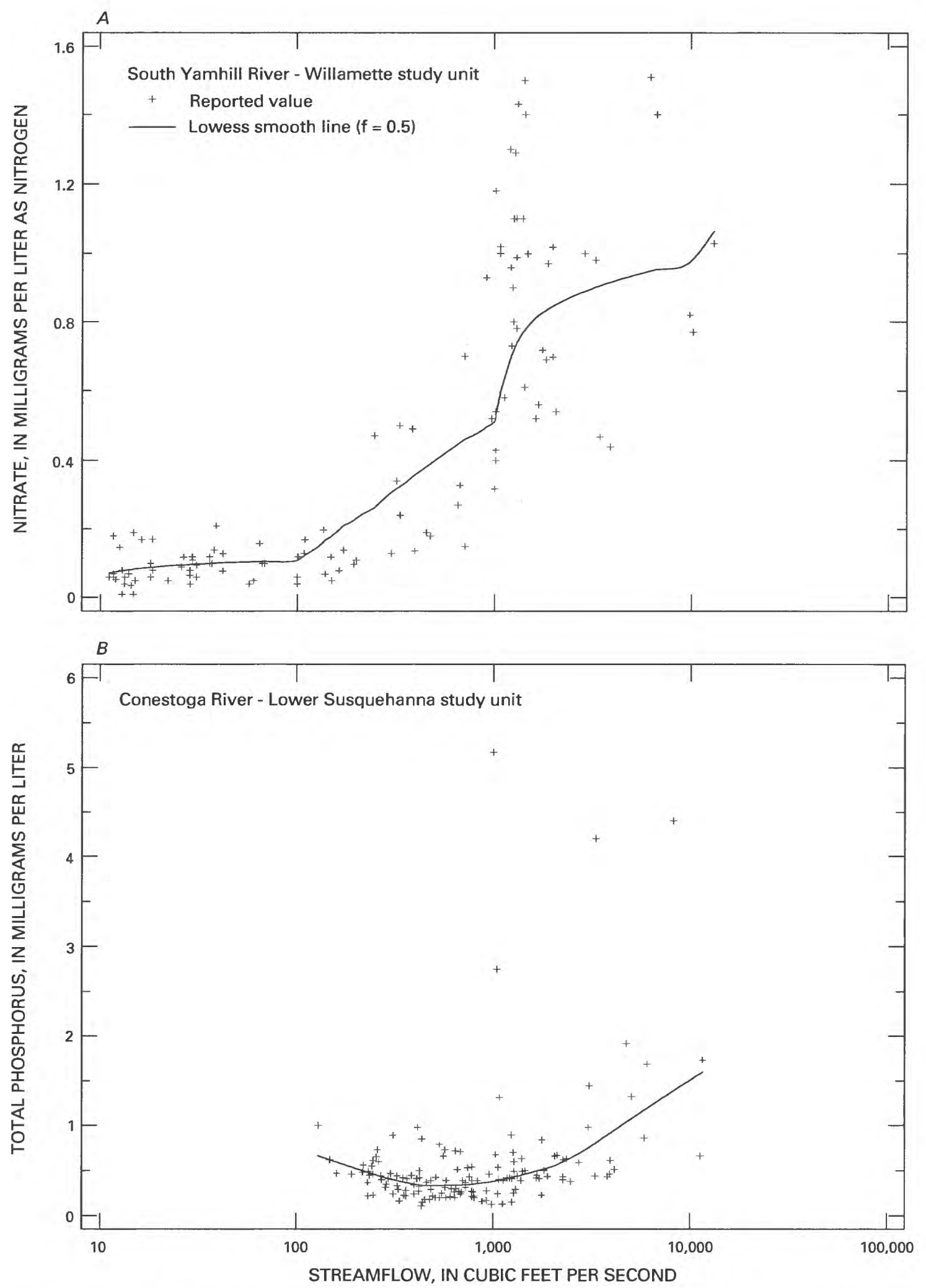

Figure 33. Relations between nutrient concentrations and streamflow downstream from agricultural areas in (A) the Willamette Basin study unit (from Bonn and others, in press), and (B) the Lower Susquehanna River Basin study unit (from R.A. Hainly, U.S. Geological Survey, written commun., 1994). 
Improved Wastewater Treatment

In urban areas within 10 of the 20 NAWQA study units, the proportion of nitrogen occurring as ammonia has decreased, and the proportion as nitrate has increased, in streams downstream from wastewater-treatment plants (fig. 34). For example, nitrate constituted a much larger percentage of nitrogen transported by the Trinity River during 1987-91 than it did during 1974-76 (fig. 35). At the same time, ammonia concentrations decreased. Several fishkills in the 1970's were caused by ammonia releases in effluent from the Dallas-Fort Worth area. To correct this problem, the wastewater-treatment process was upgraded in the late 1970's to convert ammonia into nitrate. As a result, nutrient releases to surface waters no longer pose a concern for fish toxicity but might be a concern for eutrophication. The total amount of nitrogen potentially available to algae and other organisms downstream is not necessarily decreased by improved wastewater treatment. Similar shifts from ammonia to nitrate occurred in the White River near Indianapolis, the South Platte River near Denver, the Chattahoochee River near Atlanta, and at several locations in the urbanized environs of the Connecticut study unit. This pattern appears to be widespread in urban areas throughout the Nation.

A second trend identified at urban locations was decreases in phosphorus concentration or load following mandated controls on phosphorus in wastewatertreatment-plant effluents. These decreases were caused by limits on the phosphate content of detergent, which were established to reduce the amount of phosphorus input to treatment plants, and additional treatment, in some plants, to remove phosphorus. The Potomac River, Chattahoochee River, Connecticut River, and several sites in urban areas of the W. Lake Michigan study unit all showed decreases in phosphorus concentrations during the 1980's that were attributed to decreased phosphorus loads in treatment-plant effluent. The load of phosphorus and the amount of effluent discharged by six wastewater-treatment plants in the Atlanta metropolitan area are shown in figure 36A (Wangsness and others, 1994). Although the amount of effluent discharged by the plants increased after 1989 , the year when phosphate restrictions began, the load of phosphorus decreased by 83 percent between 1989 and 1993. The effect on the Chattahoochee River is shown in figure $36 \mathrm{~B}$, where in-stream loads are plotted over time at sites upstream and downstream from Atlanta. There has been about a 54-percent decrease in the amount of phosphorus carried by the river downstream from Atlanta following the reduction of phosphorus in wastewater-treatment-plant effluent.

\section{Atmospheric Inputs}

The most prevalent trends in nutrient concentrations over time were the previously discussed increases in nitrate and decreases in ammonia near urban areas because of changes in wastewater-treatment-plant technology. However, other less widespread trends were identified in several NAWQA study units. Some of the longest records were for sites downstream from forested areas in the Hudson study unit (fig. 37), where nitrate concentrations have increased over time, especially after 1970 (Murdoch and Stoddard, 1992). Concentrations in these wooded areas have increased from below $0.2 \mathrm{mg} / \mathrm{L}$ to a median of around $0.4 \mathrm{mg} / \mathrm{L}$, without any immediate sources to the stream other than the atmosphere (P.J. Phillips, U.S. Geological Survey, written commun., 1994). These increases are consistent with increased atmospheric sources of nitrogen in the Northeastern United States.

\section{Changes in Farm Practices}

Most long-term data collection suitable for trend analysis of stream-water quality have occurred at sites integrating large areas; therefore, associating trends with changes in specific agricultural practices is difficult. However, a few NAWQA study units found evidence of changing water quality at sites in agricultural areas. The longest record was in the San Joaquin study unit, where fertilizer applications have doubled since the 1950's. The use of tile drains to remove water from fields and deliver it to nearby streams has also greatly increased during this time. Increasing nitrate concentrations in the lower San Joaquin River since the 1950's can be attributed to these increased agricultural activities within the drainage basin (C.R. Kratzer, U.S. Geological Survey, written commun., 1994).

One agricultural site in the Upper Snake study unit exhibited a downward trend in phosphorus. Upstream from this site were agricultural areas where bestmanagement practices had been implemented during the 1980's (Clark, 1994). The decrease in phosphorus at this site was attributed to a decrease in sediment reaching the stream after these practices were implemented. Evaluation of trends at other sites due to improved farming practices would require data records preceding implementation, and those rarely are available.

Many stations on streams draining agricultural areas showed no trends in nutrients during the 1980's. This is not surprising, as fertilizer use was generally unchanged during the decade after peaking around 1981 (Alexander and Smith, 1990). Smith and others (1993) noted that trends in nitrate at large sites draining agricultural areas across the Nation were far fewer than they had been in the late 1970's, and attributed this to the decade's plateau in fertilizer use. 


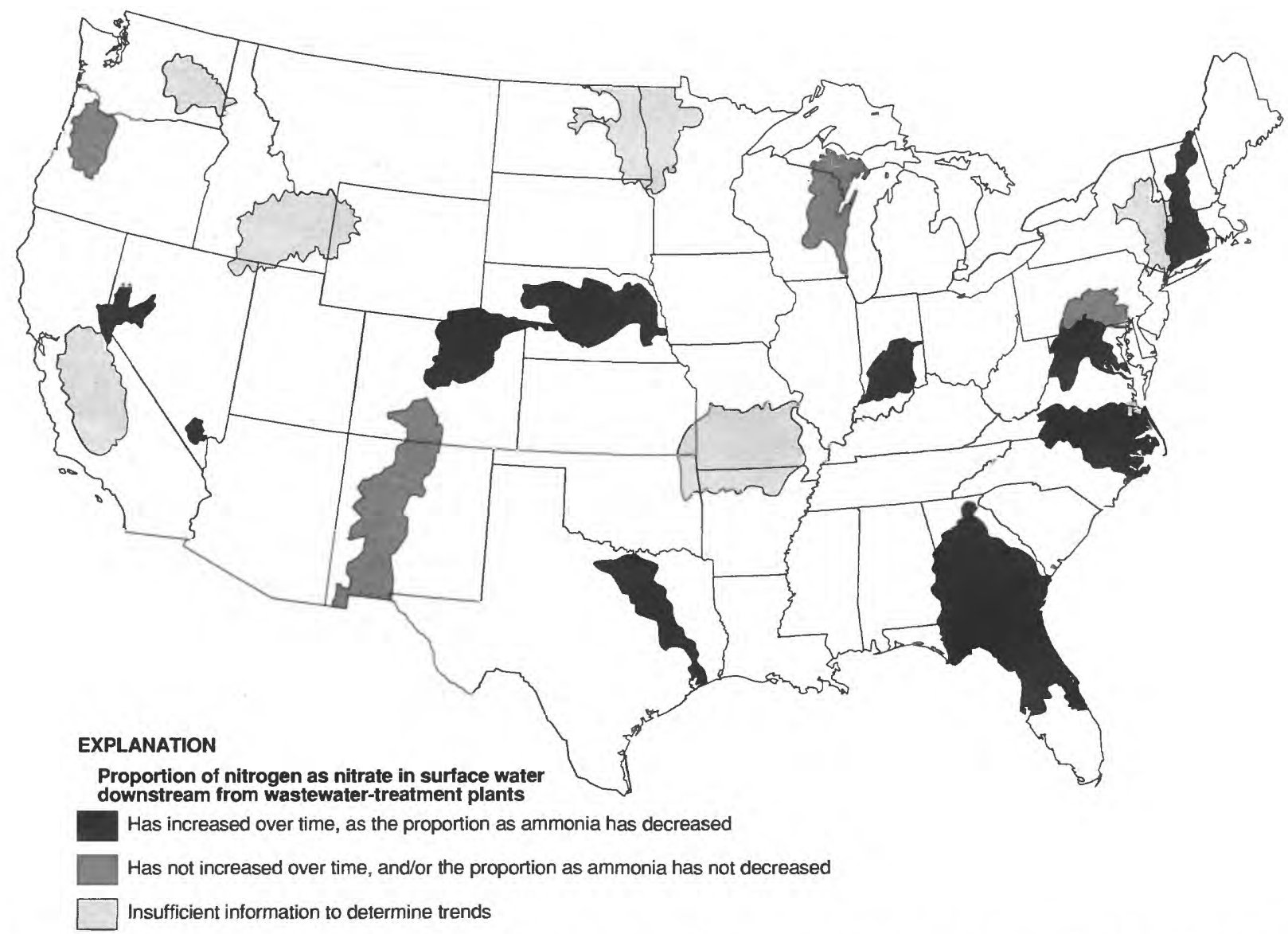

Figure 34. NAWQA study units where ammonia concentrations decreased and nitrate concentrations increased in surface water downstream from wastewater-treatment plants. 


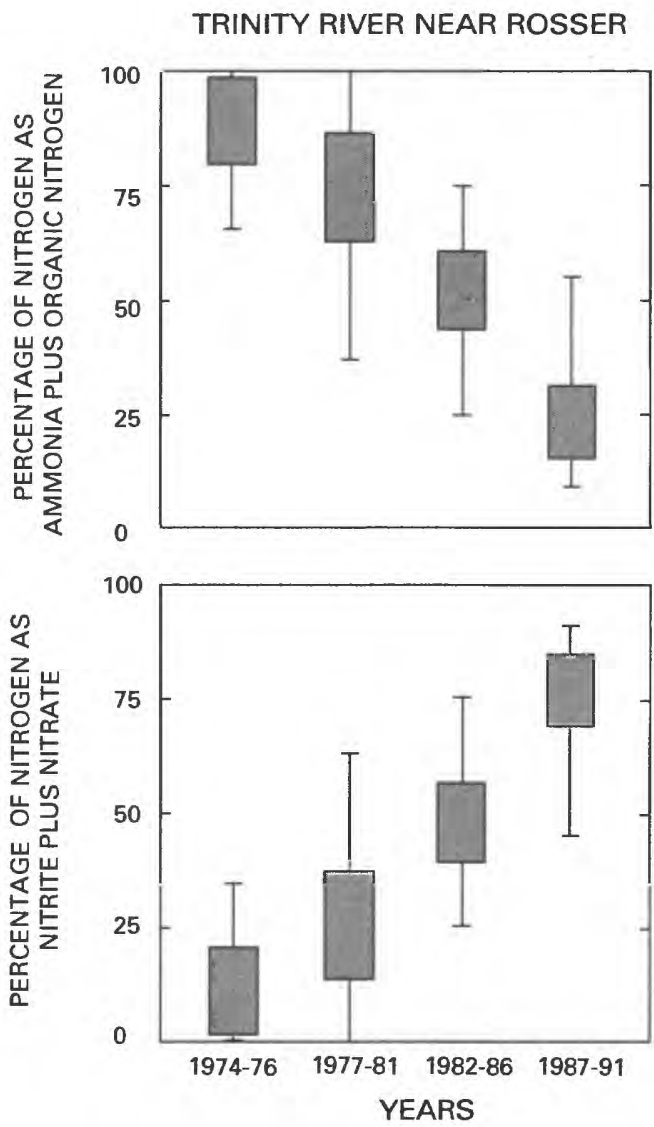

TRINITY RIVER BELOW DALLAS
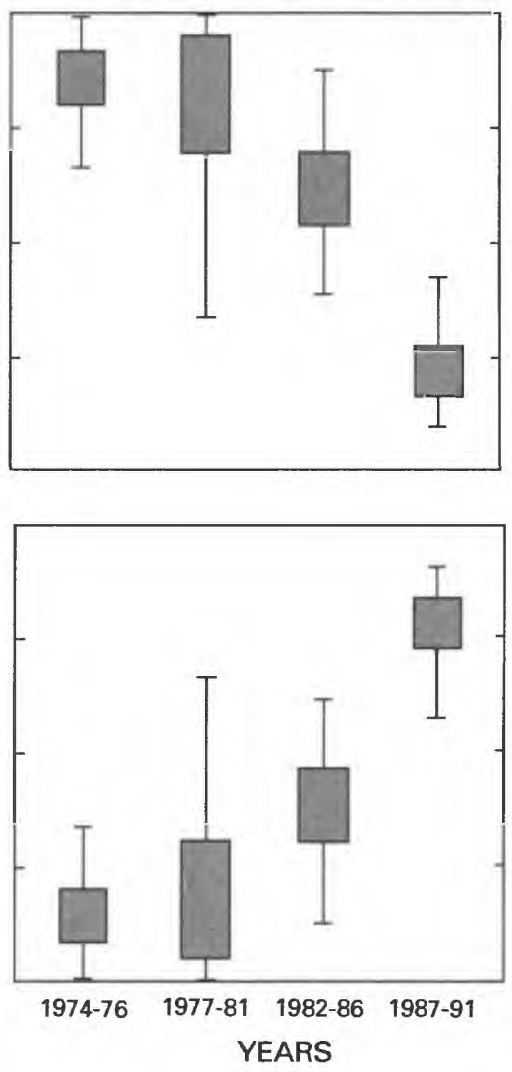

Figure 35. Change in nitrogen speciation for successive time intervals at sites downstream from wastewater-treatment plants in the Trinity River Basin study unit (modified from Van Metre and Reutter, 1994). 

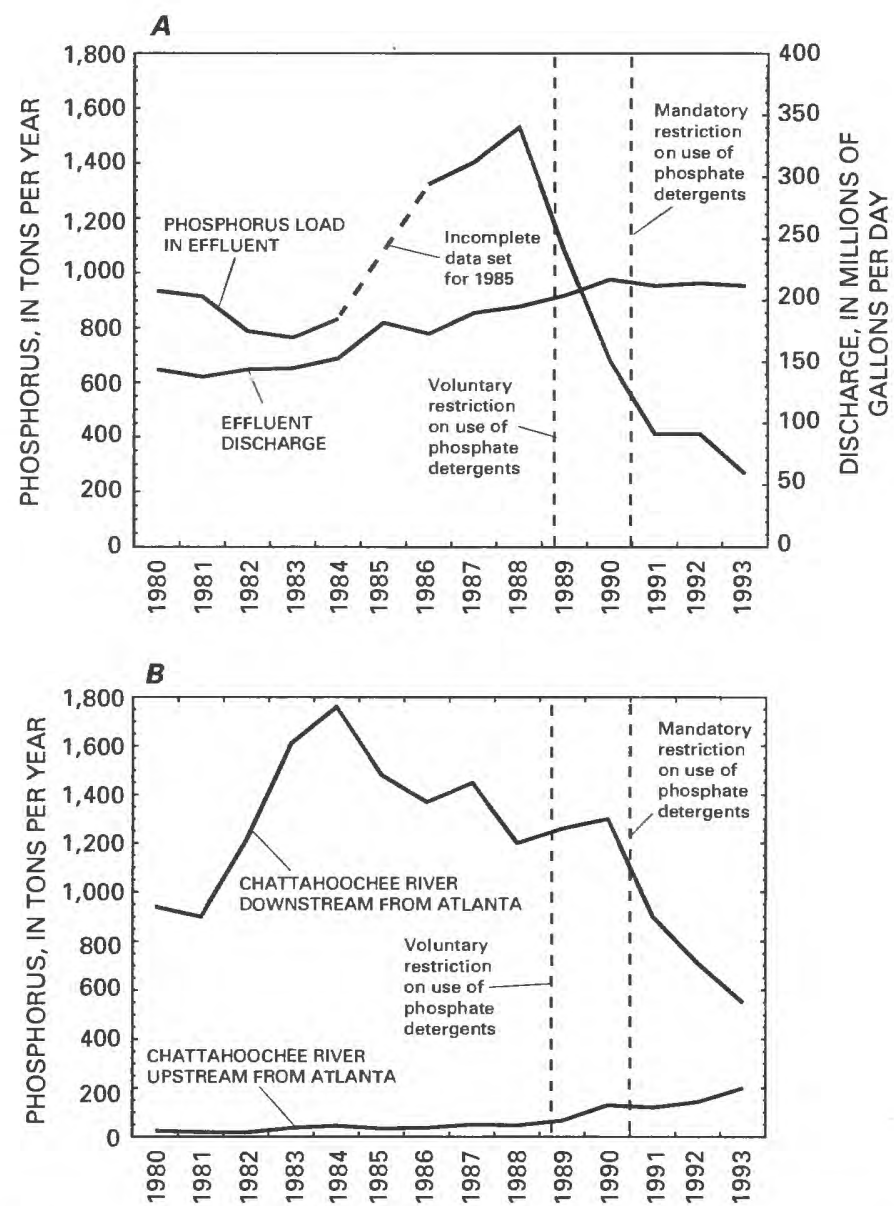

Figure 36. Phosphorus loads in (A) wastewater-treatment plant effluent, and (B) the Chattahoochee River before and after restrictions on the use of phosphate detergents were mandated (from Wangsness and others, 1994). 

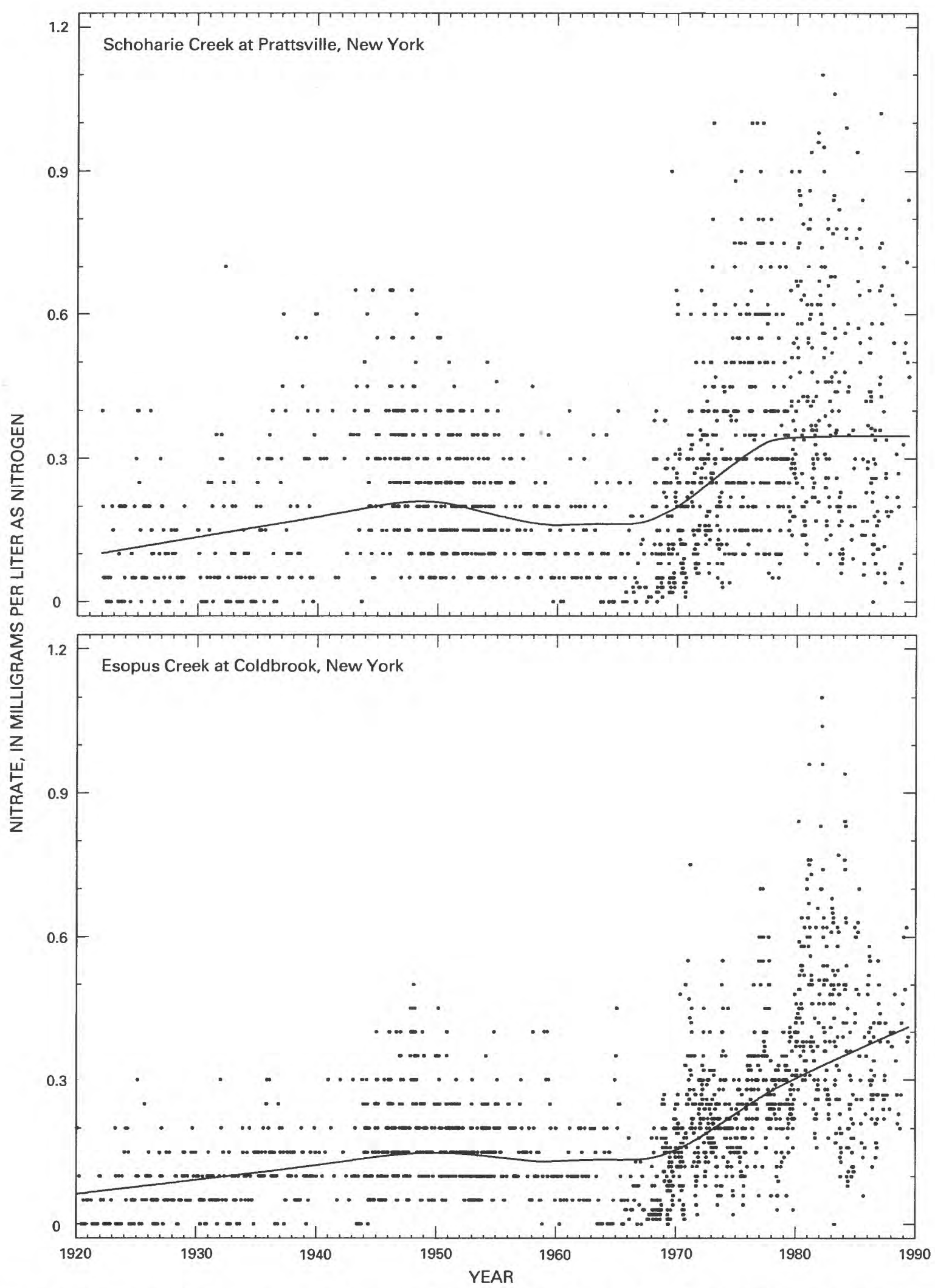

Figure 37. Trends in nitrate concentration at sites downstream from forested areas in the Hudson River Basin study unit (from Murdoch and Stoddard, 1992). 


\section{Spatial Distribution of Nutrient Concentrations in Surface Water}

Regional and national analyses of nutrients in surface water were accomplished using the national retrospective data set, compiled from the 20 NAWQA study units (tables 6 and 7). The objectives of these analyses were confined to comparisons of nutrient concentrations for groups of sites in relation to general land-use factors in the upstream drainage basins. Comparisons among individual sites and evaluation of trends were not made because of inconsistencies in sampling frequencies, periods of record, and chemical analyses.

Boxplots of ammonia, nitrate, and total phosphorus concentrations from all sites categorized by dominant land use are shown in figure 38. Ammonia and total phosphorus concentrations from Urban sites were significantly higher than concentrations from sites in any other land-use setting. Nitrate concentrations from Agricultural, Urban, and Agricultural/Urban sites were not significantly different from each other but were higher than concentrations from other sites. Concentrations of all three nutrients from Undeveloped sites were significantly lower than those from anthropogenically affected sites. These Undeveloped-site data might be representative of background concentrations of nutrients within the 20 NAWQA study units.

In samples from Undeveloped sites, 90 percent of the ammonia concentrations were less than $0.1 \mathrm{mg} / \mathrm{L}$. This concentration was exceeded in at least 50 percent of samples from Urban and Urban/ Undeveloped sites and in more than 25 percent of samples from Agricultural and Agricultural/Urban sites. Ammonia concentrations greater than $0.1 \mathrm{mg} / \mathrm{L}$ might be considered evidence of anthropogenic effects upstream from surface-water sites in the 20 NAWQA study units. Concentrations exceeded $0.2 \mathrm{mg} / \mathrm{L}$ in fewer than 25 percent of samples from Agricultural sites but in more than 50 percent of samples from Urban sites. Ammonia in excess of this concentration might indicate effects from urban land use.

Ammonia concentrations in more than 10 percent of the samples from Urban sites exceeded $2.1 \mathrm{mg} / \mathrm{L}$ (fig. 38), which is the maximum value of the chronic-exposure criteria within the normal ranges of $\mathrm{pH}$ and temperature found in natural surface water (U.S. Environmental Protection Agency, 1986). The minimum criterion is $0.07 \mathrm{mg} / \mathrm{L}$, at $\mathrm{pH} 9.0$ and $30^{\circ} \mathrm{C}$. Ammonia concentrations in less than 25 percent of the samples from Undeveloped sites exceeded this value. This evidence indicates that naturally occurring concentrations of ammonia generally are not a problem, but concentrations often can exceed criteria downstream from urban areas.

In samples from Undeveloped sites, about 90 percent of the nitrate concentrations were less than $0.7 \mathrm{mg} / \mathrm{L}$. Concentrations in more than 50 percent of the samples from Agricultural, Agricultural/Urban, and Urban sites were greater than $0.7 \mathrm{mg} / \mathrm{L}$. Nitrate concentrations exceeding this value might be considered evidence of anthropogenic effects upstream from surface-water sites in the 20 NAWQA study units.

Concentrations of nitrate in more than 90 percent of samples from all land-use settings were less than one-half the drinking-water MCL (10 mg/L, fig. 38). The MCL was exceeded in slightly less than 1 percent of the samples from Agricultural sites, mostly in samples from one site in the San Joaquin study unit. This site was on an agricultural-drainage channel, and nitrate concentrations in every sample exceeded the MCL. The MCL was exceeded in at least one sample from 7 (of 113) Agricultural and Agricultural/Urban sites. In samples from Urban sites, the MCL was exceeded only seven times at 5 (of 34 ) sites, all in the Dallas-Fort Worth area of the Trinity study unit. Overall, nitrate concentrations in surface-water samples from the study units were low. Concentrations were significantly higher downstream from agricultural and urban land-use settings but generally were less than the MCL.

In samples from Undeveloped sites, 90 percent of the total phosphorus concentrations were less than $0.1 \mathrm{mg} / \mathrm{L}$. This concentration was exceeded in more than 50 percent of samples from sites in all other landuse settings except Agricultural/Undeveloped. Total phosphorus concentrations greater than $0.1 \mathrm{mg} / \mathrm{L}$ might be considered evidence of anthropogenic effects upstream from surface-water sampling sites in the 20 NAWQA study units. Concentrations exceeded $0.2 \mathrm{mg} / \mathrm{L}$ in less than 25 percent of samples from Agricultural sites, but in more than 50 percent of samples from Urban sites. Total phosphorus in excess of this concentration might indicate effects from urban land use. 

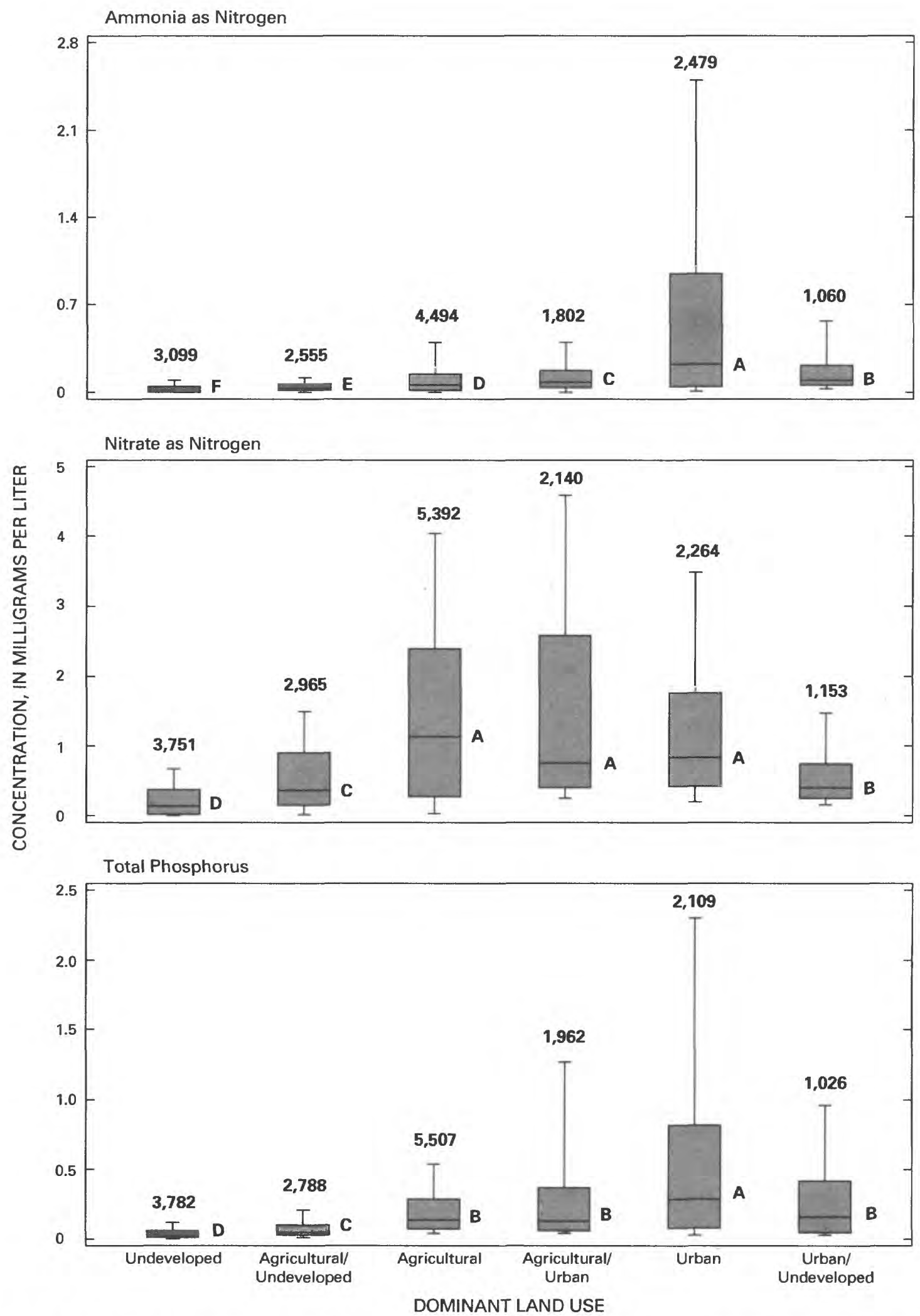

Figure 38. Distributions of ammonia, nitrate, and total phosphorus concentrations in surface water related to upstream land use for samples in the national retrospective data set. 
Total phosphorus concentrations in the national retrospective data set generally exceeded the USEPArecommended limit in streams $(0.1 \mathrm{mg} / \mathrm{L})$ except in samples from Undeveloped and Agricultural/ Undeveloped sites (fig. 38). The highest concentrations were in samples from Urban sites, for which almost 75 percent exceeded this limit. Concentrations were not significantly different among Agricultural, Agricultural/Urban, and Urban/Undeveloped sites. The recommended limit was exceeded in more than 50 percent of samples from these sites. The USEPArecommended maximum concentration of phosphate for discharge into lakes or reservoirs $(0.05 \mathrm{mg} / \mathrm{L})$ was exceeded in more than 25 percent of the samples from Undeveloped sites, about 50 percent of the samples from Agricultural/Undeveloped sites, and about 75 percent of the samples from all other sites. However, this recommendation is for phosphate concentration, whereas the data were for total phosphorus, which includes organic forms and generally would be greater than the concentration of phosphates only. Even taking these differences into consideration, concentrations of total phosphorus in many surface-water samples from the 20 NAWQA study units were high and were significantly elevated downstream from urban land uses.

\section{Variability Within Land-Use Settings}

Data from samples representing individual landuse settings were investigated for regional patterns by comparing sites among selected NAWQA study units. Different groups of study units were chosen for comparisons of data from Undeveloped, Agricultural, and Urban land uses. Selection of study units for analysis of a particular land-use setting was based on the number of sites in the study unit that were classified in that setting. In addition, an effort was made to obtain a broad regional coverage of the United States and to represent different characteristics within each setting. The primary characteristics considered were forest type for Undeveloped sites, crop type for Agricultural sites, and population density for Urban sites.

\section{Undeveloped Land}

The NAWQA study units selected for analysis of nutrient concentrations downstream from Undeveloped land-use conditions are listed in table 16. Undeveloped sites in these study units were defined to be sampling locations downstream from drainage basins where the land uses were predominantly Forest Land, Wetland, or Rangeland. In some cases, data from adjacent study units that had similar forest types were combined to provide an adequate number of sites in that forest type. These combinations were the Connecticut and Hudson data, the Lower Susquehanna and Potomac data, and the San Joaquin and Nevada data that were collected at sites in the Sierra Nevada.

Table 16. National Water-Quality Assessment (NAWQA) Program study units used in national comparisons within various land-use categories and among large drainage basins

[ $x$, data from study unit included in national analysis; --, data not included]

\begin{tabular}{|c|c|c|c|c|}
\hline \multirow{2}{*}{$\begin{array}{l}\text { Study unit } \\
\text { (see figure 1) }\end{array}$} & \multicolumn{3}{|c|}{ Land-use category } & \multirow{2}{*}{$\begin{array}{c}\text { Large } \\
\text { drainage } \\
\text { basins }\end{array}$} \\
\hline & $\begin{array}{l}\text { Undevel- } \\
\text { oped }\end{array}$ & $\begin{array}{l}\text { Agricul- } \\
\text { tural }\end{array}$ & Urban & \\
\hline Albemarle-Pamlico & -- & $\mathrm{X}$ & - & -- \\
\hline Apalachicola & - & - & $\mathrm{X}$ & $\mathrm{X}$ \\
\hline Central Columbia & -- & $X$ & - & - \\
\hline Central Nebraska & - & $\mathrm{X}$ & - & $\mathrm{X}$ \\
\hline Connecticut & $\mathrm{X}$ & - & $\mathrm{X}$ & - \\
\hline Georgia-Florida & $\mathrm{X}$ & $\mathrm{X}$ & - & - \\
\hline Hudson & $\mathrm{X}$ & - & -- & - \\
\hline Lower Susquehanna & $\mathbf{X}$ & $\mathrm{X}$ & - & $\mathrm{X}$ \\
\hline Nevada & $X$ & - & $\mathrm{X}$ & - \\
\hline Ozark & $\mathrm{X}$ & $\mathrm{X}$ & - & $\mathrm{X}$ \\
\hline Potomac & $\mathrm{X}$ & $\mathrm{X}$ & - & $\mathrm{X}$ \\
\hline Red & - & $x$ & - & $\mathrm{X}$ \\
\hline Rio Grande & $\mathrm{X}$ & - & - & $\mathrm{X}$ \\
\hline San Joaquin & $\mathrm{X}$ & $\mathrm{X}$ & - & - \\
\hline South Platte & - & - & $X$ & $\mathrm{X}$ \\
\hline Trinity & - & - & $\mathrm{X}$ & $\mathrm{X}$ \\
\hline Upper Snake & $\mathbf{X}$ & - & - & $\mathrm{X}$ \\
\hline W. Lake Michigan & $\mathrm{X}$ & - & - & - \\
\hline White & - & $X$ & - & $X$ \\
\hline Willamette & -- & - & -- & $\mathrm{X}$ \\
\hline
\end{tabular}


The distributions of ammonia, nitrate, and total phosphorus concentrations from samples collected at Undeveloped land-use sites in the selected study units are shown in figure 39. The distributions of both nitrogen species were highest in the northeastern study units (Connecticut, Hudson, Lower Susquehanna, and Potomac). That part of the Nation is most affected by atmospheric deposition, which could be a major source of nitrate in runoff from forested areas (Smith and others, 1987; Puckett, 1994). The lowest concentrations of both ammonia and nitrate were in the Sierra Nevada (San Joaquin and Nevada). Except in the Northeast, at least 90 percent of the samples had ammonia concentrations less than $0.1 \mathrm{mg} / \mathrm{L}$ and nitrate concentrations less than $0.6 \mathrm{mg} / \mathrm{L}$. These concentrations might be considered general baselines for indicating the absence of significant anthropogenic effects at surface-water sites in the 20 NAWQA study units.

These suggested baseline concentrations closely correspond to the concentrations identified in the comparison of land-use groups as lower limits indicating possible effects from agricultural or urban land uses.

The highest concentrations of total phosphorus were in the Georgia-Florida and Rio Grande study units. In the Georgia-Florida study unit, most of the high concentrations occurred at two sampling sites downstream from geologic phosphate deposits. In the Rio Grande study unit, high phosphorus concentrations were positively correlated to high suspended-sediment concentrations (Anderholm and others, 1994). The lowest concentrations of phosphorus were in the Nevada, Ozark, and W. Lake Michigan study units. In every study unit, 75 percent of the samples had total phosphorus concentrations less than $0.1 \mathrm{mg} / \mathrm{L}$. This concentration might be considered the baseline for total phosphorus at surface-water sites in the 20 NAWQA study units. Concentrations exceeding this value previously were identified as a possible indication of effects from agricultural or urban land uses.

The pattern of nutrient-concentration distributions among study units seems to be related more to regional differences, such as climate, than to vegetation type in the Undeveloped drainage-basin areas. For example, oak-hickory is the major forest type in the Lower Susquehanna and Potomac study units in the Eastern United States and in the Ozark study unit in the Midwest (U.S. Forest Service, 1967). However, nutrient concentrations at Undeveloped sites in the Lower Susquehanna and Potomac study units were more similar to those in the nearby Connecticut and Hudson study units, where the major forest type is maple-beech-birch. In addition, nitrate and phospho- rus concentrations in the Connecticut and Hudson study units were significantly different from those in the W. Lake Michigan study unit, which also contains large areas of maple-beech-birch forest.

\section{Agricultural Land}

The NAWQA study units selected for analysis of nutrient concentrations downstream from Agricultural land-use conditions are listed in table 16. Agricultural sites in these study units were defined to be sampling locations downstream from drainage basins where the land uses were predominantly cropland or pasture. A few sites in the Central Nebraska study unit that were defined to be combinations of Rangeland and more than 50-percent Agricultural Land also were included. Data from the adjacent Lower Susquehanna and Potomac study units were combined to provide an adequate number of sites in the Northeastern United States.

The distributions of ammonia, nitrate, and total phosphorus concentrations from samples collected at Agricultural land-use sites in the selected study units are shown in figure 40. Median concentrations of ammonia were significantly higher in samples from the Albemarle-Pamlico and Central Nebraska study units. In all other study units, at least 50 percent of the concentrations were less than the baseline concentration of ammonia $(0.1 \mathrm{mg} / \mathrm{L})$ identified in analysis of data from Undeveloped sites. Most concentrations were well below even the lowest criterion for a possible un-ionized-ammonia hazard $(0.07 \mathrm{mg} / \mathrm{L}$ at $\mathrm{pH} 9$ and $30^{\circ} \mathrm{C}$; U.S. Environmental Protection Agency, 1986). Concentrations were lowest in samples from the Ozark, White, and Central Columbia study units.

In contrast to ammonia, the median concentrations of nitrate were highest in the White and Central Columbia study units. Concentrations were slightly lower in the Lower Susquehanna, Potomac, and Central Nebraska study units but still were significantly higher than those in the other study units. Nitrate was less than the standard $(10 \mathrm{mg} / \mathrm{L})$ in more than 90 percent of samples from all study units, and the standard was exceeded only in samples from the Lower Susquehanna, Georgia-Florida, White, and San Joaquin study units. The high concentrations in the Georgia-Florida study unit were unusual; nitrate in almost 75 percent of the samples was less than the baseline concentration $(0.6 \mathrm{mg} / \mathrm{L})$ identified from the Undeveloped-site data. In all other study units except the Red, this baseline was exceeded in at least 50 percent of the samples. 

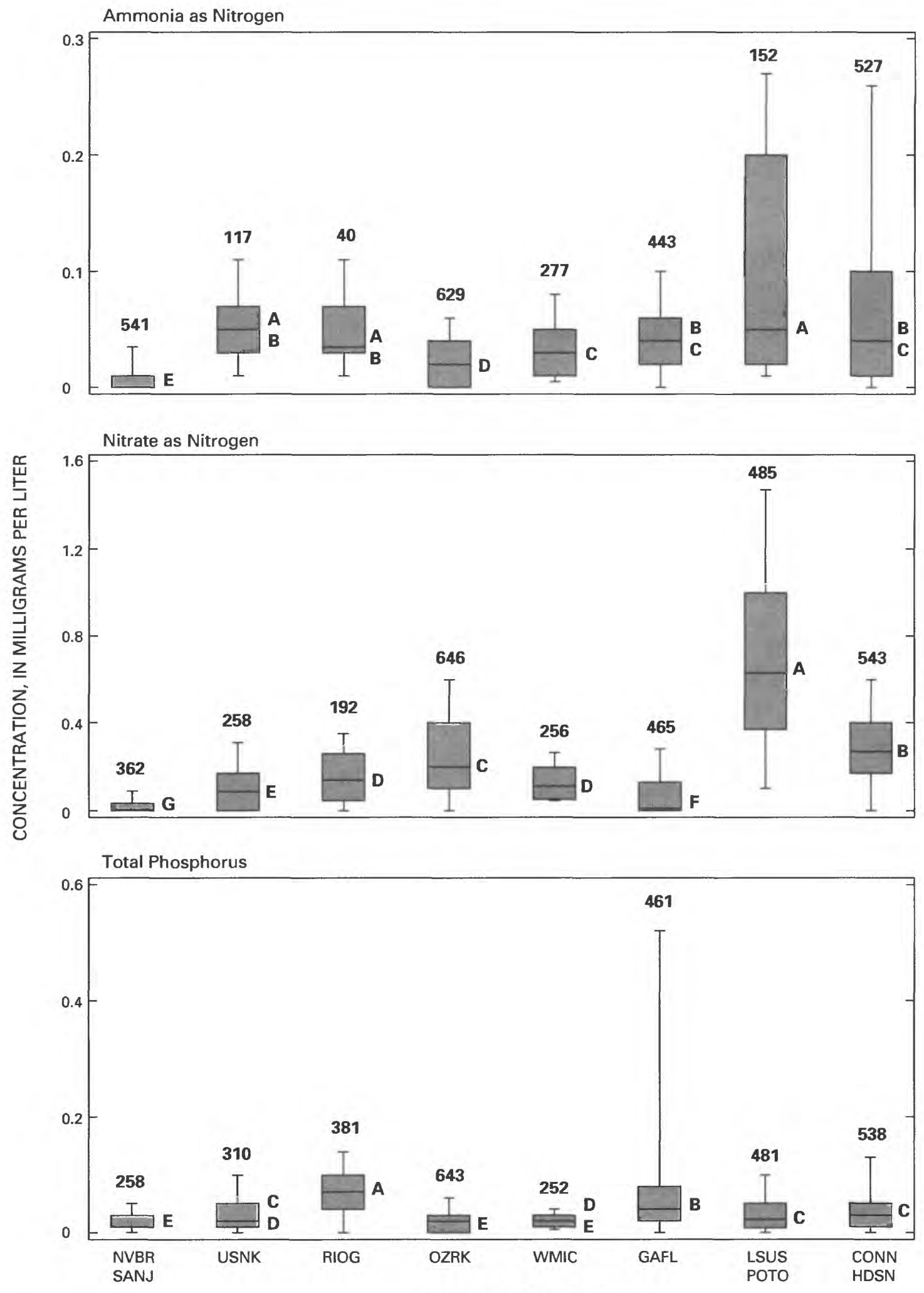

NAWOA STUDY UNIT

Figure 39. Distributions of ammonia, nitrate, and total phosphorus concentrations in surface water draining undeveloped areas in selected NAWQA study units for samples in the national retrospective data set (see figure 1 for study-unit location). 

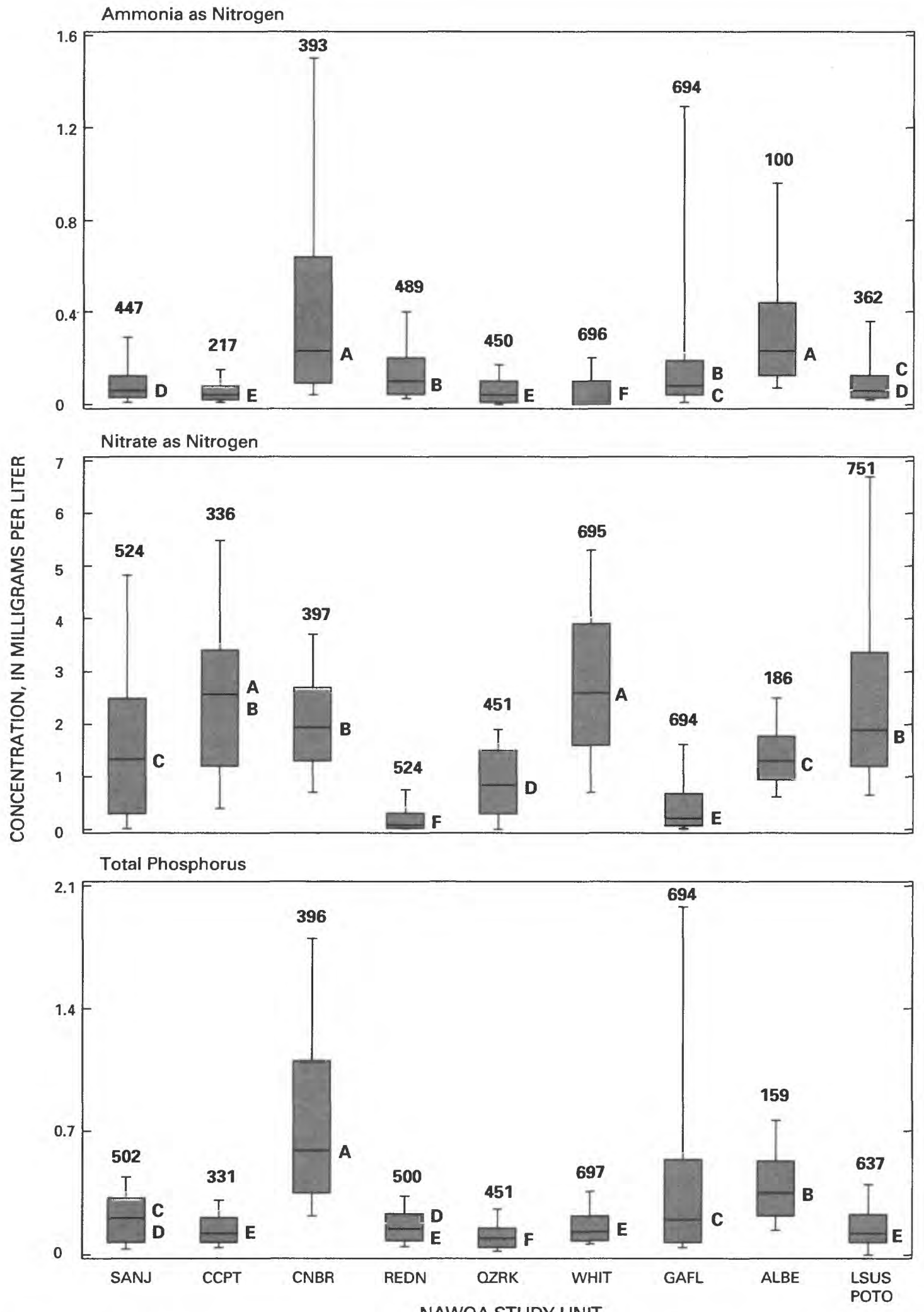

Figure 40. Distributions of ammonia, nitrate, and total phosphorus concentrations in surface water draining agricultural areas in selected NAWQA study units for samples in the national retrospective data set (see figure 1 for study-unit location). 
The pattern of total phosphorus concentrations relative to study units was similar to that of ammonia. Median concentrations were highest in the Central Nebraska and Albemarle-Pamlico study units. The median was significantly lower for the Georgia-Florida study unit, but a large number of samples had high concentrations. Total phosphorus concentrations in samples from all other study units generally were low, with only about 50 percent exceeding the baseline $(0.1 \mathrm{mg} / \mathrm{L})$ identified from the Undeveloped-site data.

No obvious correlations were found between the distributions of nutrient concentrations at Agricultural sites and drainage-basin characteristics that might explain the differences in these distributions among the study units. Regional factors, such as climate, do not appear to have an effect because differences in nutrient distributions were significant between study units in similar areas of the Nation and insignificant between study units in different regional settings. For example, nitrate concentrations in samples from the Lower Susquehanna and Potomac study units in Pennsylvania and Maryland were less similar to those in samples from the nearby Albemarle-Pamlico study unit in Virginia and North Carolina than they were to those in samples from the Central Nebraska study unit in Nebraska. Neither can these patterns be explained by similarities or differences in crop type. Corn is the primary crop grown in each of these four study units (U.S. Bureau of the Census, 1989), yet the distribution of nitrate concentrations in samples from the Albemarle-Pamlico study unit was more similar to that in samples from the San Joaquin study unit, where the primary crops are cotton, fruits, and vegetables. Also, the distributions of nitrate concentrations in samples from the two primary wheat-producing study units, the Central Columbia and Red, were very different, but the distribution in samples from the Central Columbia study unit was quite similar to those from several of the corn-producing study units (Lower Susquehanna, Potomac, White, and Central Nebraska).

The relations of nutrient concentrations to individual drainage-basin characteristics were investigated by using nonparametric correlation analysis (Helsel and Hirsch, 1992, p. 210-218). This technique identifies monotonic, although not necessarily linear, correlation. Multiple variable analyses were not undertaken because of inconsistencies in the availability of data among study units. Drainage-basin characteristics that could be defined from data provided by most of the study units were various land uses, as a percentage of total area, and population density. In addition, the area- weighted average soil hydrologic group was computed for each basin for which data were available from digital maps prepared by the U.S. Soil Conservation Service (1993). Correlation coefficients for these basin characteristics with ammonia, nitrate, and total phosphorus are listed in table 17. Although many of the correlations were statistically significant, most were too small to indicate any important relations. The greatest coefficient was for the positive correlation of nitrate with urban area, indicating that agricultural effects might be compounded by urban effects in areas of mixed land use. The negative correlation of nitrate with wetland area also was large, indicating that wetlands might buffer the effects of nutrient runoff from agricultural land. Possible buffering mechanisms might be uptake or retention of nutrients in wetlands or denitrification due to anoxic conditions in wetland soils, as discussed in the ground-water sections of this report.

Table 17. Spearman correlation coefficients between selected drainage-basin characteristics and nutrient concentrations at sites downstream from agricultural land use

$[--$, coefficient is not significant at $p<0.05]$

\begin{tabular}{lccc}
\hline \multirow{2}{*}{$\begin{array}{c}\text { Drainage-basin } \\
\text { characteristic }\end{array}$} & Ammonia & Nitrate & $\begin{array}{c}\text { Total } \\
\text { phosphorus }\end{array}$ \\
\cline { 2 - 4 } & -- & 0.17 & 0.16 \\
\hline $\begin{array}{c}\text { Agricultural area, } \\
\text { percent }\end{array}$ & 0.04 & -- & -0.10 \\
$\begin{array}{c}\text { Forested area, } \\
\text { percent } \\
\text { Urban area, } \\
\text { percent } \\
\text { Wetland area, } \\
\text { percent }\end{array}$ & -0.04 & 0.56 & 0.06 \\
$\begin{array}{c}\text { Soil hydrologic } \\
\text { group }\end{array}$ & -0.21 & -0.53 & 0.12 \\
$\begin{array}{c}\text { Population density, } \\
\text { per square mile }\end{array}$ & -0.31 & -- & -0.18 \\
\hline
\end{tabular}

\section{Urban Land}

The NAWQA study units selected for analysis of nutrient concentrations downstream from Urban landuse conditions are listed in table 16. Urban sites in these study units were defined to be sampling locations downstream from drainage basins that were predominantly urban or built up. A few sites in the Connecticut and Apalachicola study units that were defined to be 
combinations of Forest Land and more than 20 percent Urban Land also were included. All sites in the Connecticut study were located in the urban corridor between Hartford, Connecticut, and New York City. Sites in the Apalachicola study unit were in the Atlanta area. Sites in the Trinity study unit were in the Dallas-Fort Worth area. Sites in the South Platte study unit were downstream from Denver or the nearby communities of Loveland or Fort Collins in Colorado. Ammonia and nitrate data were available only from the Loveland and Fort Collins sites. One site in the Nevada area was downstream from Las Vegas and was analyzed separately from the remaining sites, which were in the Reno and Lake Tahoe areas.

The distributions of ammonia, nitrate, and total phosphorus concentrations from samples collected at Urban land-use sites in the selected study units are shown in figure 41. By far, the highest ammonia concentrations occurred at the Las Vegas site. The concentration in every sample from this site was high enough to exceed all the national criteria for un-ionized ammonia, regardless of $\mathrm{pH}$ and temperature. This site receives effluent from the Las Vegas wastewatertreatment plant, and because the background flow is low, there is little dilution of the effluent. Concentrations of ammonia were lower in samples from all other study units. However, concentrations in about 75 percent of the samples from each study unit were greater than the baseline concentration of ammonia $(0.1 \mathrm{mg} / \mathrm{L})$ identified in analysis of data from Undeveloped sites. Concentrations in more than 25 percent of the samples from the Connecticut and Trinity study units could exceed the un-ionized ammonia criteria if $\mathrm{pH}$ was greater than 7.5 and temperature was greater than $15^{\circ} \mathrm{C}$. In the Apalachicola study unit and in the Reno and Lake Tahoe areas of the Nevada study unit, concentrations in less than 10 percent of the samples could exceed the criteria, and only if $\mathrm{pH}$ was greater than 8 and temperature was greater than $25^{\circ} \mathrm{C}$.

The median concentration of nitrate was highest in samples downstream from the Trinity study unit but was not significantly different from the median in samples from the South Platte study unit. Concentrations in more than 75 percent of the samples from the Connecticut, Trinity, and South Platte study units exceeded the baseline concentration of nitrate $(0.6 \mathrm{mg} / \mathrm{L})$ identified in analysis of data from Undeveloped sites. However, the nitrate standard for drinking water $(10 \mathrm{mg} / \mathrm{L})$ was exceeded only in six samples collected at four sites in the Trinity study unit. Concentrations in less than 50 percent of the samples from the Apalachicola study unit and from the Las Vegas site exceeded the baseline. In samples from the Reno and Lake Tahoe area only 1 of 66 concentrations exceeded the baseline.

The median concentration of total phosphorus also was highest in samples from the Trinity study unit but was not significantly different from medians in samples from the South Platte study unit or the Las Vegas site. Data from the South Platte study unit were for dissolved orthophosphate rather than total phosphorus concentrations. No total phosphorus analyses were available for Urban sites in this study unit. The orthophosphate analyses were for samples collected downstream from the Denver wastewatertreatment plant, where this species is typically about 80 percent of the total phosphorus concentration, based on data collected by the South Platte project (D.W. Litke, U.S. Geological Survey, oral commun., 1994). In more than 95 percent of the samples from the Trinity, South Platte, and Las Vegas sites, total phosphorus exceeded the baseline concentration $(0.1 \mathrm{mg} / \mathrm{L})$ identified in analysis of data from Undeveloped sites. This baseline value is equal to the maximum concentration of total phosphorus recommended for protection from eutrophication; therefore, concentrations at Urban sites in these study units usually were high enough that excessive algal growth could be a risk. Median concentrations of total phosphorus were significantly lower in samples from the Connecticut and Apalachicola study units, but concentrations still exceeded the baseline in about 75 percent of samples. In samples from the Reno and Lake Tahoe areas, only about 25 percent of the samples contained total phosphorus in excess of the baseline concentration.

Monotonic correlation coefficients between nutrient concentrations in samples from Urban sites and either population or land-use factors were all too small to indicate any important relations; however, the correlations with population factors might have been unfavorably influenced by the lack of uniformity in the population data. For example, population density was skewed toward values less than 500 people per square mile. Correlations with streamflow also were inconclusive, although high concentrations generally occurred during low flow, and concentrations were consistently low at any site when flow exceeded $10,000 \mathrm{ft}^{3} / \mathrm{s}$. This result indicates that the urban effect on nutrient concentrations becomes diluted at higher flows. 

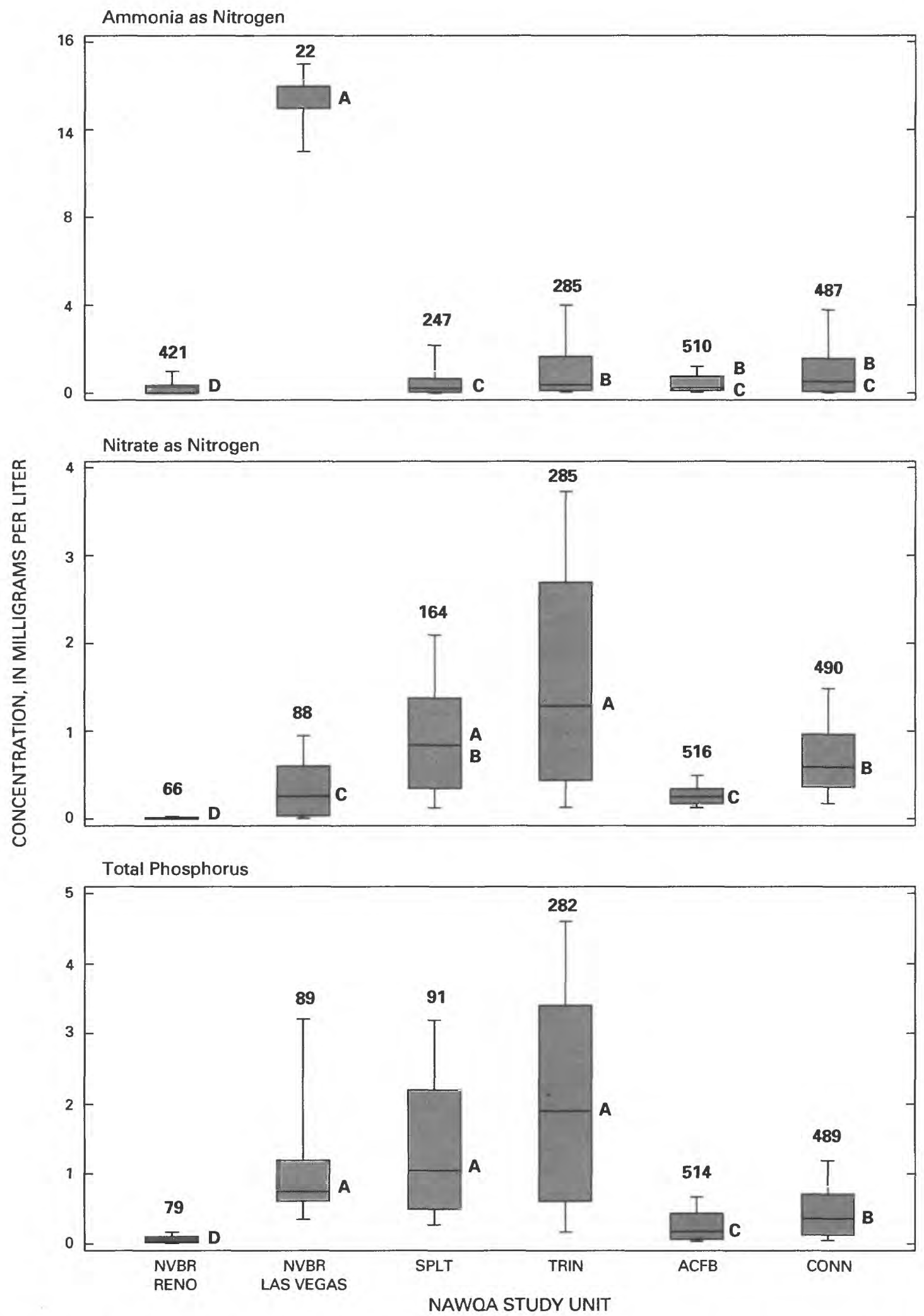

Figure 41. Distributions of ammonia, nitrate, and total phosphorus concentrations in surface water draining urban areas in selected NAWQA study units for samples in the national retrospective data set (see figure 1 for study-unit location). 
Variability Among Large Drainage Basins

Samples collected at locations with upstream drainage areas greater than 10,000 square miles were considered to be affected by multiple land uses. Surface-water chemistry at these locations is an integration of many upstream influences, including point sources, ground-water inflow, and variable amounts of runoff from different areas in the drainage basin. Some locations also are affected by storage in, and releases from, upstream reservoirs. These locations are referred to as Large-Integrator sites. The NAWQA study units that had an adequate number of samples from such sites are listed in table 16. The distributions of ammonia, nitrate, and total phosphorus concentrations collected at Large-Integrator sites in these study units are shown in figure 42 .

In general, the concentrations of all three nutrient species were lower than those at sites predominantly affected by either agricultural or urban land use. This result might be caused by dilution due to multiple sources of inflow. Dilution also provides a possible explanation for the differences in ammonia concentrations among samples from different study units (fig. 42). The highest concentrations were in samples from the Red, South Platte, Central Nebraska, and Rio Grande study units. These same study units had the lowest median streamflows (fig. 43) and, therefore, the least potential for dilution. In the other study units, where streamflows were higher, ammonia concentrations in at least 75 percent of the samples were less than the baseline concentration $(0.1 \mathrm{mg} / \mathrm{L})$ identified in analysis of data from Undeveloped sites. Any effects of agricultural and urban land uses upstream from the Large-Integrator sites in these study units appear to be diminished, probably by dilution.

The pattern of nitrate distributions among study units is more complex (fig. 42). The highest median concentrations were in samples from the White and South Platte study units. Agricultural land use in the White study unit might be so extensive that the effect of dilution from other sources of inflow is diminished.
The distribution of nitrate concentrations in samples from Large-Integrator sites in the White study unit was almost identical to the distribution in samples from Agricultural sites (fig. 40). Likewise, the distribution of nitrate concentrations in samples from LargeIntegrator sites in the South Platte study unit was similar to the distribution in samples from Urban sites (fig. 41), although the cause is more likely lack of dilution due to low streamflow. Median concentrations of nitrate also were high in the Lower Susquehanna, Potomac, Trinity, and Central Nebraska study units. In each of these study units, concentrations were high in samples from Agricultural or Urban sites (figs. 40 and 41 ). In addition, nitrate in samples from the Lower Susquehanna and Potomac study units might be affected by atmospheric deposition, as indicated by high nitrate concentrations at Undeveloped sites (fig. 39).

The distributions of total phosphorus concentrations in samples from Large-Integrator sites seems to have a regional pattern (fig. 42). In study units in the eastern and far western parts of the Nation, concentrations generally were lower than the baseline $(0.1 \mathrm{mg} / \mathrm{L})$ identified in analysis of data from Undeveloped sites. In study units in the central part of the Nation, except for the Ozark study unit, concentrations were generally higher than the baseline. This pattern might be related to higher dilution flow in the East and West or to higher suspended-sediment concentrations, which potentially transport more total phosphorus, in the Central United States. Data on suspended-sediment concentrations at the Large-Integrator sites were insufficient to analyze for a possible correlation.

Another regional pattern that is apparent in the Large-Integrator site data is the similarity between the Lower Susquehanna and Potomac study units. No significant differences were detected for median concentrations of any nutrient species. This result supports the combination of these two study units in analysis of the data from Undeveloped and Agricultural sites. 

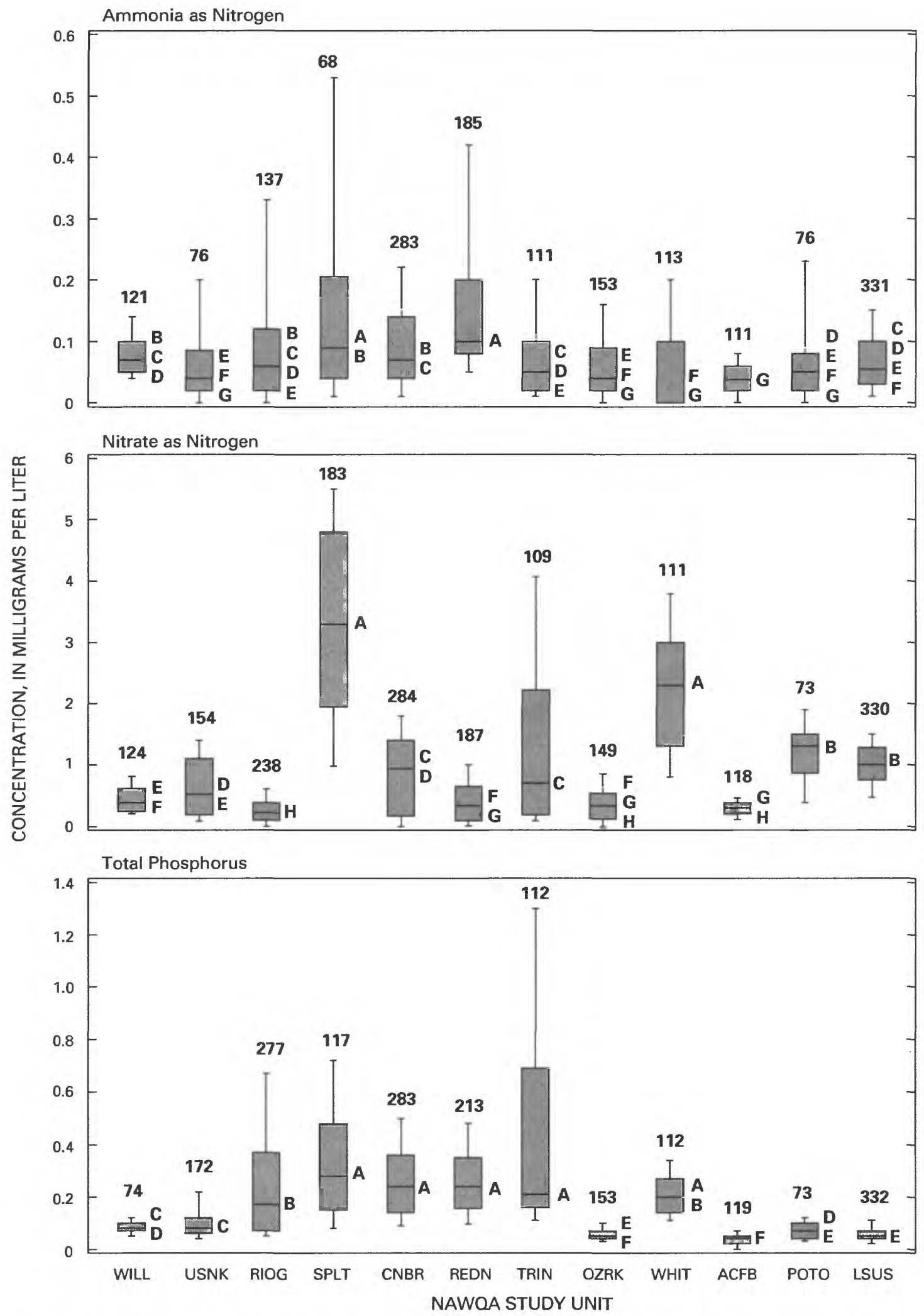

Figure 42. Distributions of ammonia, nitrate, and total phosphorus concentrations in surface water draining large basins in selected NAWQA study units for samples in the national retrospective data set (see figure 1 for study-unit location). 


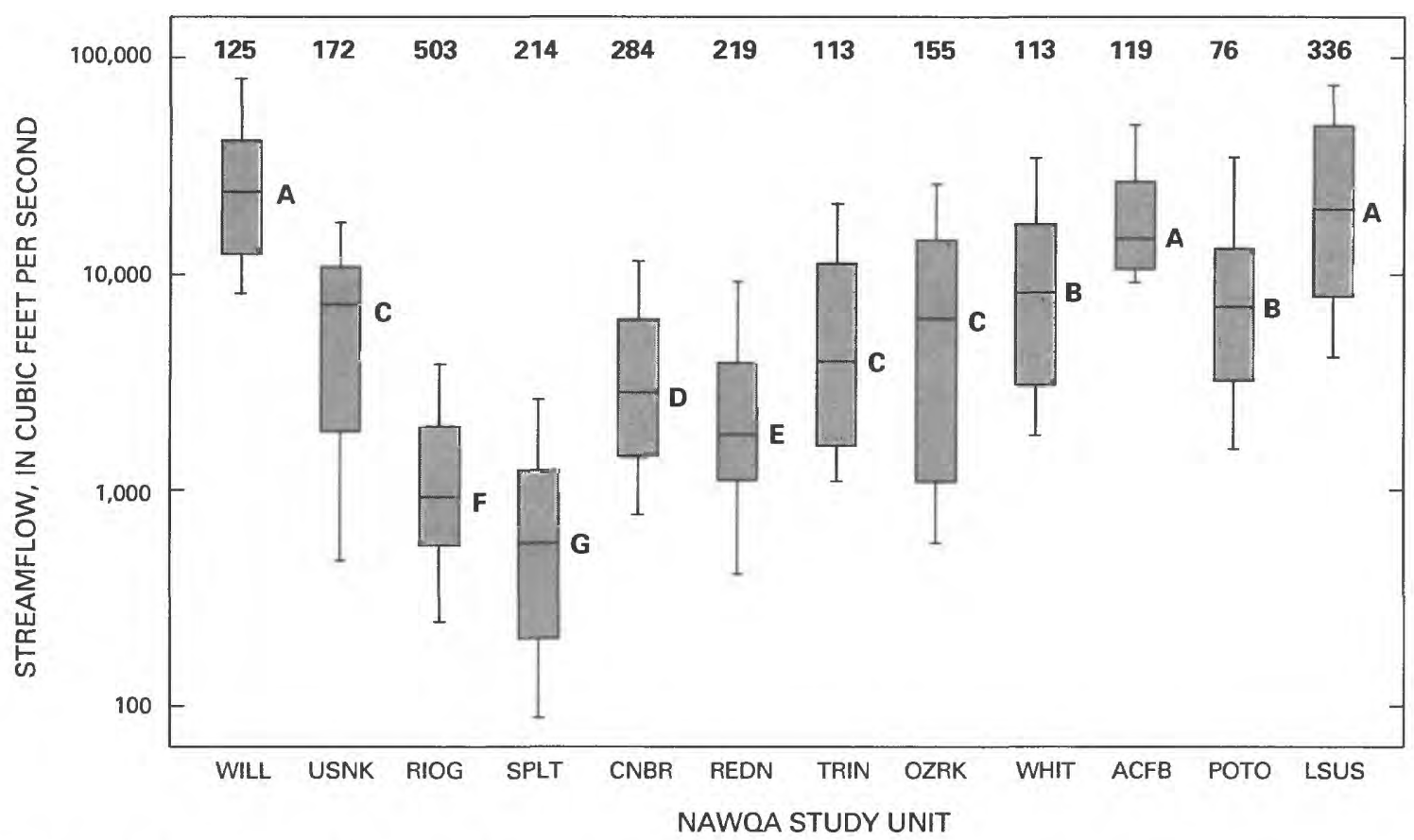

Figure 43. Distribution of streamflow at the time of sampling at sites downstream from large basins in selected NAWQA study units for samples in the national retrospective data set (see figure 1 for studyunit location).

\section{RELATION BETWEEN NITRATE CONCENTRATIONS IN GROUND WATER AND SURFACE WATER IN AGRICULTURAL AREAS}

Direct comparison of nutrient concentrations in ground water and surface water is limited using the national retrospective data sets because the sample collection was not designed for this purpose. However, a regional comparison illustrates some general patterns that deserve additional analysis as the NAWQA Program progresses. A regional pattern of nitrate concentrations in agricultural areas is shown in figure 44 . Median concentrations are plotted for each NAWQA study unit that had sufficient surface- and ground-water data. The study units are arranged generally from the Northeast on the right side of the figure to the West Coast on the left side.

Several regional patterns are apparent on figure 44. High concentrations in ground water occur in parts of the Northeast (Lower Susquehanna and Potomac), the West (Central Nebraska and South Platte), and along the West Coast (Central Columbia, Willamette, and San Joaquin). This was previously shown in the section on regional analysis of groundwater data. In general, these study units also have high concentrations in surface water, particularly the Lower
Susquehanna, Central Nebraska, South Platte, and Central Columbia. The surface-water nitrate concentrations in the Willamette study unit were conspicuously low in relation to other study units in the West Coast area. Also, surface- and ground-water nitrate concentrations in the Connecticut study unit were lower than in other Northeastern study units.

Ground-water and surface-water nitrate concentrations generally were low throughout the Southeast and Midwest study units (AlbemarlePamlico, Georgia-Florida, Apalachicola, White, W. Lake Michigan, Red, Ozark, and Trinity). As was pointed out in the previous discussion of regional distribution of nitrate in ground water, soil and hydrogeologic characteristics of these parts of the Nation favor denitrification, which might limit nitrate concentrations. The sole exception was high concentrations in surface water in the White study unit. Agricultural areas in that study unit are extensively tile-drained, which diverts seepage from the ground water and provides a quick path for nutrient-rich runoff to reach surface streams.

Nitrate concentrations also were low in surface and ground water in the Nevada study unit. This area is quite arid, and irrigation is not as extensive as in some other Western study units. The sources of nitrate are limited. 


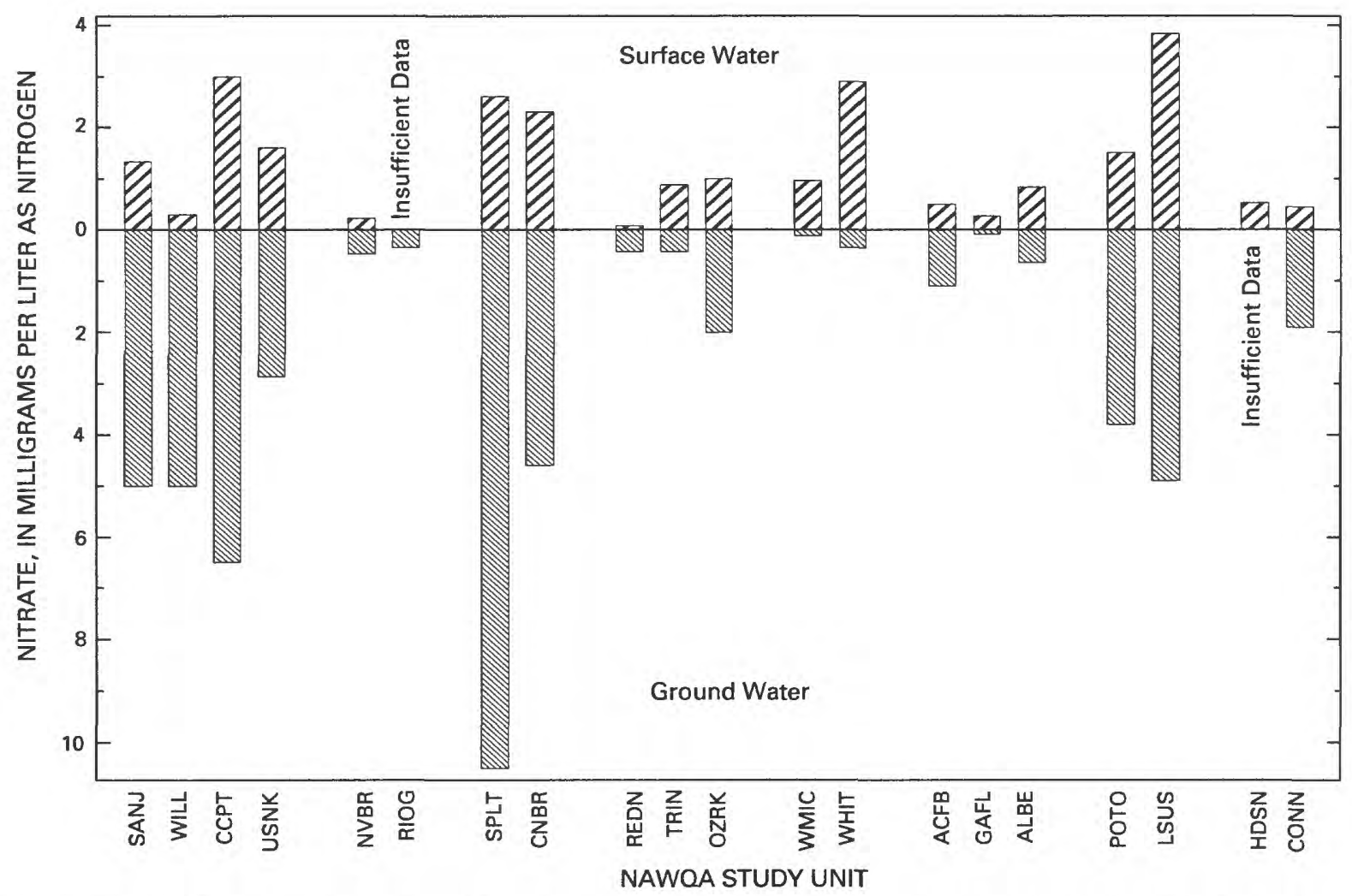

Figure 44. Median nitrate concentrations in ground water and surface water from selected NAWQA study units (see figure 1 for study-unit location).

\section{IMPLICATIONS FOR MANAGEMENT OF WATER RESOURCES}

High concentrations of nutrients in ground-water and surface-water samples in the national retrospective data sets generally were associated with specific land uses. Nitrate concentrations in ground water were elevated primarily in agricultural areas. Concentrations were highest in shallow ground water, less than 100 feet below land surface. Because of the time involved for ground water to move vertically in some areas, the full effect of the current nitrogen availability might not be noted in some aquifers for many years. Likewise, the effects of implementing management practices to improve water quality might not be evident for a number of years.

Nitrate concentrations also were elevated in surface water downstream from agricultural areas but were lower than those in ground water. A variety of regional and local factors, such as soil and geologic characteristics, can affect nitrate concentrations and the partitioning of nitrate between ground and surface waters. Regional patterns and the distribution of local characteristics could be useful in identifying areas of potential nitrate problems.

Nitrate concentrations exceed the MCL for drinking water in about 21 percent of the wells that tap the upper 100 feet below land surface. Nitrate does not pose a health risk for residents who drink water from deeper confined and bedrock aquifers. Generally, nitrate in ground water is a greater concern in rural domestic-supply wells than in urban public-supply wells. Public-supply wells commonly are completed in deeper parts of the ground-water system where contaminants are not as prevalent. Also, public-supply wells generally have high-capacity pumps that draw ground water from a larger vertical interval than do domestic-supply wells, which increases the potential for dilution of contaminants that generally occur near the top of the aquifer. Nitrate concentrations exceeded 
the MCL in only about 1 percent of the sampled public-supply wells, mostly in agricultural areas of the Midwestern and Northwestern United States. Concentrations in surface-water samples rarely exceeded the MCL.

Elevated concentrations of ammonia and phosphorus in surface water occur primarily downstream from urban areas. Because these nutrients are of concern for aquatic life rather than for human consumption, data on concentrations in ground water are limited. Concentrations in surface water were high enough to warrant concerns about toxicity to fish and accelerated eutrophication in many parts of the Nation. Recent improvements in wastewater treatment have decreased ammonia concentrations downstream from some urban areas, but the result has been an increase in nitrate concentrations. This condition limits the direct threat of toxicity but does not change the potential for eutrophication.

Information on environmental factors that affect water quality is useful to quickly and efficiently identify drainage basins throughout the Nation with the greatest vulnerability for nutrient contamination and to delineate areas where ground-water or surface-water contamination is most likely to occur. Determining where water-quality problems are most likely to occur is the key to devising appropriate watershedmanagement strategies. Although watershed management is ultimately done on individual drainage basins, these findings imply that management strategies need to incorporate some flexibility in different regions of the Nation. For example, watershed management of surface water, rather than ground water, might be a priority in the Corn Belt because of intercepted tile drainage. Watershed management in the Southeast, where abundant rainfall, highly organic soils, ditching, and lush vegetation can remediate nitrate loading to ground water, generally will be different than watershed management in parts of the Northeast, Midwest, and West, where ground water is more vulnerable to nitrate contamination. Understanding the regional distribution and key environmental factors that affect nutrient concentrations in ground water and surface water is critical to implementing and evaluating Federal, State, and local programs designed to manage and protect our water resources.

\section{REFERENCES}

Alexander, R.B., and Smith, R.A., 1990, County level estimates of nitrogen and phosphorus fertilizer use in the United States, 1945 to 1985: U.S. Geological Survey Open-File Report 90-130, 12 p.

Anderholm, S.K., Radell, M.J., and Richey, S.F., 1994, Water-quality assessment of the Rio Grande Valley study unit, Colorado, New Mexico, and TexasAnalysis of selected nutrient, suspended sediment, and pesticide data: U.S. Geological Survey WaterResources Investigations Report 94 4061, 203 p.

Anderson, J.R., Hardy, E.E., Roach, J.T., and Witmer, R.E., 1976, A land use and land cover classification system for use with remote sensor data: U.S. Geological Survey Professional Paper 964, 28 p.

Berndt, M.P., in press, Ground-water quality assessment of the Georgia-Florida coastal plain study unitAnalysis of available information on nutrients: U.S. Geological Survey Water-Resources Investigations Report 95-4039.

Bonn, B.A., Hinkle, S.R., Wentz, D.A., and Uhrich, M.A., in press, Analysis of nutrient and ancillary water-quality data for surface and ground water of the Willamette Basin, Oregon, 1980-90: U.S. Geological Survey Water-Resources Investigations Report 95-4036.

Bormann, F.H., Likens, G.E., Fisher, D.W., and Pierce, R.S., 1968, Nutrient loss accelerated by clear-cutting of a forest ecosystem: Science, v. 159, p. 882-884.

Burkart, M.R., and Kolpin, D.W., 1993, Hydrologic and land-use factors associated with herbicides and nitrate in near-surface aquifers: Journal of Environmental Quality, v. 22, no. 4, p. 646-656.

Chen, Hsiu-Hsiung, and Druliner, A.D., 1987, Nonpointsource agricultural chemicals in ground water in Nebraska-Preliminary results for six areas of the High Plains Aquifer: U.S. Geological Survey WaterResources Investigations Report 86-4338, 68 p.

Clark, G.M., 1994, Assessment of selected constituents in surface water of the upper Snake River Basin, Idaho and western Wyoming, water years 1975-89: U.S. Geological Survey Water-Resources Investigations Report 93-4229, 49 p.

Conover, W.J., and Iman, R.L., 1981, Rank transformation as a bridge between parametric and nonparametric statistics: The American Statistician, v. 35, no. 3, p. 124-129.

Davis, J.V., Petersen, J.C., Adamski, J.C., and Freiwald, D.A., in press, Water-quality assessment of the Ozark Plateaus study unit, Arkansas, Kansas, Missouri, and Oklahoma-Analysis of information on nutrients, suspended sediment, and suspended solids for 1970-92: U.S. Geological Survey Water-Resources Investigations Report 95-4042. 
Dennehy, K.F., Litke, D.W., McMahon, P.B., Tate, C.M., and Heiny, J.S., 1994, Water-quality assessment of the South Platte River Basin, Colorado, Nebraska, and Wyoming-Analysis of available nutrient, suspendedsediment, and pesticide data, water years 1980-92: U.S. Geological Survey Water-Resources Investigations Report 94-4095, 145 p.

Dierberg, F.E., 1991, Non-point source loadings of nutrients and dissolved organic carbon from an agriculturalsuburban watershed in east central Florida: Water Research, v. 25 , no. 4, p. 363-374.

Eckhardt, D.A., Flipse, W.J., Jr., and Oaksford, E.T., 1989, Relation between land use and ground-water quality in the upper glacial aquifer in Nassau and Suffolk counties, Long Island, New York: U.S. Geological Survey Water-Resources Investigations Report 86-4142, 35 p.

Edmondson, W.T., and Lehman, J.T., 1981, The effect of changes in the nutrient income on the condition of Lake Washington: Limnology and Oceanography, v. 26 , no. 1, p. 1-29.

Exner, M.E., 1985, Concentration of nitrate-nitrogen in groundwater, Central Platte Region, Nebraska, 1984: Lincoln, University of Nebraska, Conservation and Survey Division, Institute of Agriculture and Natural Resources, 1 p. (map).

Exner, M.E., and Spalding, R.F., 1976, Groundwater quality of the Central Platte Region, 1974: Lincoln, University of Nebraska, Conservation and Survey Division Resource Atlas 2, Institute of Agriculture and Natural Resources, 48 p. 1990, Occurrence of pesticides and nitrate in Nebraska's ground water: Lincoln, University of Nebraska, Water Center Publication 1, Institute of Agriculture and Natural Resources, $34 \mathrm{p}$.

Fan, A.M., Willhite, C.C., and Book, S.A., 1987, Evaluation of the nitrate drinking water standard with reference to infant methemoglobinemia and potential reproductive toxicity: Regulatory Toxicology and Pharmacology, v. 7, p. 135-148.

Fegeas, R.G., Claire, R.W., Guptill, S.C., Anderson, K.E., and Hallam, C.A., 1983, Land use and land cover digital data: U.S. Geological Survey Circular 895-E, 21 p.

Fishel, D.K., Brown, M.J., Kostelnik, K.M., and Howse, M.A., 1993, Evaluation of agricultural bestmanagement practices in the Conestoga River headwaters, Pennsylvania--Description and water quality of the Little Conestoga Creek headwaters prior to the implementation of nutrient management: U.S. Geological Survey Water-Resources Investigations Report 90-4131, 68 p.

Greene, K.E., Ebbert, J.C., and Munn, M.D., 1994, Nutrients, suspended sediment, and pesticides in streams and irrigation systems in the Central Columbia Plateau in Washington and Idaho, 1959-1991:
U.S. Geological Survey Water-Resources Investigations Report 94-4215.

Hager, S.W., and Schemel, L.E., 1992, Sources of nitrogen and phosphorus to northern San Francisco Bay: Estuaries, v. 15, no. 1, p. 40-52.

Hallberg, G.R., 1989, Nitrate in ground water in the United States, in Follet, R.F., ed., Nitrogen management and ground-water protection: New York, Elsevier Science Publishing Co., p. 35-74.

Hallberg, G.R., and Keeney, D.R., 1993, Nitrate, in Alley, W.M., ed., Regional ground-water quality: New York, Van Nostrand Publishing Co., p. 297-322.

Hamilton, P.A., and Shedlock, R.J., 1992, Are fertilizers and pesticides in the ground water?: U.S. Geological Survey Circular 1080, $16 \mathrm{p}$.

Hamilton, P.A., Denver, J.M., Phillips, P.J., and Shedlock, R.J., 1993a, Water-quality assessment of the Delmarva Peninsula, Delaware, Maryland, and Virginia-Effects of agricultural activities on, and distribution of, nitrate and other inorganic constituents in the surficial aquifer: U.S. Geological Survey Open-File Report 93-40, 95 p.

Hamilton, P.A., Welch, A.H., Christenson, S.C., and Alley, W.M., 1993b, Uses and limitations of existing groundwater-quality data, in Alley, W.M., ed., Regional ground-water quality: New York, Van Nostrand Publishing Co., p. 613-622.

Harned, D.A., McMahon, Gerard, Spruill, T.B., and Woodside, M.D., in press, Water-quality assessment of the Albemarle-Pamlico drainage basin, North Carolina and Virginia - Summary of water-quality data for suspended sediment, nutrients, and pesticides: U.S. Geological Survey Open-File Report 95-191.

Helgesen, J.O., Zelt, R.B., and Stamer, J.K., 1994, Nitrogen and phosphorus in water as related to environmental setting in Nebraska: Water Resources Bulletin, v. 30, no. 5, p. 809-822.

Helsel, D.R., and Hirsch, R.M., 1992, Statistical methods in water resources: Amsterdam, Elsevier, 522 p.

Hem, J.D., 1985, Study and interpretations of the chemical characteristics of natural water ( $3 d$ ed.): U.S. Geological Survey Water-Supply Paper 2254, 263 p.

Hubbard, R.K., and Sheridan, J.M., 1989, Nitrate movement to groundwater in the southeastern coastal plain: Journal of Soil Water Conservation, v. 44, p. 20-27.

Iman, R.L., and Conover, W.J., 1983, A modern approach to statistics: New York, John Wiley, 497 p.

Jaworski, N.A., Groffman, P.M., Keller, A.A., and Prager, J.C., 1992, A watershed nitrogen and phosphorus balance-The upper Potomac River basin: Estuaries, v. 15 , no. 1, p. $83-95$.

Johnson, C.J., and Kross, B.C., 1990, Continuing importance of nitrate contamination of groundwater and wells in rural areas: American Journal of Industrial Medicine, v. 18, p. 449-456. 
Jones, J.L., and Wagner, R.J., in press, Water-quality assessment of the Central Columbia Plateau in Washington and Idaho-Analysis of available nutrient and pesticide data for ground water, 1942-1992: U.S. Geological Survey Water-Resources Investigations Report 94-4258.

Kellogg, R.L., Maizel, M.S., and Goss, D.W., 1992, Agricultural chemical use and ground water quality-Where are the potential problem areas?: U.S. Department of Agriculture, Soil Conservation Service, 41 p.

Kolpin, D.W., Burkart, M.R., and Thurman, E.M., 1994, Herbicides and nitrate in near-surface aquifers in the midcontinental United States: U.S. Geological Survey Water-Supply Paper 2413, $34 \mathrm{p}$.

Kross, B.C., Hallberg, G.R., Bruner, D.R., Libra, R.D., Rex, K.D., and 16 others, 1990, The Iowa state-wide rural well-water survey, water-quality data-Initial analysis: Iowa City, Technology Information Series 19, Iowa Department of Natural Resources, 142 p.

Leahy, P.P., Rosenshein, J.S., and Knopman, D.S., 1990, Implementation plan for the National Water-Quality Assessment Program: U.S. Geological Survey OpenFile Report 90-174, 10 p.

Lee, L.K., and Nielsen, E.G., 1989, Farm chemicals and groundwater contamination, in Nelson, J.R., and McTernan, E.M., eds., Agriculture and ground water quality-Examining the issues: Stillwater, Oklahoma State University, University Center for Water Research, p. 2-10.

Madison, R.J., and Brunett, J.O., 1985, Overview of the occurrence of nitrate in ground water of the United States, in National water summary 1984 -Hydrologic events, selected water-quality trends, and ground-water resources: U.S. Geological Survey Water-Supply Paper 2275, p. 93-105.

McKenna, D.P., and Keefer, D.A., 1991, Potential for agricultural chemical contamination of aquifers in Illinois: Illinois State Geological Survey, Open File Series 1991-7R, $16 \mathrm{p}$.

Mossbarger, W.A., and Yost, R.W., 1989, Effects of irrigated agriculture on groundwater quality in Corn Belt and Lake States: Journal of Irrigation and Drainage Engineering, v. 115, no. 5, p. 773-790.

Murdoch, P.S., and Stoddard, J.L., 1992, The role of nitrate in the acidification of streams in the Catskill Mountains of New York: Water Resources Research, v. 28, no. 10, p. 2707-2720.

Omernik, J.M., 1977, Nonpoint source-stream nutrient level relationships - A nationwide study: Corvallis, Oreg., U.S. Environmental Protection Agency EPA-600/3-P77-105, $151 \mathrm{p}$.

Power, J.F., and Schepers, J.S., 1989, Nitrate contamination of groundwater in North America: Agriculture, Ecosystems and Environment, v. 26, p. 165-187.
Puckett, L.J., 1994, Nonpoint and point sources of nitrogen in major watersheds of the United States: U.S. Geological Survey Water-Resources Investigations Report $94-4001,9$ p.

Richards, R.P., Baker, D.B., and Wallrabenstein, L.K., 1991, Nitrate concentrations in Ohio's private water supplies, in Surface and groundwater quality - Pollution prevention, remediation, and the Great Lakes: Bethesda, Md., American Water Resources Association Technical Publication TPS $-91-1$, p. 67-76.

Robertson, F.N., 1979, Evaluation of nitrate in ground water in the Delaware Coastal Plain: Ground Water, v. 17, no. 4, p. $328-337$.

Rosensteel, B.A., and Strom, P.F., 1991, River phosphorus dynamics and reservoir eutrophication potential: Water Resources Bulletin, v. 27, no. 6, p. 957-965.

Rupert, M.G., 1994, Assessment of nutrients and organic compounds in ground water in the upper Snake River Basin, Idaho and western Wyoming-Analysis of available data, 1980-91: U.S. Geological Survey Water-Resources Investigations Report 94-4135, 40 p.

SAS Institute, 1990, SAS/STAT user's guide (version 6, 4th ed.): Cary, N.C., SAS Institute Inc., 2 vol., 1,686 p.

Smith, R.A., Alexander, R.B., and Lanfear, K.J., 1993, Stream water quality in the conterminous United States - Status and trends of selected indicators during the 1980's, in Paulson, R.W., Chase, E.B., Williams, J.S., and Moody, D.W., comps., National water summary 1990-91-Hydrologic events and stream water quality: U.S. Geological Survey Water-Supply Paper 2400, $590 \mathrm{p}$.

Smith, R.A., Alexander, R.B., and Wolman, M.G., 1987, Water-quality trends in the Nation's rivers: Science, v. 235 , p. $1607-1615$.

Solley, W.B., Chase, E.B., and Mann, W.B., IV, 1983, Estimated use of water in the United States in 1980: U.S. Geological Survey Circular 1001, $56 \mathrm{p}$.

Spalding, R.F., and Exner, M.E., 1991, Nitrate contamination in the contiguous United States: Berlin, SpringerVerlag, NATO ASI Series, v. G 30, p. 12-48. 1993, Occurrence of nitrate in groundwater: Journal of Environmental Quality, v. 22, no. 3, p. 392-402.

Stottlemyer, Robert, and Troendle, C.A., 1992, Nutrient concentration patterns in streams draining alpine and subalpine catchments, Fraser Experimental Forest, Colorado: Journal of Hydrology, v. 140, p. 179-208.

Stullken, L.E., Stamer, J.K., and Carr, J.E., 1987, Reconnaissance of water quality in the High Plains Aquifer beneath agricultural lands, south-central Kansas: U.S. Geological Survey Water-Resources Investigations Report 87-4003, 25 p.

Tornes, L.H., and Brigham, M.E., 1994, Nutrients, suspended sediment, and pesticides in waters of the Red River of the North basin, Minnesota, North Dakota, and 
South Dakota, 1970-90: U.S. Geological Survey

Water-Resources Investigations Report 93-4231, 62 p.

U.S. Bureau of the Census, 1989, Census of agriculture 1987-Final county file: Data Users Services Division, Washington, D.C.

1990, Census of population and housing, 1990:

Washington, D.C., U.S. Department of Commerce, Data Users Services Division.

U.S. Department of Agriculture, 1988, Agricultural chartbook: U.S. Department of Agriculture Handbook 673, Washington, D.C., 110 p.

U.S. Environmental Protection Agency, 1983, Results of the nationwide urban runoff program - Volume I - final report: Washington, D.C., Water Planning Division, $186 \mathrm{p}$.

1986, Quality criteria for water 1986: Washington, D.C., U.S. Environmental Protection Agency Report 440/5-86-001, Office of Water [variously paged]. 1990a, County-level fertilizer sales data: PM-2221, Washington, D.C., Office of Policy, Planning, and Evaluation.

1990b, Maximum contaminant levels (subpart B of 141 , National primary drinking water regulations) (revised July 1, 1990): U.S. Code of Federal Regulations, Title 40, Parts 100-149, p. 559-563.

$1990 \mathrm{c}$, National survey of pesticides in drinking water wells, Phase I report: Washington, D.C., U.S. Environmental Protection Agency Report 570/9-90-015, Office of Water, Office of Pesticides and Toxic Substances, $98 \mathrm{p}$. 1990d, Environmental investments-The cost of a clean environment: Washington, D.C., U.S. Environmental Protection Agency Report EPA-230-11-90-083, Office of Policy, Planning, and Evaluation, 478 p.

U.S. Forest Service, 1967, Major forest types, in U.S Geological Survey, 1970, National atlas of the United States of America: Washington, D.C., U.S. Geological Survey, p. 154-155.

U.S. Soil Conservation Service, 1993, State soil geographic data base (STATSGO)-Data users guide: Miscellaneous Publication Number 1492, 88 p.

1994, National Soils Survey Handbook: U.S. Department of Agriculture, Washington, D.C.

Van Metre, P.C., and Reutter, D.C., 1994, Water-quality assessment of the Trinity River Basin, Texas-Analysis of available information on nutrients and suspended sediments, 1974-91: U.S. Geological Survey WaterResources Investigations Report 94-4086, 72 p.

Wangsness, D.J., Frick, E.A., Buell, G.R., and DeVivo, J.C., 1994, Effect of the restricted use of phosphate detergent and upgraded wastewater-treatment facilities on water quality in the Chattahoochee River near Atlanta, Georgia: U.S. Geological Survey Open-File Report 94-99, 4 p.

Zelt, R.B., and Jordan, P.R., 1993, Water-quality assessment of the central Nebraska basins - Summary of data for recent conditions through 1990: U.S. Geological Survey Open-File Report 93-422, 179 p. 


\section{APPENDIX}




\begin{tabular}{|c|c|c|c|}
\hline $\begin{array}{l}\text { Study unit or } \\
\text { area name }\end{array}$ & $\begin{array}{l}\text { Primary author(s) of } \\
\text { retrospective report }\end{array}$ & $\begin{array}{l}\text { U.S. Geological Survey } \\
\text { office address }\end{array}$ & $\begin{array}{l}\text { Electronic mail } \\
\text { address }\end{array}$ \\
\hline Albemarle Pamlico Drainage & Douglas Harned & $\begin{array}{l}3916 \text { Sunset Ridge Road } \\
\text { Raleigh, NC } 27607\end{array}$ & daharned(@)usgs.gov \\
\hline $\begin{array}{l}\text { Apalachicola - Chattahoochee-- } \\
\text { Flint River Basin }\end{array}$ & $\begin{array}{l}\text { Gary Buell } \\
\text { Elizabeth Frick }\end{array}$ & $\begin{array}{l}\text { Peachtree Business Center } \\
\text { Suite } 130 \\
3039 \text { Anıwiler Road } \\
\text { Atlanta, GA 30360-2824 }\end{array}$ & $\begin{array}{l}\text { grbuell@usgs.gov } \\
\text { eafrick(a)usgs.gov }\end{array}$ \\
\hline Central Columbia Plateau & $\begin{array}{l}\text { Karen Greene } \\
\text { Joseph Jones }\end{array}$ & $\begin{array}{l}1201 \text { Pacific Avenue } \\
\text { Suite } 600 \\
\text { Tacoma, WA } 98402\end{array}$ & $\begin{array}{l}\text { kegreene@usgs.gov } \\
\text { jljones@usgs.gov }\end{array}$ \\
\hline Central Nebraska Basins & John Helgesen & $\begin{array}{l}4821 \text { Quail Crest Place } \\
\text { Lawrence, KS } 66049\end{array}$ & jhelge@usgs.gov \\
\hline $\begin{array}{l}\text { Connecticut, Housatonic, and } \\
\text { Thames River Basins }\end{array}$ & $\begin{array}{l}\text { Stephen Grady } \\
\text { Marc Zimmerman }\end{array}$ & $\begin{array}{l}\text { Abraham A. Ribicoff Federal Building } \\
450 \text { Main Street } \\
\text { Room } 525 \\
\text { Hartford, CT } 06103 \\
28 \text { Lord Road } \\
\text { Suite } 280 \\
\text { Marlborough, MA } 01752\end{array}$ & mzimmerm@usgs.gov \\
\hline Georgia-Florida Coastal Plain & $\begin{array}{l}\text { Marian Berndt } \\
\text { Lisa Ham } \\
\text { Hilda Hatzell }\end{array}$ & $\begin{array}{l}227 \text { North Bronough Street } \\
\text { Suite } 3015 \\
\text { Tallahassee, FL } 32301\end{array}$ & $\begin{array}{l}\text { mberndt@usgs.gov } \\
\text { lkham@usgs.gov } \\
\text { hhatzell@usgs.gov }\end{array}$ \\
\hline Hudson River Basin & Patrick Phillips & $\begin{array}{l}\text { P.O. Box } 1669 \\
\text { Albany, NY } 12201\end{array}$ & pjphilli@usgs.gov \\
\hline Lower Susquehanna River Basin & Robert Hainly & $\begin{array}{l}840 \text { Market Street } \\
\text { Lemoyne, PA I } 7043-1586\end{array}$ & rahainly@usgs.gov \\
\hline Nevada Basin and Range & $\begin{array}{l}\text { Hugh Bevans } \\
\text { Kathryn Kilroy }\end{array}$ & $\begin{array}{l}333 \text { West Nye Lane } \\
\text { Carson City, NV } 89706\end{array}$ & $\begin{array}{l}\text { hbevans@usgs.gov } \\
\text { kckilroy(a)usgs.gov }\end{array}$ \\
\hline Ozark Plateaus & $\begin{array}{l}\text { James Adamski } \\
\text { Jerri Davis }\end{array}$ & $\begin{array}{l}\text { 401 Hardin Road } \\
\text { Little Rock, AR } 72211 \\
1210 \text { Homelife Plaza } \\
\text { Rolla. MO } 65401\end{array}$ & $\begin{array}{l}\text { jadamski@usgs.gov } \\
\text { jdavis@usgs.gov }\end{array}$ \\
\hline Potomac River Basin & Joel Blomquist & $\begin{array}{l}208 \text { Carroll Building } \\
8600 \text { LaSalle Road } \\
\text { Towson, MD } 21286\end{array}$ & jdblomqu@usgs.gov \\
\hline Red River of the North & $\begin{array}{l}\text { Mark Brigham } \\
\text { Lan Tornes }\end{array}$ & $\begin{array}{l}2280 \text { Woodale Drive } \\
\text { Mounds View, MN 55112-0049 }\end{array}$ & $\begin{array}{l}\text { mbrigham(a) usgs.gov } \\
\text { tornes(a) usgs.gov }\end{array}$ \\
\hline Rio Grande Valley & Scott Anderholm & $\begin{array}{l}4501 \text { Indian School Road, NE } \\
\text { Suite } 200 \\
\text { Albuquerque, NM } 87110-3929\end{array}$ & anderhol(@)usgs.gov \\
\hline San Joaquin-Tulare Basins & $\begin{array}{l}\text { Karen Burow } \\
\text { Charles Kratzer }\end{array}$ & $\begin{array}{l}\text { Room W-2234 Federal Bldg. } \\
2800 \text { Cottage Way } \\
\text { Sacramento, CA } 95825\end{array}$ & $\begin{array}{l}\text { krburow@usgs.gov } \\
\text { ckratzer@usgs.gov }\end{array}$ \\
\hline South Platte River Basin & David Litke & $\begin{array}{l}\text { Denver Federal Center } \\
\text { P.O. Box 25086, MS } 415 \\
\text { Lakewood, CO } 802250046\end{array}$ & dwlitke@usgs.gov \\
\hline Trinity River Basin & Peter Van Metre & $\begin{array}{l}\text { 8011 Cameron Road } \\
\text { Building A } \\
\text { Austin, TX } 78754 \quad 3898\end{array}$ & pcvanmet@usgs.gov \\
\hline Upper Snake River Basin & $\begin{array}{l}\text { Gregory Clark } \\
\text { Michael Rupert }\end{array}$ & $\begin{array}{l}230 \text { Collins Road } \\
\text { Boise, ID } 83702-4520\end{array}$ & $\begin{array}{l}\text { gmclark@usgs.gov } \\
\text { mgrupert@usgs.gov }\end{array}$ \\
\hline Western Lake Michigan Drainages & Dale Robertson & $\begin{array}{l}6417 \text { Normandy Lane } \\
\text { Madison, WI } 53719\end{array}$ & dzrobert@usgs.gov \\
\hline White River Basin & Jeffrey Martin & $\begin{array}{l}5957 \text { Lakeside Boulevard } \\
\text { Indianapolis, IN } 46278\end{array}$ & jdmartin@usgs.gov \\
\hline Willamette Basin & $\begin{array}{l}\text { Bernadine Bonn } \\
\text { Stephen Hinkle }\end{array}$ & $\begin{array}{l}\text { 10615 SE Cherry Blossom Drive } \\
\text { Portland, OR } 97216\end{array}$ & $\begin{array}{l}\text { babonn@usgs.gov } \\
\text { srhinkle@usgs.gov }\end{array}$ \\
\hline
\end{tabular}

